\title{
Violência e masculinidade: uma contribuição psicanalítica aos estudos das relações de gênero
}

Dissertação apresentada no Instituto de Psicologia da Universidade de São Paulo como requisito parcial à obtenção do título de Mestre em Psicologia.

Área de Concentração: Psicologia Social Orientador: Prof. Dr. Nelson da Silva Júnior.

V. 1

São Paulo

2006 
AUTORIZO A REPRODUÇÃO E DIVULGAÇÃO TOTAL OU PARCIAL DESTE TRABALHO, POR QUALQUER MEIO CONVENCIONAL OU ELETRÔNICO, PARA FINS DE ESTUDO E PESQUISA, DESDE QUE CITADA A FONTE.

Catalogação na publicação

Serviço de Biblioteca e Documentação

Instituto de Psicologia da Universidade de São Paulo

Muszkat, Susana.

Violência e masculinidade: uma contribuição psicanalítica aos estudos das relações de gênero / Susana Muszkat; orientador Nelson da Silva Júnior. --São Paulo, 2006.

207 p.

Dissertação (Mestrado - Programa de Pós-Graduação em Psicologia. Área de Concentração: Psicologia Social) - Instituto de Psicologia da Universidade de São Paulo.

1. Violência 2. Gênero 3. Masculinidade 4. Construtivismo 5. Psicanálise I. Título.

HM291 


\section{FOLHA DE APROVAÇÃO}

Susana Muszkat

Violência e masculinidade: uma contribuição psicanalítica aos estudos das relações de gênero.

Dissertação apresentada ao Instituto de Psicologia da Universidade de São Paulo como requisito parcial à obtenção do título de Mestre em Psicologia

Área de Concentração: Psicologia Social.

Aprovado em:

\section{Banca Examinadora.}

Prof. Dr.:

Instituição: Assinatura:

Prof. Dr.:

Instituição: Assinatura:

Prof. Dr.:

Instituição: Assinatura: 


\section{AGRADECIMENTOS}

Agradeço

Ao meu marido, Braulio e minhas filhas Alice, Adriana e Fernanda, pela importância fundamental na minha vida, pela tolerância às horas passadas ao computador, pelo incentivo e amor.

Aos meus pais, Rubens e Malvina e meus irmãos Eduardo e Debora por contribuírem com um clima permanente de estímulos e desafios.

Ao meu orientador, Nelson da Silva Junior, pelo incansável apoio em todas as horas, pelas inúmeras contribuições ao meu trabalho e por criar e manter um grupo de colegas sempre participantes e colaboradores.

Aos professores e colegas que tive nos cursos do pós do IPUSP pela rica troca de idéias e às secretárias Maria Cecília Rodrigues Freitas e Marinalva Almeida Santos Gil, sempre dispostas a ajudar.

Aos meus colegas de grupo de orientação, Lívia Godinho Nery Gomes, Renata Udler Cromberg, Daniel Rodrigues Lírio, Gláucia Faria da Silva, Clarissa Metzger e Flávia Blay Levisky, pelas ricas discussões e apoio e, em especial, agradeço a Marcelo Gustavo Aguilar Calegare pelas imprescindíveis ajudas técnicas e pelos artigos que me indicou, de total relevância para este trabalho.

À Maria Coleta Oliveira, Malvina Muszkat, Sandra Unbehaum, , Rosemeire Brito e Samantha Neves, colegas da pesquisa Nepo/Unicamp e PMFC, pelas valiosas discussões e horas de trabalho conjunto que muito contribuíram para a elaboração das minhas idéias nesta dissertação e no trabalho institucional de maneira geral.

Aos professores de minha banca de qualificação, Belinda Mandelbaum e João Alberto Carvalho pela disponibilidade e cuidado na leitura, pelas contribuições com seus comentários e por partilharem suas teses comigo, fonte de muita inspiração.

Aos meus amigos Tomi Borger e Gabi Feldman pela ajuda nas horas de aperto com o computador e pelo apoio moral.

Aos meus queridos amigos e amigas, de cá e de lá, sem os quais a vida não teria tanta graça.

A todos aqueles da equipe da PMFC que me auxiliaram ou contribuíram de alguma forma com meu trabalho em todos estes anos.

Aos muitos e diferentes homens que participaram dos grupos que coordenei com os quais tanto aprendi. 


\section{RESUMO}

MUSZKAT, S. Violência e masculinidade: uma contribuição psicanalítica aos estudos das relações de gênero. 2006. 207f. Dissertação (Mestrado) - Instituto de Psicologia, Universidade de São Paulo, São Paulo, 2006.

Este trabalho visa enfocar o tema da violência familiar por dois vértices: o primeiro questiona a adoção de uma lógica simples e maniqueísta com a qual as políticas públicas habitualmente enfrentam essa questão, atribuindo valores positivos e negativos à complexa dinâmica das relações conjugais, de modo a polarizar a questão da violência em vítimas e agressores, de forma rígida. Trabalhamos com a hipótese de que os efeitos destas políticas tendem a cristalizar e perpetuar aquilo mesmo que pretendem combater.

O segundo vértice pretende explicitar qual o lugar destinado, ou "imposto simbolicamente”, aos homens, procurando identificar quais os determinantes culturais, sociais e psicológicos organizadores da subjetividade masculina, visando a compreender como os papéis de gênero e as relações resultantes destes são distribuídas, transmitidas e perpetuadas por esses mesmos gêneros.

Para tanto, esta investigação usa do arcabouço teórico psicanalítico para cotejá-lo com estudos das relações de gênero desenvolvidos nas Ciências Sociais e na Antropologia, com o intuito de ampliar a compreensão do modo de transmissão e perpetuação das relações violentas.

Palavras-chave: Violência; Gênero; Masculinidade; Construtivismo; Psicanálise. 


\begin{abstract}
MUSZKAT, S. Masculinity and violence: a psychoanalytic contribution to the studies of gender relations. 2007. 204p. Dissertation (Masters) - Instituto de Psicologia, Universidade de São Paulo, São Paulo, 2006.
\end{abstract}

The objective of this dissertation is to focus on the theme of gender violence under two perspectives: the first one questions a non-complex and dualistic logic commonly adopted by the public policies when dealing with violence practiced in intimate partner relationships, attributing positive and negative values to the complex couple relationship dynamics, hence, polarizing the understanding or such problematic giving it a rigid victim/ perpetrator form. Our hypothesis is that the effects of such kind of policies tend to crystallize and perpetuate that which they intend to eliminate.

The second perspective aims to explicit a place, 'imposed symbolically' on men, with the objective of identifying the cultural, social and psychological factors which can be determining organizers of the male subjectivity, so as to facilitate the understanding of how gender roles and relationships based on such roles are distributed and perpetuated amongst the genders.

In order to study such issues we will make use of the psychoanalytical theory and side it with the most recent studies developed by the Social Sciences and Anthropology, in order to try to offer tools to the comprehension of how these violent behavioral patterns are transmitted and perpetuated.

Key-Words: Violence; Gender; Masculinity; Constructivism; Psychoanalysis. 


\section{SUMÁRIO}

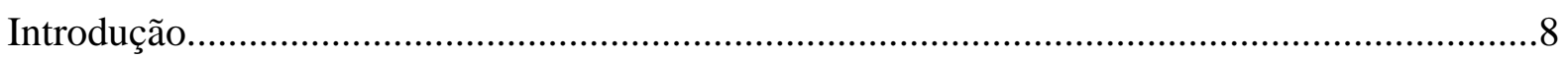

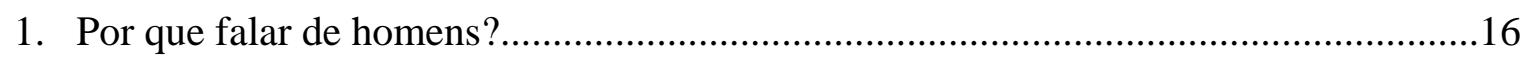

2. O campo construcionista e a violência.........................................................................

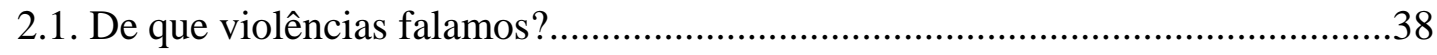

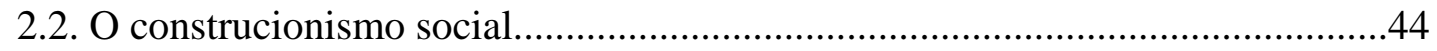

2.3. Gênero, sexo e sexualidade nos estudos de gênero............................................54

2.4. Identidade sexual e identidade de gênero........................................................63

2.5. A cultura na definição de padrões de identidade..............................................68

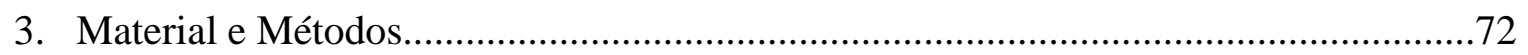

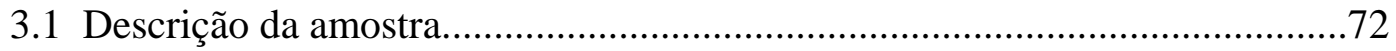

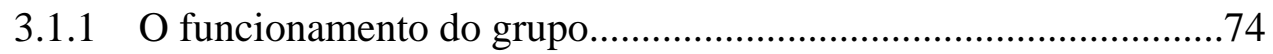

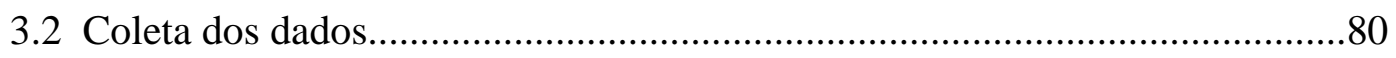

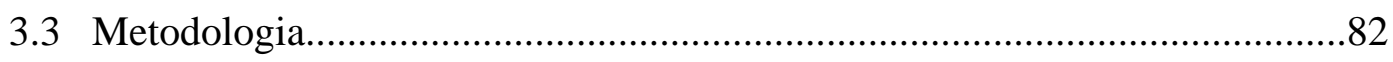

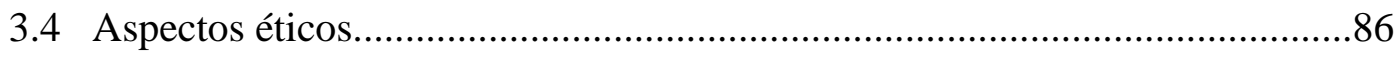

3.5 Quatro sessões dos grupos de reflexão masculina.........................................86

3.5.1 Grupo de 02.04.2004................................................................... 86

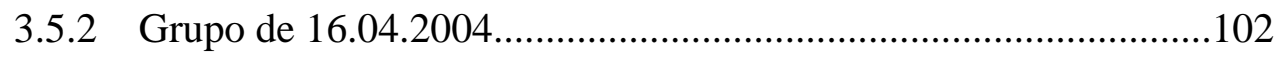

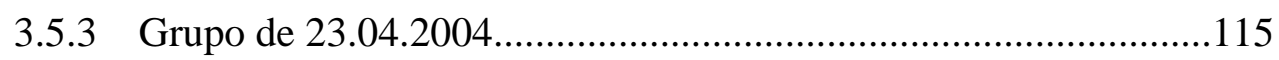

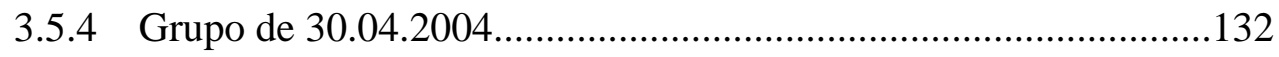

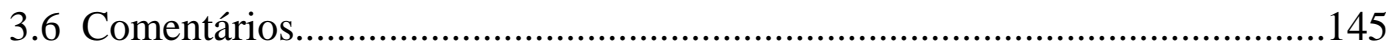

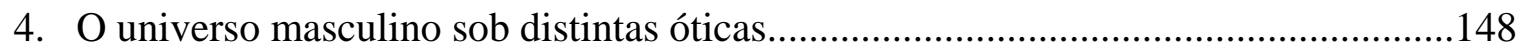

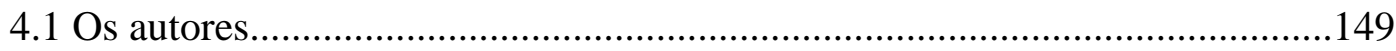




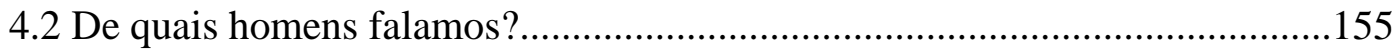

4.3 Contribuiç̧̃̃es psicanalíticas....................................................................160

4.3.1 Identidade e gênero.....................................................................162

4.3.2 O princípio do prazer e a violência de gênero....................................167

4.3.3 O narcisismo e o ideal do ego: a cultura na constituição

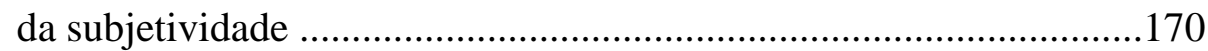

4.3.4 Violência e civilização .....................................................................174

4.3.5 O desamparo, o mundo contemporâneo e a sociedade

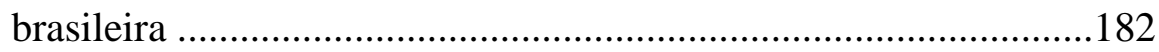

4.3.6 O sadismo e a violência de gênero................................................... 184

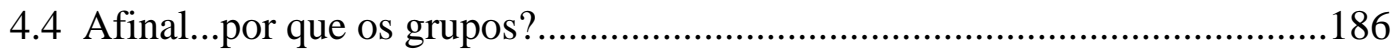

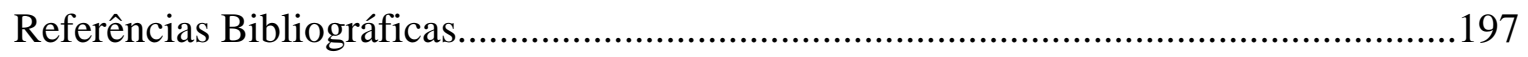

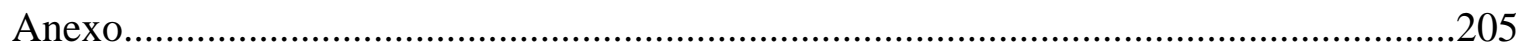




\section{INTRODUÇÃO}

Este projeto tem como seu ponto de partida o trabalho que vem sendo desenvolvido há 12 anos na Organização Não Governamental Pró- Mulher, Família e Cidadania, cujo alvo principal é a atuação junto às famílias de baixa renda do município de São Paulo que estão vivendo em situação de violência, com o intuito de atenuar e prevenir as conseqüências perniciosas deste tipo de relacionamento.

A violência praticada na família é normalmente denominada pelas políticas públicas como violência doméstica, entendida como um tipo de ato praticado principalmente contra mulheres e/ou seus filhos, por seus companheiros e/ou pais respectivamente ${ }^{1}$. Como resultado deste tipo de compreensão, verifica-se uma predominância quase absoluta de programas sociais voltados exclusivamente à proteção de mulheres, crianças e adolescentes, evidenciando uma perspectiva polarizada onde a situação define-se por lados bem definidos de vítimas e agressores.

Levantamentos estatísticos (de janeiro a julho de 2002) de registros de violência nas Delegacias da Mulher do Estado de São Paulo revelam um contingente surpreendente de uma média de 20.000 mulheres maiores de idade e 2.000 mulheres menores vítimas de violência/mês. Ainda assim, as estatísticas são precárias quando se procura obter um real quadro da situação, uma vez que os registros efetuados são em número bastante inferior à verdadeira ocorrência destes atos. Esses dados falam por si e denunciam não só a importância de programas voltados a esta questão quanto revelam a pouca eficácia dos já

\footnotetext{
${ }^{1}$ Em SAFFIOTI, H. Violência Doméstica: questão de polícia e da sociedade. In: CORRÊA, Mariza (org.) Gênero e Cidadania. Campinas: ed. Pagú; Núcleo de Estudos de Gênero-Unicamp, 2001. pág. 59-60, a autora distingue de forma geográfica os termos violência doméstica e violência familiar, sendo a primeira a que se dá no âmbito doméstico e não exclusivamente referente aos membros de uma mesma família, uma vez que agregados não consangüíneos podem coabitar num mesmo local, e a segunda, aquela que se dá contra membros de uma mesma família, não sendo necessariamente dentro do ambiente doméstico.
} 
existentes. O caráter naturalizado da violência, evidenciado não só na experiência prática com a população que atendemos na PMFC, como pelos boletins de ocorrência das DDMs, deve-se principalmente a rígidas crenças calcadas numa ideologia hegemônica masculina, compartilhada tanto por homens como por mulheres, que os aprisionam em papéis prédeterminados e inflexíveis.

Ainda como resultado do caráter de naturalidade, muitas modalidades de violência nem mesmo são reconhecidas como tal, uma vez que simplesmente reproduzem padrões de relacionamento conjugal das famílias de origem. Alvim (2003), em sua dissertação de mestrado, corrobora esta idéia, chamando de 'invisíveis’ este tipo de violência naturalizada e afirmando que, além disto, dados estatísticos comprovam que desde 1980 as mortes violentas constituem o segundo maior índice de óbitos de homens jovens no Brasil, dado verificado também por estudos da Organização Mundial de Saúde em seu relatório anual (2002). Os homens são tanto os principais agentes quanto as principais vítimas de atos violentos. É, portanto, um dado curioso que, no Brasil, programas de ações voltados aos homens, ou que os incluam, sejam tão escassos (no Brasil há apenas cerca de 5 serviços conhecidos, incluindo-se a PMFC), e que a questão da violência que se dá no âmbito familiar tenha como viés principal a exclusão dos homens, sendo estes tratados como vilões que devem ser exclusivamente punidos e isolados. Alvim (2003) argumenta ainda que, além do pouco que se tem feito em nível de políticas públicas, muito pouco tem sido feito no âmbito acadêmico, a fim de interferir com ou alterar tais padrões.

O tema da violência contra a mulher tem sido foco de muitos estudos e não há pouca literatura sobre o assunto. Contudo, como ressaltam Gregori (1993; 2003) e Alvim (2003), estes têm mantido um viés maniqueísta ao privilegiar uma tendência de entender o lugar da mulher como um lugar predominantemente vitimizado, excluindo-a de sua condição de sujeito. De maneira complementar, o lugar atribuído ao homem, no que diz respeito às 
questões de violência contra a mulher, tem sido o de mantê-lo alienado da participação em uma discussão da qual é parte fundamental, se pretendemos pensar em transformações nos padrões de relacionamento entre homens e mulheres.

Em relação à produção sobre o tema, num vértice feminino, Gregori (2003) cita como valiosa fonte a pesquisa realizada por Heilborn e Sorj (1999), na qual é feito um balanço sobre os estudos de gênero desde 1975 no Brasil, identificando-se três principais linhas de enfoque: a primeira é voltada à Justiça e ao Judiciário, descrevendo as formas de compreensão e a forma de operação deste segmento em relação à questão da violência contra a mulher. A segunda linha "se dedica ao universo de representações femininas acerca da experiência da violência” (idem, p.12) e a última volta-se ao estudo das organizações e agências sociais que atuam diretamente no tratamento de mulheres vítimas de violência. Embora o tema desta dissertação esteja diretamente relacionado à mulher, uma vez que esta é um dos atores envolvidos na complexa questão da violência de gênero, não pretendemos, no escopo deste trabalho, nos aprofundar neste vértice. A justificativa para essa escolha fundamenta-se em dois pontos: primeiro, pela própria complexidade do tema que, acreditamos, mereça uma discussão que ultrapassaria o propósito deste trabalho. Em segundo lugar, a já vasta e competente produção nesta área tornaria nosso trabalho redundante. Portanto, optamos em apenas orientar o leitor para a consulta de alguns autores cuja produção seja considerada relevante no âmbito do tema em questão ${ }^{2}$. Nosso intuito neste trabalho é o de nos voltarmos para o estudo do universo masculino, mais especificamente representado pelo grupo de homens atendidos na Instituição já citada, no qual verificamos, ao longo dos anos de atendimento em grupos de reflexão masculinos, o

\footnotetext{
${ }^{2}$ Citaremos aqui os autores sugeridos por Gregori (2003), autora que também apresenta relevante trabalho na área (1993). Representando a primeira linha de pesquisa, destaca os trabalhos de Correa (1983), Ardaillon e Debert (1897), Brandão (1997), Carrara (1996), Soares (1996), Mussumeci Soares (1999), Vargas (1999). Na segunda linha de trabalhos por ela citados, destaca Grossi (1988, 1991, 1994), Fonseca (1984), Machado e Magalhães (1998) Pontes (1983). Na linha sobre as Ongs e agências sociais, cita: Pontes (1985), Gregori (1993), e Saffiotti e Almeida (1995) (p.12).
} 
predomínio do tipo de relação pautada pelos padrões hegemônicos de gênero. Desta forma, visamos poder contribuir com uma das facetas deste fenômeno ainda pouco estudadas, não somente do ponto de vista acadêmico, mas também aproximando a literatura de uma prática efetiva. Muitos estudos voltados ao universo masculino têm sido desenvolvidos (CONNEL, 1995; KAUFMAN, 1999; BIDDULPH, 2002, 2003; VALDÉS Y OLVARRÍA, 1997) principalmente focados nos aspectos da socialização dos homens e dos motivos que os levam a utilizar-se da violência nas relações não só com mulheres, mas também com outros homens. Estes trabalhos visam compreender como as expectativas e padrões sociais favorecem este tipo de desenvolvimento masculino e apontam para a possibilidade de novas formas de socialização masculina como meio de interferir na violência, tanto em sua manifestação na esfera pública quanto privada (doméstica, familiar). Encontramos, mais especificamente, em Connel (1995) o que denominou de diferentes masculinidades, evidenciando a impossibilidade de generalização ou homogeneização do universo masculino. Uma descrição mais pormenorizada da população masculina que focamos neste trabalho será feita em capítulo posterior, a fim de se evitarem tais generalizações.

A partir dos anos de experiência institucional e do desenvolvimento de uma metodologia que possibilitasse uma forma mais satisfatória de abordagem das questões familiares, ampliou-se o escopo da população atendida na PMFC, introduzindo-se, como elemento novo, a extensão do serviço à parte normalmente definida como agressora: os homens. Desta forma, a família como um todo pôde ser absorvido no programa, uma vez que trabalhamos conforme a perspectiva de que, num ambiente familiar onde predominam práticas violentas, todos os membros desta família estão sujeitos aos efeitos perniciosos desta dinâmica.

O presente trabalho faz um recorte, tomando como foco, sobretudo a experiência com o atendimento de homens e desenvolvendo subsídios teóricos concernentes à construção e à 
desconstrução da subjetividade nas diferentes masculinidades, assim como de suas expressões na violência em geral e na violência de gênero em especial.

Este estudo visa a enfocar o tema da violência praticada contra mulheres, assim entendida pelas políticas públicas, por dois vértices: o primeiro questiona a adoção de uma lógica não complexa e maniqueísta com a qual tais políticas habitualmente enfrentam essa questão, atribuindo valores positivos e negativos à complexa dinâmica das relações conjugais, de modo a polarizar a questão da violência em vítimas/agressores de forma rigidificada. Trabalhamos com a hipótese de que os efeitos destas políticas tendem a cristalizar e perpetuar aquilo mesmo que pretendem combater. A definição tradicional adotada, tanto juridicamente quanto no âmbito das políticas em geral, é o de violência doméstica. Esta definição tem sua utilidade para se identificarem e, por conseguinte, punirem culpados em casos onde a mulher é vítima de violências físicas por parte do seu companheiro íntimo. Contudo, de um lado, nem as punições têm qualquer efeito inibidor sobre aquele que comete agressões (normalmente eles são 'penalizados’ com o ineficaz pagamento de uma cesta básica e voltam para casa com suas companheiras humilhadas e desprotegidas), nem a violência física esgota o que se entende por práticas violentas entre homens e mulheres. Assim, este tipo de definição, a nosso ver, reduz muito a dimensão desta questão, reproduzindo o modelo maniqueísta de bom e mau, certo e errado, forte e fraco. Por este motivo, não adotaremos esta definição mais convencionalmente utilizada, mas bastante imprecisa, em nossas elaborações.

O segundo vértice pretende explicitar qual o lugar destinado ou "imposto simbolicamente” aos homens, procurando identificar quais os determinantes culturais, sociais e psicológicos organizadores da subjetividade masculina, visando a compreender como os papéis de gênero e as relações resultantes destes são distribuídas, transmitidas e perpetuadas pelos gêneros. Pretendemos realizar isto fazendo uso do referencial teórico de 
que dispomos, mas, em especial, procuraremos identificar as expressões da violência entre homens e mulheres, foco principal deste trabalho, por meio da análise do discurso dos participantes dos grupos, descrita no terceiro capítulo.

Ainda no terceiro capítulo, descreveremos a metodologia utilizada nesta dissertação, especificando a maneira pela qual os homens chegam à Instituição bem como descreveremos, por meio da reprodução de quatro sessões, o funcionamento dos referidos grupos de homens com os quais trabalhamos.

Embora não desejemos ignorar a inter-relação da violência praticada na esfera particular - nas relações de intimidade - com a violência mais ampla e socialmente visível, já que acreditamos que os modelos de relacionamento vividos na infância são grandemente determinantes na reprodução destes na vida adulta, nosso foco se voltará para as relações hierarquicamente desiguais entre homens e mulheres, objetivando verificar em que medida esta desigualdade dá sustentação ou justifica como naturais práticas agressivas e/ou violentas.

Para tanto, usaremos do arcabouço teórico psicanalítico a fim de cotejá-lo com estudos das relações de gênero desenvolvidos nas Ciências Sociais e na Antropologia, com o intuito de ampliar a compreensão da questão da transmissão e perpetuação das relações violentas.

No primeiro capítulo, intitulado Por que falar de homens?,é feito um histórico da Instituição onde a prática deste trabalho se dá. Faz-se também um apanhado da questão da violência praticada na família, ressaltando-se a importância do movimento feminista no processo que culminou com os estudos de gênero, e propondo, pela contextualização da prática institucional na qual este trabalho se baseia e por meio de bibliografias referentes ao tema da masculinidade e gênero, atualizar o debate acerca da violência de gênero, a fim de se proporem novas formas de se pensar neste assunto. 
O segundo capítulo, O campo construcionista e a violência de gênero, aborda os estudos de gênero através da ótica do construcionismo social, área das Ciências Sociais representada por autores como Carol Vance, Jeffrey Weeks, Gayle Rubin e outros, que questiona a naturalização de conceitos, práticas e identidades ligadas à sexualidade e ao gênero. O campo dos estudos de gênero aborda a questão da violência do vértice das construções sociais e das relações de poder contidas nas mesmas, como será discutido adiante neste trabalho. A abordagem construcionista representa o que há de mais contemporâneo nos estudos de gênero, tendo sido fortemente despertada com base no problema que representou o surgimento da Aids na década de 1980 e na necessidade de se estudar as práticas sexuais que, se acreditava, estavam diretamente relacionadas à disseminação do HIV.

O quarto capítulo, O universo masculino por distintas óticas, expõe a discussão de diversos autores voltados ao tema da masculinidade (Oliveira, Connel, Hurst, Valdés y Olavarria, Acosta e Barker). Propomos, ainda, a realização de uma discussão inteiramente fundamentada na metapsicologia psicanalítica, utilizando-nos das teorias descritas por Freud e seguidores, bem como das idéias de psicanalistas contemporâneos, como João Alberto Carvalho, Isabel Kahn Marin e Maria Rita Khel, discriminando as diferentes acepções de violência, pela ótica metapsicológica, na qual narcisismo, desamparo e idealização articulam-se como conceitos-base. Procuraremos compreender a violência de gênero e suas semelhanças e dessemelhanças com relação à noção de violência como entendida pelos autores citados. A discussão destes temas por um prisma psicanalítico busca contribuir com a ampliação da compreensão destes fenômenos, sem, contudo, restringir-se ao âmbito teórico. Os autores contemporâneos escolhidos o foram justamente pelo aspecto de aplicação prática na qual suas elaborações teóricas se fundamentam. Estes autores evidenciam, por sua 
obra, o interesse em ampliar o escopo de utilização da psicanálise para a esfera sociocultural, assim como haviam feito Freud, Winnicott e outros pensadores da cultura.

Finalmente, o trabalho encerra-se com uma discussão que procura articular os quatro capítulos e levantar hipóteses que sugiram novas formas de enfrentamento e, em especial, de prevenção das questões de violência na família e da violência permeada pelas questões de gênero, ditadas por uma cultura de masculinidade hegemônica.

À guisa de conclusão, usarei extratos de falas de um grupo focal (entrevista de followup) realizado ao final dos quatro encontros com alguns dos participantes.

A reflexão sobre o discurso destes tem o sentido não apenas de ampliar a compreensão dos códigos pelos quais estes homens são regidos (uma vez que considerados pela ótica da hegemonia masculina tradicional), mas também de nos fornecer subsídios para o questionamento de políticas de transformação social mais eficientes do que as adotadas de forma inoperante até os dias atuais. Verificamos, por meio da entrevista de follow-up realizada como parte de uma pesquisa que se deu concomitantemente aos atendimentos ${ }^{3}$-, com um grupo de homens, suas opiniões e sentimentos a respeito da experiência de serem atendidos nos referidos grupos.

\footnotetext{
${ }^{3}$ A referida pesquisa (2004) foi um trabalho conjunto entre a PMFC e a Unicamp, com financiamento da Fapesp (Fundo de Amparo à Pesquisa de São Paulo) e Prosare (Programa de Sexualidade e Saúde Reprodutiva) visando avaliar a metodologia da instituição com vistas a proposição de novas políticas públicas. A pesquisa foi coordenada pela Dra. Maria Coleta Oliveira, (Nepo- Núcleo de Estudos Populacionais/ Unicamp) e Malvina Muszkat (PMFC), e intitula-se Avaliação de um Método de Intervenção no Enfrentamento da Violência Intrafamiliar.
} 


\section{POR QUE FALAR DE HOMENS?}

Foi com base em uma perspectiva pautada pela ideologia do movimento feminista da década de 1970, pela qual se visava a intervir nas perniciosas práticas violentas impingidas à mulher, que se criou a Pró-Mulher, hoje re-batizada de Pró-Mulher, Família e Cidadania (PMFC).

A PMFC é uma Organização Não Governamental que conta com uma equipe multidisciplinar de psicólogos, advogados, assistentes sociais e presta serviço às famílias de baixa renda do município de São Paulo que se encontram em situação de violência e/ou conflitos familiares e/ou conjugais.

De início, voltada exclusivamente ao público feminino vítima de violência doméstica, que vinha encaminhado pelas Delegacias da Mulher, Varas da Infância e Juventude, e serviços judiciários públicos, hoje presta serviço à família como um todo, incluindo-se companheiros, filhos e outros familiares que se encontrem envolvidos no conflito doméstico-familiar.

Até 1993, nosso trabalho centrava-se no atendimento jurídico e psicológico das mulheres vítimas de violência e em situação de separação conjugal. O atendimento era totalmente gratuito, e acompanhávamos seus casos juridicamente, quando necessário, até a homologação dos processos. No entanto, verificávamos um alto índice de desistências ou interrupções no atendimento, ou, ainda, um número significativo de mulheres agredidas que se arrependiam das queixas contra seus companheiros e interrompiam o processo, ou, até mesmo, voltavam a coabitar com os homens de quem haviam legalmente se separado.

Verificávamos também, com base nos relatos e demandas das mulheres, a preocupante situação em que se encontravam seus filhos, testemunhas dos atos violentos 
praticados contra suas mães. Essas crianças ou jovens apresentavam distúrbios emocionais e de comportamento, baixo rendimento escolar e problemas de saúde. Cuidar exclusivamente das mães, portanto, embora por extensão pudesse repercutir na condição de seus filhos, não tratava de forma mais direta um problema de graves dimensões: as repercussões destas vivências familiares sobre a prole ${ }^{4}$.

Outro fator, fornecido pela psicanálise de casal e família e observado na nossa prática clínica, confirma como determinadas dinâmicas de relacionamento se repetem ainda que os parceiros sejam distintos. Ou seja, o padrão de relacionamento deve ser compreendido como uma forma de comunicação, já que a escolha de parceiros não é aleatória e, sim, calcada em estruturas inconscientes primitivas, bem como em modelos identificatórios com as famílias de origem de cada um dos sujeitos. Sem entender-se qual é a comunicação que está ocorrendo e qual a necessidade de se estabelecerem determinadas pautas de relacionamento, troca-se o parceiro, mas se perpetua o padrão quando da formação de uma nova dupla.

Considerando que o homem, como membro de uma família, é parte ativa e operante de um sistema vivo de interações afetivas, ao simplesmente retirá-lo, impedimos que a família possa refletir sobre seu funcionamento de maneira global e privamos seus membros da possibilidade de aquisição de recursos pessoais capazes de prover o desenvolvimento de relações mais gratificantes ou do ingresso num sistema ideológico alternativo.

Numa família onde há violência praticada contra a mulher, esta certamente não é a única vítima: todos os membros desta família sofrem as conseqüências desta dinâmica de relacionamento.

Tratar somente o pólo feminino reforça e perpetua a idéia de que a mulher é incapaz de cuidar de sua própria história e destino, aprisionando-a num lugar vitimizado e

\footnotetext{
${ }^{4}$ Dados levantados por RUDO, Z. E POWELL, D. Family Violence: A Review of the Literature. Florida, 1996, do Florida Mental Health Institute da University of South Florida, corroboram nossos dados relativos aos inúmeros efeitos danosos sofridos por filhos vivendo em famílias violentas. Um exemplo: Straus et al. (1980), numa pesquisa nacional nos EUA, verificam que filhos de famílias violentas apresentam índices de violência contra suas esposas, quando da constituição de suas famílias, 1000\% maior que os de famílias não violentas.
} 
aumentando as distâncias nas relações pautadas por um modelo hegemônico de relações de gênero. A comunicação entre o casal vai-se inviabilizando, uma vez que o homem é afastado e isolado como agressor.

Na violência doméstica, assim como entendida em sua acepção tradicional ${ }^{5}$, não há vencedores: a destruição paulatina do sentimento de amparo, amor e auto-estima é comum a todos os membros, incluindo-se aí o "agressor" identificado. Acreditamos que o homem, quando visto exclusivamente como agressor, sofre um processo de exclusão dentro da própria família e da sociedade, não lhe sendo facultada qualquer possibilidade de reparação, ou de inclusão num sistema ideológico alternativo. Posto de outra forma, a abordagem do fenômeno, ou das práticas violentas, feita por um prisma dualista, encerra os homens ora como sujeitos da agressão, ora como vítimas da exclusão, o que impede uma compreensão mais global de todos os aspectos envolvidos nesta questão, inviabilizando ações mais eficazes na transformação destes padrões. Há ainda que se ressaltar, como observa Kaufman (1994), que, na vivência de masculinidade hegemônica, há uma intrínseca associação entre poder social e privilégios, e dor, isolamento e carência de poder. Em suas palavras:

Pelo fato de ser homens, gozam de poder social e de muitos privilégios, mas a maneira como este mundo de poder foi armado causa dor, isolamento e alienação tanto às mulheres quanto aos homens. Isto não significa equiparar a dor dos homens com as formas sistemáticas de opressão sobre as mulheres, somente quer dizer que o poder dos homens no mundo tem um custo para todos nós (idem, p.63-4, grifo e tradução nossa).

A estruturação das relações entre homens e mulheres, abordada do ponto de vista de gênero, refere-se a uma concepção do masculino e feminino construídos na cultura. O

\footnotetext{
${ }^{5}$ Usamos aqui a denominação comumente utilizada para tratar da questão da violência praticada no âmbito doméstico, como sugere Saffiotti (nota 1, pág. 8), aquela que é praticada pelo homem contra sua companheira. Acreditamos, contudo, que esta definição, embora descreva um dos tipos de prática violenta, a física, seja muito restritiva e impeça uma compreensão mais abrangente, uma vez que trata da questão, atribuindo papéis fixos aos atores -vítimas e agressores. A desconstrução desta fixidez e estereotipia dos lugares atribuídos a homens e mulheres é um dos questionamentos centrais de nosso trabalho.
} 
modelo de masculinidade hegemônica-homofóbica ${ }^{6}$, predominante na população que atendemos na Pró-Mulher, não se restringe ao imaginário da população masculina, sendo parte constitutiva também da população feminina. Marcadamente idealizado, torna-se, por esta característica, impossível de ser atingido, exercendo, contudo, poder controlador sobre homens e mulheres.

Uma definição de masculinidade hegemônica citada por Kimmel (1994), baseada no sociólogo americano Erving Goffman, nos dá a dimensão não só do que se entende por diferentes masculinidades, já que sua definição, uma vez que inclui uma série de prescrições das quais os homens de nossa amostra estão excluídos, já os coloca, em relação àqueles, em outra masculinidade. Esta, como se vê a seguir é uma definição bastante restritiva quanto às possibilidades facultadas ao universo masculino daquilo que seria o desejável. São elas: ser jovem, casado, branco, urbano, heterossexual, de classe dominante, com nível universitário, de bom aspecto, peso e altura, com emprego de período integral e, ainda, um homem no poder, com poder e de poder. A masculinidade hegemônica prescreve também aspectos tais como: ser "forte, bem-sucedido, capaz, confiável e aparentar autocontrole. As próprias definições de virilidade que desenvolvemos em nossa cultura, diz Kimmel, perpetuam o poder que uns homens têm sobre outros e que os homens têm sobre as mulheres” (idem, p.50-51). Evidencia-se, aqui, a impossibilidade de se caracterizarem todos os homens de forma genérica, sem se considerarem as inúmeras variáveis e suas distintas inserções sociais, culturais, raciais, étnicas, de escolaridade, de preferência sexual, o que implica uma vasta

\footnotetext{
${ }^{6} \mathrm{O}$ padrão de masculinidade denominada hegemônica baseia-se fundamentalmente no modelo patriarcal. Tem como valores: o poder do homem sobre a mulher e crianças e a complementar submissão da mulher a ele, atribuindo lugares de superioridade e inferioridade a uns e outros. Associa virilidade e masculinidade à força física, prontidão sexual, coragem. Este homem é ainda provedor e emocionalmente forte, uma vez que fragilidade é algo associado ao universo feminino. Sendo assim, é necessário afastar-se de qualquer atributo vinculado ao mundo das mulheres, o que os leva a um comportamento homofóbico. O risco de uma aproximação de cunho mais afetivo com um outro homem pode levá-lo a ser mal-interpretado como alguém com pendores homossexuais. Ele é regido por rígidos padrões quanto ao comportamento sexual, em que é imposta uma atividade intensa do homem e um recato e timidez da mulher. Ao homem está reservada a esfera do mundo da rua, do público, e à mulher, o mundo da casa, doméstico, privado. Desta forma, exige-se que o homem tenha emprego (implicando, assim, entradas financeiras suficientes para o provimento da família) e que a mulher cuide da casa, dos filhos, do marido.
} 
gama de composições hierárquicas e de opressão de determinados grupos masculinos sobre outros. O desejável, acima mencionado, está intimamente relacionado à idealização, à supervalorização e a um caráter ilusório (CARVALHO, 2003), portanto, irreal e inatingível. Como descreve Freud em seu artigo Sobre o Narcisismo: uma introdução (1914) e, posteriormente, em 1921, em Psicologia de Grupo e Análise do Ego, a idealização é um mecanismo que empobrece o sujeito, implicando perda de partes do ego do indivíduo, com base em um mecanismo pelo qual a libido do próprio ego é transferida para o objeto valorizado, podendo este ser os valores hegemônicos disseminados na cultura. Trataremos com mais detalhes destes mecanismos no capítulo 4, onde, a partir do vértice metapsicológico freudiano, procuraremos levantar hipóteses que nos auxiliem na compreensão de como se dá e por que se perpetua a adesão dos sujeitos a rígidos padrões presentes na cultura.

Do ponto de vista da biologia, define-se masculino e feminino com base na constituição biológica dos seres, sendo o aparelho reprodutivo o que demarca o que é próprio a cada sexo. Esta visão, que irá configurar aquilo que é do universo feminino e do masculino, firmada nas diferenças anatômicas, será, como veremos no capítulo 2, não só refutada, como combatida, pelos estudiosos do construtivismo social, desassociando-se a biologia da cultura. Com efeito, a constituição sexual de cada indivíduo está longe de esgotar a questão da identidade de gênero. No campo de estudos sobre o masculino, a construção das várias masculinidades ${ }^{7}$ ocorre de maneira complexa e está vinculada tanto a modelos da cultura quanto à estruturação inconsciente daqueles responsáveis pela criação dos seres humanos: pais e mães, estes também produtos da cultura. Vemos assim que uma mãe, por

\footnotetext{
7 A concepção sobre as diversas masculinidades foi desenvolvida inicialmente por Connel (1995) e será explicada de forma mais detalhada no capítulo 4.
} 
exemplo, ao prover os cuidados básicos ao seu bebê-menino, o fará de maneira diferente de como atuará com seu bebê-menina. (KERNBERG, 1995).

Neste sentido, vemos desde logo que não se pode tratar a questão do masculino dissociada daquela do feminino, pois é a partir dos primeiros contatos com as figuras tanto materna quanto paterna que irá sendo construída a noção relativa a cada gênero. Sendo tanto produtores quanto produtos da mesma cultura, não se pode tratar esta questão isolando uma das partes ${ }^{8}$.

Ainda calcados na constituição biológica do homem, fatores como a existência do pênis como órgão sexual, massa e força física superiores às das mulheres deram caráter de “naturalidade” à associação entre masculinidade e agressividade, como também à prontidão e potência sexual, levando os homens, há muitas gerações, a adentrarem o chamado “mundo dos homens” por vias geralmente bastante dolorosas, verdadeiros rituais de iniciação (MILES,1991).

A homofobia nega, com freqüência, o aspecto emocional do homem (GIFFIN, 1994). Não há nisto qualquer tentativa de justificar comportamentos violentos praticados por homens, como tampouco de sobrecarregar as mulheres como responsáveis por relações de violência na qual estejam envolvidas. Há isto sim, a constatação da existência de uma situação muito mais complexa e dinâmica em que se encontram tanto homens como mulheres.

A violência é uma forma possível, embora deletéria, de resposta, que tem a finalidade de procurar solucionar um conflito por meio da eliminação de uma de suas partes. Obviamente que nesta idéia está implícita a noção de força, pois o mais forte impõe sua vontade ao mais fraco. Contudo, valendo-se de uma visão das dinâmicas familiares, sabemos

\footnotetext{
${ }^{8}$ Apenas a título de viabilizar este estudo, voltamo-nos mais exclusivamente ao masculino. No entanto, estamos cientes de que, embora haja características específicas neste universo masculino que estamos estudando, não se pode, para efeito de políticas mais amplas e efetivas, tratar o masculino dissociado do feminino.
} 
que a utilização da violência pode ser uma forma bilateral em que comumente se verifica uma complementaridade - ainda que se manifeste de maneiras distintas - na pauta de relacionamento.

Nesta perspectiva, faz-se fundamental a análise das questões de gênero, pois, se à mulher é atribuído o papel de vítima, que lugar fica reservado ao homem? Que opções lhe restam quando não lhe é dada a possibilidade de inclusão, de amparo, de escuta? O rígido modelo cultural masculino, compartilhado tanto por homens quanto por mulheres, se por um lado transmite uma herança de poder, por outro exige um desempenho quase impossível de se atingir, gerando sentimentos de angústia, depressão e impotência.

Passamos, portanto, a referir este tipo de violência não mais como violência doméstica, mas como violência INTRAFAMILIAR, e encontramos, ainda, na metodologia de trabalho proposta pela mediação familiar, um instrumento que viabilizou que passássemos a abordar de maneira mais integradora o fenômeno das relações violentas na família.

A fim de contextualizar o trabalho realizado na Instituição, daremos uma breve explicação sobre os princípios da mediação. Contudo, não nos estenderemos numa discussão mais ampla sobre esta metodologia, uma vez que isto se encontra fora do escopo desta dissertação ${ }^{9}$.

A mediação é um método alternativo de resolução ou pacificação de conflitos, calcado em uma ampla gama de teorias do conhecimento: teorias da comunicação, teoria sistêmica, teoria psicanalítica, princípios do direito e teorias construtivistas. Ela funciona

\footnotetext{
${ }^{9}$ Sugerimos três trabalhos para uma compreensão mais abrangente do tema, sendo um deles o resultado de 10 anos do uso desta metodologia na instituição aqui referida: MUSZKAT, M. (org.) Mediação de Conflitos: pacificando e prevenindo a violência. São Paulo: ed. Summus, 2003; MUSZKAT, M. Guia prático de mediação de conflitos em famílias e organizações, São Paulo: ed. Summus, 2005; SUARÉS, M. Mediación: Conducción de disputas, comunicación e técnicas. Buenos Aires: ed. Paidós, 1996.
} 
pelo princípio da não-adversariedade, ou seja, enquanto as formas jurídicas tradicionais de disputa que conhecemos estão baseadas numa lógica do ganhador/perdedor, a mediação baseia-se em princípios de negociação e busca, partindo da autodeterminação das partes para encontrar soluções mutuamente satisfatórias. É uma metodologia que desperta os indivíduos como agentes responsáveis por suas próprias decisões e ações, bem como pelas conseqüências destes. Desta forma, atua na contramão da lógica paternalista, pela qual um terceiro - um juiz - arbitra sobre a forma de se encaminharem questões dos sujeitos envolvidos numa disputa familiar.

A mediação busca flexibilizar posturas, fazendo com que se possa pensar a situação de conflito de outros pontos de vista. Assim, poder despertar no sujeito a possibilidade de colocar-se no lugar do outro, torna-se um dos pontos fundamentais na facilitação das relações cotidianas interpessoais. A mediação busca a desconstrução de paradigmas culturais ou pessoais, a fim de que se refaçam e ampliem as narrativas pessoais. Como conto minha história? Como me vejo no mundo? Que lugar ocupo nas minhas relações interpessoais e familiares? Em que lugar me situo em relação ao outro? Todas estas indagações e as respostas a elas são habitualmente pensadas como versões únicas e verdadeiras. "O trabalho fundamental do mediador é construir uma história alternativa, que permita ver 'o problema' por todas as partes, a partir de outros ângulos.” (SUARÉS, 1996, p.62).

Ao longo dos anos de experiência da PMFC, desenvolveu-se uma metodologia que, se por um lado atende e é pautada pelos princípios fundamentais da mediação (tais como a garantia de equidade entre as partes, a postura imparcial do mediador, o desenvolvimento do protagonismo e da noção de responsabilidade sobre as próprias ações, a busca por uma mudança de mentalidades que amplie horizontes e flexibilize posturas para incluir-se a percepção de um outro cujos desejos e necessidades mereçam reconhecimento), por outro, ela acabou por incorporar novas formas de abordagem a fim de se atenderem às 
especificidades da população-alvo. Deste modo, adaptou-se a metodologia e implantaram-se os grupos inicialmente denominados de Grupos de Pré-Mediação masculinos e femininos que são aqueles a partir dos quais desenvolvemos este trabalho.

Além do tratamento dado aos sujeitos que procuram a Instituição em busca de auxílio no âmbito de seus conflitos familiares, busca-se também, por meio da intermediação da Instituição com outros dispositivos sociais, inserir o sujeito na rede social mais ampla, para garantir-lhe sua condição de cidadania com base nos princípios postulados pelos Direitos Humanos, tornando-o responsável como ator de suas ações, a fim de transformar sua história. Desta forma, cunhamos a designação mediação institucional, fazendo referência a esta ampliação da metodologia.

A inclusão dos homens no atendimento da Instituição teve seu início em 1993. De acordo com o World report on violence and health, publicado pela Organização Mundial de Saúde em 2003, a questão da violência foi alçada como assunto de agenda internacional quando do encontro do World Health Assembly em 1996, em Genebra, no qual se adotou uma resolução declarando a violência um problema de saúde pública mundial de especial relevância, tendo em vista que esta foi responsável por mais de 1,6 milhões de mortes em todo o mundo, no ano de 2002. É também uma das principais causa mortis de pessoas entre 14 e 44 anos, sendo que por volta de 14\% das mortes se dá entre homens, ao passo que as mulheres representam 7\% desta estatística. É fato comprovado estatisticamente que os homens são os principais agentes de atos violentos, assim como as principais vítimas destes, tendo em vista que a violência é responsável pelos altos índices de mortalidade entre homens jovens (ROTHMAN, BUTCHART \& CERDA, 2003; WHO, 2002; CONNEL, 1995; CORSI, DOHMEN \& SOTÉS, 1995). Sem dúvida, os dados acima atestam a pertinência da inclusão dos homens nos trabalhos de violência de gênero. 
Segundo Hurst (2003), a corrente ideológica predominante no primeiro mundo no âmbito da violência doméstica foi dominada por uma abordagem cultural de estilo norteamericano, cujo vértice era o de tratar os homens como sendo “do mal” e, conseqüentemente, imprimindo temor ao "outro”. Essa visão estereotipada influenciou não apenas programas de combate à violência como também o tipo de justiça criminal praticada em diversos países, que 'importaram’ a metodologia americana e sua forma de abordagem, sem que estas pudessem ser adequadamente adaptadas às condições destas outras culturas, levando ao fracasso dos programas em muitos locais. É, portanto, importante discriminar entre programas voltados aos 'homens batedores' - ou de comportamentos violentos -, que visam eliminar um comportamento indesejado - nesse sistema o homem é tratado como alguém “do mal”, em um sistema normatizador de valores morais -, ou elaborarem-se programas em que se proponha parceria aos homens, considerando-os como parte interessada numa convivência mais prazerosa e gratificante. Programas cuja ideologia tenha como base um princípio maniqueísta bom/mau, em que o mau deve ser eliminado, disseminam sentimentos de hostilidade e persecutoriedade, criando barreiras ainda mais intransponíveis nos relacionamentos, em razão do lugar que designa os “do mal”10.

Entendemos como duas as principais razões que determinam a escassez de programas de inclusão masculina no Brasil: a primeira diz respeito ao fato de os atos violentos serem com freqüência associados a questões de cunho legal ou criminal, sendo habitualmente entendidos como circunstâncias a serem tratadas no âmbito da lei e ordem social. O foco predominante é o do combate, erradicação, eliminação de um comportamento indesejado, identificado normalmente com o parceiro masculino. Desta forma, atos violentos costumam ser combatidos pelo sistema penal e órgãos policiais e, não, prevenidos. Embora isso venha

\footnotetext{
${ }^{10}$ Em 2003 foi publicado pela World Health Organization relatório baseado numa extensa pesquisa realizada por Emily Rothman, na qual são listados todos os programas de intervenção voltados às relações íntimas violentas encontrados pela pesquisadora fora do circuito EUA e Canadá. O programa da PMFC encontra-se nesta lista.
} 
mudando em todo o mundo, também no que diz respeito à saúde pública, ainda cabe aos profissionais de saúde, como foco principal, o tratamento exclusivo das conseqüências destes atos $(\mathrm{WHO}, 2002)^{11}$.

Em relação à violência de gênero, associada às práticas sexuais e reprodutivas, pesquisadores (BARBOSA, 2003; PITANGUY, 2003) do âmbito das ciências sociais verificam que esta se evidencia nas práticas de sexo inseguro a que mulheres se submetem, uma vez que, em virtude das relações de poder desiguais presentes nas relações tradicionais de gênero, elas se encontram impedidas de negociar com seus parceiros formas seguras de prevenção das DST/AIDS. Conseqüentemente, pesquisas atuais indicam que mulheres heterossexuais com parceiros estáveis têm representado o grupo de maior vulnerabilidade nas estatísticas de contaminação pelas DSTs (CARVALHO, 2003; BARBOSA, 2003; PITANGUY,2003) ${ }^{12}$.

O segundo motivo pode ser pensado como subproduto do movimento feminista, que passou a ter forte impacto social a partir da década de 1970.

O movimento feminista foi responsável por ter revelado e explicitado a situação de extrema desigualdade e violência imposta a milhões de mulheres em todo o mundo, propiciando assim todas as mudanças e avanços que vemos hoje no campo dos direitos da mulher, em todos os âmbitos dos espaços privados e públicos. Embora sejam inegáveis os inúmeros avanços e conquistas das mulheres no que diz respeito aos seus direitos e à maior igualdade de condições, principalmente na esfera pública, as relações entre homens e

\footnotetext{
${ }^{11}$ Recente ato do atual presidente Luis Inácio Lula da Silva, de 25/11/03, cria lei que obriga profissionais de saúde de organizações tanto governamentais quanto não governamentais a denunciarem qualquer ocorrência em que se verifique que tenha sido praticada violência contra a mulher.

${ }^{12}$ Regina Barbosa (2003, p.339-389) discute criticamente este dado, apontando para a necessidade de haver políticas de transformação de mentalidades e paradigmas culturais que visem à prevenção e não, somente, ao combate de comportamentos. Barbosa reafirma a necessidade de se introduzirem as dimensões culturais, sociais e políticas nas categorias usadas na epidemiologia, em oposição às tradicionais abordagens comportamentalistas, e propõe o fortalecimento de estratégias de alcance social, estimulando-se movimentos sociais organizados.
} 
mulheres, pautadas por um imaginário tradicional de gênero, ainda as impedem de estabelecerem relações mais igualitárias com seus companheiros, como também atesta Carvalho (2003) ao evidenciar como ideais românticos presentes no imaginário cultural feminino são, também, fatores relevantes na impossibilidade de muitas mulheres negociarem relações sexuais protegidas com seus companheiros, resultando, dessa forma, no alto índice de contaminação por HIV, já mencionado.

A concepção de imaginário que aqui utilizamos, bastante apoiada naquela descrita por Carvalho (2003), está intimamente vinculada ao registro do narcisismo infantil, bem como das noções relativas a ego ideal e ideal do ego da teoria freudiana. Embora o próprio Freud não tenha feito a distinção entre estes dois termos (LAPLANCHE \& PONTALIS, 1983), outros autores, tais como Lacan e Lagache, distinguem o ego ideal do ideal do ego, associando o primeiro a um "ideal narcísico de onipotência forjado a partir do modelo de narcisismo infantil” (idem, p.190). Para Lacan, segundo Laplanche e Pontalis (idem, p.190), o ego ideal tem sua origem na fase por ele descrita como fase do espelho e pertence ao registro do imaginário. É habitualmente definido como um momento mítico, de plenitude narcísica, vivido na relação fusional entre o bebê e sua mãe. Nas palavras de Carvalho (2003, p.65), “o ego ideal corresponde à imagem idealizada do ego feita a partir do discurso apaixonado dos pais, havendo uma ausência de crítica e de objeção”. A impossibilidade de manter-se no registro narcísico do ego ideal levaria o ego, já mais desenvolvido, a procurar recuperar este estado de perfeição pela busca por atingir o ideal do ego que, dada a sua possibilidade simbólica, pode então se associar aos valores da cultura que contenham 'a promessa’ de recuperação do ego ideal perdido na infância.

A distinção entre o ego ideal e o ideal do ego ocorre, portanto, como descrito por Lacan, com o primeiro fazendo parte do registro do imaginário e o segundo, do registro do 
simbólico. Segundo Maria Rita Kehl ${ }^{13}$, o imaginário não admite pensamento uma vez que se encontra colado às imagens cujo significado é dado de forma fixa. Assim, o imaginário, segundo ela, impõe uma realidade de forma que o sujeito ficaria impedido de ser agente de si mesmo uma vez que suas ações e modos de ser já estariam definidos através de imagens saturadas de sentido (grifo nosso). O mundo, encerrado em seu caráter imaginário, não cria espaço para simbolizações e transformações. É esta, a concepção de imaginário, de forma bastante resumida, na qual nos baseamos ao falar de imaginário masculino. Contudo, este é, um conceito bastante abrangente, que envolve algumas das concepções básicas sobre as quais se sustenta a teoria psicanalítica, tais como narcisismo, superego, complexo de Édipo. Deste modo, ainda que retornemos à discussão psicanalítica no capítulo 4, sugerimos a leitura do capítulo 2, intitulado $O$ sonho, do livro de João Alberto Carvalho, O amor que rouba os sonhos, que vimos citando, no qual o autor faz uma detalhada e rica elaboração deste conceito.

Os estudos de gênero, que, juntamente com a teoria psicanalítica, usaremos como um dos pilares principais de compreensão do fenômeno das práticas violentas, decorrem diretamente dos movimentos feministas, sendo a expressão gênero tomada de início como sinônimo de estudos feitos por mulheres, sobre as mulheres e suas lutas em direção à igualdade e aos direitos plenos (BARBIERI, 1990; GREGORI, 1993).

O movimento feminista, contudo, tampouco pode ser pensado como um movimento homogêneo, de definição unificada, como assevera a antropóloga Maria Filomena Gregori (1993), uma vez que encerra tendências e práticas diversificadas. Ainda assim, seu impulso como movimento expressava, de maneira geral, "uma preocupação de eliminar as discriminações sociais, econômicas, políticas e culturais de que a mulher é vítima” (idem,

\footnotetext{
${ }^{13}$ Informação conferida por Kehl em comunicação oral na livraria Pulsional, em São Paulo, em 30/03/05.
} 
p.15). Desta forma explicitava, desde seus primórdios, uma relação desigual entre os sexos, na qual à mulher era atribuído um lugar de inferioridade construído social e culturalmente.

A crítica da autora recai na constatação de que o que se exigia das mulheres como decorrência do movimento, ou seja, o combate e a denúncia dos homens, não só excluía os homens deste processo de conscientização como também exigia uma postura de afastamento das mulheres, negando que estes mesmos homens fossem também seus companheiros.

Gregori ainda nos alerta: "O movimento feminista separa as mulheres dos homens, não tanto no sentido de afirmar que cada homem é responsável pela opressão, mas na medida em que todo o trabalho de conscientização é travado apenas por mulheres” (idem, p. 53). E continua "cabe aos homens - vistos como coletividade - serem cobrados e denunciados em suas manifestações autoritárias e/ou violentas. A eles não é dada a alternativa da conversão” (idem, ibidem). Vê-se, assim, que o tratamento dado às questões relativas aos problemas de gênero abordou o tema da violência contra a mulher, desde seu início, de maneira dualista, priorizando ações de proteção à mulher, sem, contudo, debruçar-se sobre a dialética contida nas relações interpessoais e conjugais.

Nessa ocasião, já se alertava para o cuidado necessário ao se tomarem as narrativas das mulheres como verdades absolutas, embora isso tenha sido importante para se entender sua visão e suas crenças quanto ao lugar que ocupavam nos relacionamentos e no mundo. Contudo, considerando-se que os relacionamentos são dinâmicas que se retro-alimentam ou complementam, é preciso também ouvir a versão masculina, "não tomando o masculino como dado, mas também como uma identidade que se constitui na trajetória, na vivência” (p.200), se o que se pretende é tratar das questões de relações de gênero.

Encontramos argumento semelhante em trabalho realizado por Arilha, Unbehaum e Medrado (Org.), em Homens e Masculinidade (1998). Dizem as autoras que, desde 1994, vem ganhando força a noção de que "indicadores de saúde das mulheres só se modificariam 
efetivamente na medida em que a população masculina, jovem e adulta, também mostrasse movimentos de mudanças em seus padrões de comportamento” (idem, p.16).

Lourdes Bandeira e Mireya Suárez (2002), em A polinização da violência contra a mulher e o fortalecimento da cidadania, localizam o início do tratamento das questões de violência de gênero no Brasil e citam artigo realizado por Elaine Reis Brandão, baseado em sua dissertação de mestrado, no qual analisa depoimentos de mulheres que recorrem às Delegacias Especiais da Mulher a fim de denunciar violência sofrida no âmbito doméstico. A autora tem como ponto central "explicar os motivos que levam as mulheres a solicitar a suspensão da queixa, concluindo que várias lógicas interferem entre vítima e acusado... gerando pressões que desencorajam a maioria das mulheres a sustentarem as acusações” (idem, p.301). A autora refere também a necessidade de se considerar que as relações de violência se perpetuam porque trazem em si idéias firmemente arraigadas na cultura sobre o que são imagens e papéis tradicionalmente atribuídos a homens e mulheres.

O alto índice de desistência ou de arrependimento de mulheres em relação às queixas feitas contra seus companheiros tampouco é um dado desconhecido de várias outras instituições que se voltaram ao atendimento de mulheres vítimas de violência, como a Casa Eliane de Grammont, as Delegacias Especiais da Mulher e o SOS-Mulher de São Paulo, o qual foi descrito no trabalho de Gregori. Encontramos referências a este tema também em Bandeira e Suárez (2002). Numa linha semelhante à desenvolvida por Gregori e outros (SARTI, C., 1996; MUSZKAT \& MUSZKAT, 2003) entendemos como necessário identificar a demanda feita por estas mulheres que não se satisfaz ao simplesmente punir-se ou afastar-se seu companheiro.

É interessante ressaltar que, embora tenha havido produção de trabalhos relativos ao mundo masculino e à masculinidade, como resposta ao movimento feminista e à conseqüente homogeneização atribuída aos homens sob a denominação de Masculinidade 
(CONNEL, 1995), ainda assim estes estudos ficaram relegados a segundo plano, dada a força com que foram enfocados os trabalhos voltados à mulher (ARILHA, RIDENTI \& MEDRADO, 1998).

Os resultados obtidos nos últimos 30 anos na tentativa de diminuir a violência intrafamiliar têm sido pouco significativos. De maneira geral, contudo, há uma mobilização que começa a dar-se em nível global, pela qual a questão da violência doméstica e/ou familiar vem sendo enfocada como algo a ser tratado em parceria com os homens.

Em nível global, a questão de se trabalhar com homens em parceria a fim de prevenir e superar a violência doméstica tem surgido como um novo e fundamental desenvolvimento no campo da violência doméstica, fundamentado por organizações tais como a UNICEF. Este é exatamente o caso na América do Sul, Ásia e África (HURST, 2003. Tradução nossa).

Como exemplo, cito o movimento internacional denominado Campanha do Laço Branco, cujo objetivo é sensibilizar homens pelos próprios homens, na luta contra a violência praticada contra as mulheres ${ }^{14}$.

Mais recentemente, em pesquisa realizada por Acosta \& Barker (2003), no Rio de Janeiro, das organizações Noos e Promundo, também associados à Campanha do Laço Branco no Brasil, encontramos subsídios que reforçam nossa convicção de incluir os homens nas ações e projetos de prevenção à violência intrafamiliar, bem como confirmam nossa hipótese quanto à maior prevalência de atos violentos nas camadas menos educadas da população masculina. Esta pesquisa, como também os trabalhos de Robert Connel (1995), evidencia a importância da reformulação das concepções sobre masculinidade e violência, enfatizando a necessidade de inserção da população masculina num projeto mais amplo,

\footnotetext{
${ }^{14}$ Para informações sobre este movimento no Brasil e no mundo, acesse o site: Campanha do Laço Branco. Disponível em: <www.lacobranco.org.br>. Acessado em: 2003.
} 
discriminando-se diferentes masculinidades e, assim, reafirmando-se a necessidade de considerar-se o universo masculino com base nas suas especificidades e não como um universo regido de forma homogênea, como ele tem sido abordado quando se pensam políticas de enfrentamento da violência praticada por homens.

Encontramos em Oliveira (2002), no capítulo intitulado Persistências e o fator de inserção social, de sua tese de doutorado, discussão que corrobora a necessidade de discriminarem-se diferentes masculinidades, ao questionar-se uma crise da masculinidade, ou seja, uma crise generalizada vivenciada pelos homens em relação a terem de exercer o poder, ou se esta crise se refere a determinados extratos sociais masculinos. O autor sugere que este descontentamento concentra-se nos segmentos socioeconômicos médios e altos,

mais sujeitos às mudanças da voga pós-moderna, pois se observa que o padrão consagrado de conduta masculina ainda é bastante valorizado entre boa parte dos homens pertencentes aos segmentos populares, menos afetados pelas inúmeras possibilidades que o mercado oferece aos homens de outros segmentos sociais melhor favorecidos (idem, p.234).

Nas camadas populares, os valores masculinos hegemônicos são mantidos como algo que confere aos homens vantagens outorgadas por sua condição de gênero, ao mesmo tempo em que sua condição de dominação em outras esferas sociais mais amplas são esparsas. Desta forma, Oliveira e outros (MUSZKAT \& MUSZKAT, 2003) verificam que a valorização do masculino lhes agrega valor simbólico importante, uma vez que, quanto menos liberdade e capital simbólico tiverem no âmbito social, maior será o apego a este outro capital, conferindo-lhes ganhos específicos que a eles são recusados nas esferas acima referidas.

Retomando a citada pesquisa carioca de 2003, esta caracterizou-se num estudo quantitativo e qualitativo sobre a violência de gênero e saúde sexual reprodutiva em homens entre 15 e 60 anos, advindos de dois bairros distintos do Rio de Janeiro. O estudo foi realizado com três grupos: dois advindos de comunidades de baixa renda e um grupo de classe 
média, tendo sido entrevistados e avaliados 749 homens. O estudo verifica que, destes, um total de 51,4\% afirmam já ter usado algum tipo de violência contra suas parceiras íntimas, seja física, seja psicológica ou sexual.

A pesquisa ainda associa o uso da violência contra mulheres a dois fatores: o nível de escolaridade e o processo de socialização dos homens, com maior índice de práticas violentas naqueles que foram vítimas ou testemunhas de violência contra a mulher em suas famílias de origem. É importante ressaltar que os pesquisadores atribuem maior relevância ao nível de escolaridade do que à renda como determinante de práticas violentas.

Estudos realizados no Brasil (ACOSTA \& BARKER, 2002; PAIVA, 2000; OLIVEIRA, M.C, MUSZKAT, M et. al, 2004 ; CORSI, DOHMEN \& SOTÉS, 1995; e outros), sugerem que os "papéis sexuais" ou os chamados "scripts de gênero"15, com os quais os homens são socializados em nossa cultura, reforçam a noção de que práticas violentas de gênero estão ‘autorizadas’ ou são ‘justificadas’ na medida em que as mulheres apresentem comportamentos que sejam interpretados como estando em desacordo com a manutenção do lugar do homem em um sistema hegemônico tradicional.

Em pesquisa conjunta realizada pela PMFC e Unicamp, financiada pela Fundação de Amparo à pesquisa de São Paulo/FAPESP e Programa de Sexualidade e Saúde Reprodutiva/PROSARE verificou-se que o rompimento de acordos na divisão sexual do trabalho dentro do esquema tradicional de gênero desperta, tanto em homens quanto em mulheres, um sentimento de traição, de ter sido lesado pelo outro. É interessante notar que, para muitas mulheres de nossa mostra, comportamentos como: casos extraconjugais, ocorrências de práticas violentas e falta de interesse nas questões domésticas eram plenamente tolerados, enquanto se mantinha o acordo dos papéis sexuais. No caso de rompimento destes, (quando o homem, por exemplo, se recusa ao papel de provedor, gastando seu dinheiro fora

\footnotetext{
${ }^{15}$ No capítulo 2, sobre construtivismo social, faremos um maior detalhamento destes conceitos.
} 
de casa), o sentimento de traição e desejo de retaliação se materializa nos inúmeros pedidos de separação e pensão alimentícia que recebemos todos os meses em nosso serviço (Pesquisa PróMulher/Unicamp, 2004).

Novamente, na referida pesquisa NOOS/ Promundo, é interessante observar que os motivos alegados pelos homens pesquisados para justificar práticas violentas são semelhantes àqueles que encontramos no grupo de atendimento a homens na PMFC. São eles: ciúme, infidelidade, assuntos domésticos - que vão desde a criação dos filhos e problemas financeiros até queixas quanto aos cuidados dispensados à casa e aos filhos pela mulher, ou, ainda, serem importunados pelas mulheres (Acosta, F; Barker,G, 2003, p.6). É comum que, nos grupos que coordenamos, sejam verbalizadas queixas como: "ela deixa tudo uma bagunça... ta sempre na casa da mãe e não cuida das obrigações dela dentro de casa”, ou ainda, “mãe que é mãe tem que pensar no filho em primeiro lugar, cuida direito, ama o filho e depois pode pensar no prazer” (sic).

Aqui, é possível constatar a rigidez com que os papéis sexuais são significados, determinando a atribuição de funções estáticas. Inexiste, com freqüência, a possibilidade de dotação de sentidos distinta das preconizadas tradicionalmente, impedindo, por exemplo, que seja identificada uma depressão numa jovem mãe, que a impeça de cuidar adequadamente de seu bebê.

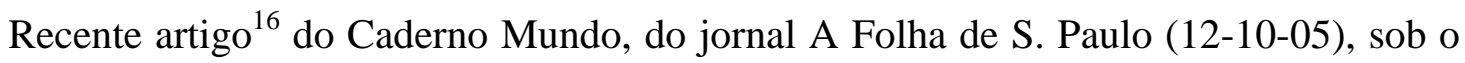
título: Igualdade sexual combate pobreza, diz ONU, cita relatório do Fundo de População das Nações Unidas em que este "impõe como condição para exterminar a pobreza no mundo a igualdade entre homens e mulheres” (idem, p. A-10). Continuando, lemos: “O tema de 2005 o relatório é anual - é a igualdade de gênero e saúde reprodutiva. Segundo o fundo, não será possível combater a pobreza enquanto mulheres sofrerem discriminações, violência e abuso

\footnotetext{
${ }^{16}$ Flor, A. Igualdade sexual combate pobreza, diz ONU. Folha de São Paulo. São Paulo. 12 de Out. 2005. Caderno Mundo, p. A-10.
} 
sexual e não tiverem os mesmos direitos políticos, sociais e econômicos dos homens” (idem, ibidem). O relatório fornece dados alarmantes, tais como: a metade dos 40 milhões de infectados por HIV no mundo são mulheres, sendo a principal causa de mortalidade em mulheres em idade reprodutiva e 1 em cada 3 mulheres em todo o mundo foi espancada, ou sofreu algum tipo de coação sexual. Sugere que a educação das meninas é um ponto fundamental, contribuindo com o adiamento do casamento e de gravidezes prematuras.

Vemos aqui comprovada a relevância do tema não só em nível mundial como especialmente em nível nacional, onde a pobreza e a desigualdade social são fatos observados em nosso cotidiano. No entanto, chama-nos a atenção o foco direcionado apenas ao feminino, desconsiderando-se a dialética presente na desigualdade de gênero, e a necessidade de se proporem políticas voltadas aos homens. Verificamos um mosaico bastante abrangente, tanto da literatura quanto dos autores dos estudos de gênero, no qual a discussão se volta à questão feminina. Desta forma, entendemos como plenamente justificada a propriedade em abordarmos a questão da desigualdade e violência de gênero, voltando-nos ao vértice masculino.

Assim, o intuito do trabalho com os homens é o de poder aumentar a rede de significações, seja de suas vivências, seja de suas crenças quase obrigatórias sobre o que é ser homem e o que é ser mulher, e que, em razão de suas condições de socialização, se mostram empobrecidas, restando-lhes poucas opções de significados que lhes garantam a identidade desejada.

Citando João Carvalho (2003, p.26),

Distintamente de uma antropologia que considerava o mundo humano como natural, consideramos agora a construção social, o relativismo das produções sociais. Partimos do pressuposto de que a relação entre indivíduo e sociedade é uma inter-relação, homem e cultura são indissociáveis. O homem não é passivo diante da cultura, mas elemento constituinte de si próprio e da sua cultura... Estamos atentos à dialética de mudanças e 
permanências, considerando ambas as dimensões como presentes e se constituindo mutuamente.

Embora ele, aqui, se refira ao homem ao falar do indivíduo e da cultura, acreditamos ser este apenas mais um modo 'naturalizado' de referir-se ao ser humano no masculino. Contudo, a idéia relevante é a de que há uma co-autoria, uma inter-relação na construção dos códigos sociais, compartilhada pelos indivíduos de determinado agrupamento sociocultural, que é transmitida não só de forma consciente, como, notadamente, de forma inconsciente, uma vez que é revestida de seu aspecto 'natural'.

Esta é uma perspectiva que pretendemos destacar na discussão deste estudo, propondo que, em vista do que até agora foi discutido pelos diferentes autores apresentados, bem como de nossos próprios achados no trabalho com homens, as atuais formas de enfrentamento dos comportamentos em violência familiar e/ou de gênero têm-se mostrado ineficientes, uma vez que abordam a questão de um ponto de vista dualista e normativo: combatendo e punindo uns, e protegendo e vitimizando outros. Acreditamos que somente a partir da incorporação dos gêneros (homens e mulheres), considerados pela dialética proposta por Carvalho, verdadeiras transformações poderão ser alcançadas no âmbito das relações violentas de gênero. 


\section{O CAMPO CONSTRUCIONISTA E A VIOLÊNCIA}

Vimos no capítulo anterior como a questão da violência em geral e da violência de gênero em particular têm se mantido com pouca ou nenhuma alteração nos últimos 30 anos, apesar dos inúmeros programas voltados à proteção da mulher a partir dos movimentos feministas dos anos 60-70. Descrevemos o caráter dualista, de tipo vítima/agressor, com que o problema tem sido tratado, propondo a necessidade de romper com o caráter maniqueísta de compreensão do fenômeno, através da inclusão dos homens em projetos que visem facilitar a ampliação de uma rede de sentidos diversificada.

Neste capítulo, iremos definir o que entendemos por violência. Em seguida, trataremos mais detidamente dos estudos de gênero a partir do campo construcionista, naquilo que esta abordagem apresenta de mais original de nosso ponto de vista, ou seja, a desconstrução do caráter natural ou essencialista, através do qual, atos violentos ou padrões de relacionamentos entre homens e mulheres são compreendidos na cultura. Veremos também, com base na concepção desconstrutivista que, sendo os valores hegemônicos construções da e na cultura (e, portanto, de caráter mutável), podemos pensar em uma fluidez ou não fixidez de padrões, sugerindo a possibilidade de transformações nestes padrões, não limitada à expressão seja pelo ato violento, seja pela imposição de lugares hierárquicos inflexíveis. Ainda discutiremos as concepções de identidade sexual e identidade de gênero e como as construções destas se dão na cultura. 


\section{1- DE QUE VIOLÊNCIAS FALAMOS?}

Ao longo dos anos em que vimos trabalhando na coordenação de grupos, tanto de homens como de mulheres das classes populares ${ }^{17}$, constatamos a prevalência do que é designado como ideologia naturalista. Esta denominação diz respeito a um modo de organização das idéias que determina de forma quase dogmática os atributos femininos e masculinos, ou ainda, o que é considerado próprio do comportamento de homens e mulheres, como algo naturalmente dado, algo da constituição do indivíduo e que vem atrelado ou é definido pelo sexo biológico. Embora a demanda de atendimento a homens na PMFC, seja quase que inteiramente de cunho jurídico do âmbito do Direito da Família, é bastante comum que, a medida que as discussões nos grupos caminhem, verifiquemos manifestações violentas de gênero, que comumente envolvem, ofensas verbais, agressões físicas, idas à delegacia para a realização de boletins de ocorrência, ou ainda, a presença da polícia atendendo a chamados feitos pelas mulheres, vizinhos ou parentes na quase totalidade dos casos que atendemos. Comportamentos que envolvem práticas tais como: agressão física, desqualificação sistemática da/o companheira/o, negligência afetiva em relação a/o companheira/o e/ou aos filhos, negligência financeira em relação aos filhos, proibição de que a mulher exerça um trabalho profissional fora do âmbito doméstico, proibição de que mulheres tenham vida social, acusações que põem em dúvida o caráter moral da mulher, violência praticada por homens sob efeito de substâncias tóxicas (principalmente álcool), infidelidade conjugal masculina, atos violentos desencadeados por ciúme e tantos outros não são identificados nem como práticas violentas nem como atos que visam a manutenção do lugar de poder, mas como práticas naturais, ligadas a um ou outro sexo, freqüentemente consideradas necessárias para a constituição do caráter de identidade masculina, como descreve Heilborn (1999) ao referir-se aos roteiros prescritos para o gênero masculino. Para

\footnotetext{
${ }^{17}$ Anterior ao atendimento dos grupos de homens, realizamos, por alguns anos, a coordenação do grupo de mulheres na Instituição.
} 
exemplificar ao que nos referimos, dentro deste código é próprio do homem - o que em outras palavras quer dizer que é justificado - que este agrida a mulher ou destrua os bens da casa quando sob efeito do álcool. Embora, tanto homens quanto mulheres, ao relatarem fatos como estes, adotem uma postura recriminadora (não acham uma conduta valorizável ou desejável), isso não tem, contudo, um caráter de implicação do sujeito como responsável por si mesmo e por seus atos: é, antes, efeito do álcool, sendo normal que homens bebam. Como efeito complementar, tampouco as mulheres se vêem como sujeitos, com possibilidade de autodeterminação, podendo aceitar ou recusar a convivência com tal comportamento.

Este é um exemplo dentre muitos, que tem como conseqüência não só autorizar ou justificar práticas violentas e abusivas, quanto impedir que tais práticas sejam reconhecidas como violentas. Assumem um caráter de 'as agruras normais do casamento', ou 'homem é assim mesmo', ou ainda, 'minha mãe também passou por isso', impedindo que sejam questionadas uma vez que adotadas como naturais, como também apontado em outros autores (HEILBORN, 1999; MUSZKAT, M., 2003;MUSZKAT,S.,2003).

As práticas violentas de homens contra suas companheiras não se esgotam na violência física, e estão inseridas dentro de um código perpetuado na cultura, que associa estas mesmas práticas a valores à concepção de masculinidade.

Observamos também como determinados valores hegemônicos estão a serviço da manutenção da hierarquização de poderes, freqüentemente definidos como naturais. Os estudos de gênero, iniciados com o movimento feminista e amplamente teorizados desde o final dos anos 70 por cientistas sociais do campo construcionista tais como Gayle Rubin, Carol Vance, Jeffrey Weeks, Maria Luiza Heilborn, Joan Scott, contribuem de forma significativa na desconstrução deste caráter essencialista que vem justificando e perpetuando tanto a adoção de práticas violentas como o desequilíbrio de poderes nas relações conjugais e familiares. 
Assim, a adoção deste vértice se justifica por fornecer subsídios teóricos que nos permitem questionar o caráter essencialista ou natural de determinados valores e práticas culturais.

$\mathrm{Na}$ teoria psicanalítica que articularemos com a teoria construcionista acima mencionada, encontramos ao longo da obra freudiana, uma longa série de trabalhos (Os três ensaios sobre a sexualidade, 1905; Sobre o Narcisismo: uma introdução, 1914; Os Instintos e suas vicissitudes, 1915; Luto e Melancolia,1917; O Mal- Estar na Civilização,1930, e outros), que abordam a questão da agressividade, do ódio, da destrutividade e da violência (embora o termo violência propriamente dito só tenha sido usado na correspondência com Einstein, intitulada Por que a Guerra,1933). A pulsão agressiva ou o ato violento aparecem tanto como elemento fundante e constitutivo do psiquismo, como ato que inaugura a civilização e sua organização social, como propõe Freud em Totem e Tabu (1913).

Como elemento garantidor da integridade psíquica, Freud discorre sobre o desamparo fundamental inerente à condição humana e o conseqüente estado de dependência de um outro na constituição de sua subjetividade. Isso, ao mesmo tempo em que marca a intersubjetividade como da ordem do imprescindível na constituição do indivíduo, enfatizando a dependência de um outro na construção e manutenção de um si mesmo, também evidencia o peso do social - transmitido inicialmente por este outro que cuida imbuído de valores da cultura -, na construção da subjetividade e da identidade de cada sujeito da e na cultura. Assim, o sujeito é ao mesmo tempo individual e social, como lemos em Freud em Psicologia das Massas e análise do ego (1921, p.91), “a psicologia individual é ao mesmo tempo também psicologia social”.

Descreve o aparelho mental como constantemente sujeito a pressões e excitações tanto vindas do mundo externo quanto de seu interior, e a necessidade a que fica submetido em eliminar tais excitações uma vez que tem seu funcionamento regido pelo Princípio da 
Constância, princípio este que visa manter o nível de excitação do aparelho psíquico o mais baixo possível, já que o incremento de excitação é sentido como desprazeroso, tal qual postulado em seu artigo de 1911, Dois princípios do funcionamento mental.

O desprazer resultante da intensidade pulsional a que o aparelho psíquico fica submetido, é vivido como desamparo, pondo em risco a integridade do aparelho psíquico e do sujeito. Isabel Kahn Marin (2002) em seu livro, resultado de sua tese de doutorado, intitulado Violências, irá argumentar a favor do que denomina como violência fundamental, definindo-a como uma violência necessária para a constituição do sujeito, para a sua saída do princípio do prazer, condição para o surgimento do sujeito socializado. Sem esta violência, que na terminologia freudiana associa-se à castração, o indivíduo ficaria abandonado a uma intensidade pulsional insuportável cuja resultante, segundo Kahn, seria a transformação destas pulsões internas numa violência aniquiladora que impeliria o sujeito a expeli-las de forma destruidora sobre o outro. A agressividade como meio de expulsar o mau, o indesejado, é assim descrita em $O$ instinto e suas vicissitudes (1915, p.160), “pode-se asseverar que os verdadeiros protótipos da relação de ódio se originam não da vida sexual, mas da luta do ego para preservar-se e manter-se narcisicamente”. Afirma que inicialmente, são sentidos como idênticos o mau e estranho e aquilo que é externo ao ego. Freud descreve o mecanismo de projeção, como sendo inicialmente um mecanismo de preservação do aparelho mental, cujo intuito é o de procurar livrar-se, expulsar de dentro de si, sobre um outro externo, aquilo que é sentido internamente como mau e desorganizador, atendendo ao princípio norteador de funcionamento mental, o Princípio do Prazer. Com efeito, para Freud a agressividade tem duas versões, uma no interior do Princípio do Prazer, e outra a partir do abandono desta premissa básica para o psiquismo. Ainda que a agressividade seja inerente ao ser humano em ambas, estas versões resultam em concepções muito diversas para o que nos interessa. Inicialmente, na primeira teoria das pulsões, ela é pensada enquanto um elemento 
da própria sexualidade, elemento que visaria possibilitar uma apropriação do objeto sexual no caso deste não se oferecer espontaneamente. Esta primeira versão parece, de fato, se aproximar da idéia de uma "naturalidade da violência” na sexualidade masculina. Em sua segunda versão, após 1920, a agressividade se desvincula da sexualidade com o conceito de Pulsão de Morte. Nesse caso, ela adquire, contudo um caráter destrutivo apenas quando desfusionada de Eros, sendo, normalmente, garantidora da vida e da integridade psíquica quando integrada às pulsões amorosas ou de vida. Essa segunda versão da naturalidade da violência inerente a ambos os sexos, serve para compreender a própria organização vital a partir de outras bases, sendo que dificilmente pode ser invocada para atribuir uma natureza violenta de modo privilegiado ao gênero masculino. Novamente em 1921, em Psicologia das Massas e Análise do Ego, Freud assevera a importância no sentido de uma unificação dos instintos como condição de desenvolvimento, dizendo que há um “avanço irresistível no sentido de uma unificação da vida mental” (idem, p.133), tal qual haveria no mito de Platão, ao qual refere, em seu artigo de 1920, o desejo e a necessidade de fundir-se com a 'outra metade’ faltante.

Tomando como base as formulações freudianas acerca dos processos de fusão e integração dos instintos como garantidor da vida e da saúde mental, seria possível estendermos essas concepções para uma melhor compreensão quanto ao insucesso das políticas públicas vigentes, uma vez que estas se apóiam habitualmente em modelos dualistas? No mesmo sentido, é notável o modelo maniqueísta que rege as práticas de dotação de valores positivos e negativos para tratar das diferenças, dado este plenamente constatado tanto nas problemáticas relacionadas à violência de gênero, quanto do preconceito em geral. 
Uma das questões que nos colocamos é: se entendermos que uma das formas possível de resposta frente a uma ameaça à integridade narcísica seja aquela que se dá por meio do ato violento (no que este ato tem como tentativa de recuperação de poder e de resposta à frustração face à impotência), seria viável pensarmos que a transformação dos ideais culturais associados à noção hegemônica de masculinidade, -através da alteração ou ampliação dos sentidos vinculados a estes ideais- implicaria também numa modificação dos padrões nas relações de gênero? Para tanto, nos valeremos, mais adiante neste trabalho, dos artigos freudianos que tratam sobre a questão grupal, a instalação e função do ideal de ego e superego e sua relação com o narcisismo em sua articulação com os valores disseminados em nossa cultura, de forma semelhante a que fez Carvalho (2003) ao tratar do tema da violência de gênero e sua inter-relação com o universo do imaginário romântico feminino.

Uma outra questão que se nos coloca decorrente das anteriores é a de se podemos pensar a violência de gênero como manifestação da mesma ordem daquela descrita por Kahn ao relacionar a violência como resposta ao desamparo pulsional.

Ou ainda, seria cabível compreendermos atos violentos nas relações de gênero como algo da ordem das pulsões sádicas cujo caráter básico diz respeito a uma satisfação libidinal?

Identificamos distintas violências, desde aquela do marido que espanca sua mulher de forma recorrente que nos remete a pensarmos na violência da desfusão pulsional, do sadismo, onde a violência associa-se ao prazer sexual, até aquelas que permeiam as relações de maneira naturalizada evidenciadas na desigualdade de poderes.

Bourdieu (1998), referindo-se ao caráter naturalizado destas relações, nos oferece uma interessante contribuição ao dizer que, a dominação de gênero impede que tanto homens quanto mulheres possam pensar fora do esquema de dominação masculina, levando-os a interpretar essa relação como natural e assim conspirar por sua própria dominação. Descreve 
este modo de funcionamento social como esquemas não-pensados de pensamento, sugerindo um caráter inconsciente compartilhado de funcionamento (idem, p.22).

Por fim, o que justificaria essa permanência ou adesão a esquemas tradicionais de gênero e à violência a que mulheres são freqüentemente submetidas, que temos visto repetirem-se por gerações e gerações, a despeito dos esforços dos movimentos feministas e das políticas públicas destinadas a eliminação destas práticas?

Pensamos que uma análise da inter-relação das duas correntes teóricas aqui propostas - a psicanalítica e a construcionista - nos forneçam maiores subsídios no sentido de pensarmos as questões de gênero nos três níveis em que se articulam: o individual, o cultural e o social.

Evidentemente não poderemos esgotar ou abarcar essa gama diversificada de expressões violentas neste trabalho. Nossa intenção é bem mais modesta, propondo-nos a identificar e discutir as expressões desiguais de gênero, assim como se manifestam no discurso masculino dos grupos que coordenamos. Pensamos que a inclusão do vértice masculino, assim como proposto por alguns autores (GREGORI, 1993 e outros), nesta discussão, possa contribuir para uma melhor apreensão do fenômeno oferecendo um instrumental para se pensar novas formas de abordagem do problema no âmbito das políticas públicas. O aprofundamento dessa discussão será feito no capítulo quatro.

\section{2-O CONSTRUCIONISMO SOCIAL}

O construcionismo social se propõe a questionar como se produzem, na cultura, os sentidos atribuídos às condutas, comportamentos, crenças, valores, ideologias e práticas humanas, como processos que se dão dentro de um contexto histórico, social e cultural. 
Neste capítulo, procuramos explorar a noção de construção das relações de gênero, valendo-nos de autores do já citado campo construcionista - antropólogos, sociólogos, historiadores e psicanalistas - que discutem o tema dentro desta perspectiva.

Por fim, uma vez que sabemos ser imprescindível considerar características tais como sexo, gênero, raça, classe social, escolaridade, religião (e talvez ainda outras variáveis) de cada indivíduo quando se pretende fazer uma análise de suas práticas, não pretendemos esgotar ou generalizar para o universo masculino as idéias contidas neste capítulo. No entanto, como estes homens com quem trabalhamos estão inseridos, tanto quanto são coconstrutores e reprodutores desta cultura, acreditamos que a análise e os exemplos que eles nos fornecem através de suas falas possam ser representativos de uma determinada forma de pensar e das práticas adotadas nas relações conjugais heterossexuais ${ }^{18}$, nas relações parentais, bem como na interação com outros homens.

Vale, contudo lembrar que a cultura que reproduz e perpetua as relações hegemônicas masculinas de gênero, onde práticas de dominação dos homens sobre as mulheres são avalizadas, não se restringe ao universo masculino. Sem querer com isso culpabilizar as mulheres por situações de humilhação ou violência a que são com freqüência submetidas, não podemos desconsiderar que também as mulheres compartilham extensamente destes mesmos códigos e valores, contribuindo com sua manutenção. É, portanto, essencial despertarmos nosso olhar para um sujeito implicado como sujeito da e na cultura. Impedidos de olhar para a questão da violência de gênero de um ângulo que abranja ambos os gêneros, caímos numa armadilha maniqueísta que, de nosso ponto de vista, tem sido o grande obstaculizador na obtenção de melhores resultados para a transformação destes padrões de relacionamento. Voltando a Gregori (1993), esta faz em seu Cenas e Queixas, uma rica

\footnotetext{
${ }^{18}$ Explicito as relações como sendo heterossexuais, uma vez que nunca houve um caso de homossexualismo que tenha chegado a procurar a Instituição. Contudo, isto possivelmente venha a confirmar as hipóteses quanto ao que é permitido enquanto prática sexual dentro de determinado grupo onde a ideologia predominante é a de masculinidade hegemônica.
} 
descrição do trabalho realizado numa instituição paulista, fundada nos anos 80, voltada ao atendimento de mulheres vítimas de violência dentro de uma ótica feminista. Gregori realiza uma ampla elaboração que converge com nossas observações de que a simples exclusão de uma das partes do casal, e a atribuição de sentidos vitimizadores ou culpabilizantes às mulheres e homens respectivamente, têm se mostrado ineficaz no que se refere a eliminar comportamentos de tipo abusivo em relação às mulheres. Há que se considerar que as relações de complementaridade, os desejos e sonhos das mulheres em relação ao companheiro e a ligação afetiva entre eles impedem que a questão seja tratada exclusivamente sob um prisma punitivo pelas políticas públicas vigentes. Ao falar da intrigante observação de que embora as mulheres que procuravam assistência nesta instituição estivessem 'sendo ajudadas' a desenvolver sua auto-estima, se fortalecer e poder ‘se livrar’ dos companheiros abusivos, isso não acontecia. Em suas palavras: “a adesão das mulheres não é facilmente garantida, já que elas estabelecem relações de afinidade e intimidade com os homens e, sem dúvida, encontram benefícios (afetivos, sexuais, de estabilidade social e, muitas vezes, econômica) nessas relações” (idem, p.54).

Na mesma linha encontra-se o já mencionado trabalho de João Alberto Carvalho (2003), que expõe a situação de maior vulnerabilidade em que se encontram, atualmente, as mulheres com parceiros fixos em relação à contaminação pelo vírus HIV, fato também descrito por outras autoras feministas como Pitanguy (2003) e Barbosa (2003).

É, portanto, no intuito de sair de uma abordagem dicotomizada, considerando os exemplos fornecidos acima aliados à nossa experiência institucional e psicanalítica, que buscamos outras formas de compreensão a fim de nos auxiliar na promoção de mudanças nos padrões de relacionamentos de violência de gênero. Assim, voltemos aos sociólogos.

No campo construcionista, Jeffrey Weeks (1996) e Carol Vance (1995) descrevem como preocupação central do construcionismo social não o que causa uma ou outra forma de 
definição de sentidos - como por exemplo os sentidos atribuídos à homossexualidade ou a heterossexualidade- mas sim o problema de por quê e como a nossa cultura privilegia um e marginaliza outro. A que fim ou finalidade servem essas definições ou, ainda, a serviço do que elas estão.

Coloca-se em xeque o caráter essencialista de determinadas concepções que, ao serem dotadas de sentidos dados pela cultura, impõem padrões normatizadores de comportamentos que são preconizados e perpetuados dentro dessa mesma cultura, tendo como finalidade a institucionalização das relações de poder na sociedade. Ainda outras autoras feministas citadas por Monteiro (2002), como Butler e Scott, procuram discutir a desnaturalização ou desconstrução das noções de masculino e feminino através dos estudos de gênero. Conforme dito por ele, estas autoras "buscam repensar como o corpo biológico adquire identidades sociais e de gênero” (MONTEIRO, op. cit., p.247) numa crítica ao pensamento feminista clássico que pressupõe a mulher como categoria única, de forma generalizada, segundo a qual esta se encontra submetida à opressão exercida pela masculinidade hegemônica.

Sob a perspectiva dos estudos de gênero, categorias como "homem” e "mulher" devem ser entendidas dentro de seus contextos sociais e culturais, levando-se em conta não apenas a constituição biológica, mas principalmente questões sobre como se articulam o corpo biológico, o desejo sexual, e as práticas dos indivíduos, além de sua inserção dentro de um determinado contexto sócio-cultural, levando sempre em conta características como raça, religião, classe social, escolaridade, etc, (MONTEIRO,2002; PAIVA, 2000).

Referindo-se a Annamarie Jagose, Monteiro faz uma síntese esclarecedora ao descrever os estudos desconstrutivistas como aqueles que visam criticar a "naturalidade da correspondência entre sexo biológico (aquele associado ao aparelho reprodutivo, aos cromossomos), identidade de gênero (vista como representação social a respeito do sexo 
biológico) e o desejo sexual (homo, hetero ou bissexual)” (MONTEIRO, op. cit., p.248). Esta corrente de pensamento põe em questão o caráter de naturalidade, de conceitos fortemente enraizados na cultura tais como a heterossexualidade ou o lugar atribuído ao feminino em função de sua condição reprodutiva, ou seja, questiona-se tanto o lugar quanto os papéis naturalmente atribuídos a homens e mulheres em função de sua constituição biológica e de sua capacidade reprodutiva.

Voltemos a Freud (1905) onde em seu artigo Os três ensaios sobre a sexualidade, irá destacar as diferenças entre as concepções de instinto e de pulsão, retirando desta última o caráter natural da sexualidade humana. A pulsão, segundo Freud, tem como objetivo sua satisfação, admitindo, contudo, um objeto variável para tal fim. Visa à diminuição das excitações do aparelho mental, vivenciadas como desprazerosas. A busca pelo objeto que atenda à demanda da pulsão é, conseqüentemente, ao mesmo tempo interminável, permanente e inalcançável, uma vez que o objeto almejado associa-se a um objeto mítico, fantasiado, mediado pelo desejo e inspirado nas primeiras relações objetais da infância. Por este motivo, é ao mesmo tempo um objeto buscado e nunca alcançado. Este não é um ponto de menor importância quando nos deparamos com as falas dos homens de nossa amostra, que com freqüência buscam encontrar em suas companheiras, um objeto idealizado, preenchedor de suas demandas, e ao serem frustrados atribuem a falha ao objeto, disparando, como veremos nos exemplos dos extratos, acusações de caráter maniqueísta.

Ao instinto, por sua vez, vincula-se uma necessidade, cuja satisfação só é possível de ser preenchida no encontro com um objeto fixo, determinado, característica do comportamento animal. 
Encontramos em Manuel Castells (1999) uma interessante discussão sobre a forma de construção social da identidade como um processo inter-relacionado que se dá num contexto marcado pelas relações de poder.

Ele propõe três diferentes formas de origem dessa construção, as quais denomina: Identidade legitimadora, introduzida pelas instituições dominantes na sociedade, cujo intuito é garantir e expandir sua dominação sobre os atores sociais.

Este primeiro grupo seria constituído pelas instituições já legitimadas, ou ainda, por aquelas que exercem uma maior ascendência na sociedade em termos de definição de padrões e valores sociais. Carrega em si a proposta de transmissão ideológica de uma identidade padronizada, não diferenciada, ou ainda, uma identidade imposta.

A um segundo grupo, denomina-o como de Identidade de resistência, caracterizado pelo agrupamento dos atores em posições desvalorizadas e/ou estigmatizadas, ou seja, não compartilha da atribuição de sentidos sociais que se verifica no primeiro grupo. Criam, assim, um movimento de resistência aos valores hegemônicos, identificando-se entre si como um grupo de identidade política.

O terceiro grupo descrito, o de identidade de projeto, se dá "quando os atores sociais, utilizando-se de qualquer tipo de material cultural ao seu alcance, constroem uma nova identidade capaz de redefinir sua posição na sociedade, e ao fazê-lo, de buscar a transformação de toda a estrutura social” (idem, p.24).

Este é o caso de todos os movimento sociais organizados, como o feminismo, movimento negro, movimento pela legalização do aborto, de igualdade de direitos a grupos minoritários, etc, que agrupam atores sociais, inicialmente pertencentes ao grupo anterior, mas que passam a se organizar de forma a sair do lugar de exclusão. Caso sejam bem sucedidos, podem vir a ocupar o lugar definido pelo primeiro tipo de identidade - a 
institucionalizada - dando-nos, portanto, a dimensão da fluidez contida na noção de identidade; da possibilidade de transitoriedade ao longo da história do que são valores hegemônicos ou excluídos.

Consideramos este um ponto que merece ser destacado uma vez que indica como valores e padrões aceitos e/ou rejeitados na cultura podem ser alterados - o que atesta para o caráter não estático e refuta a idéia essencialista destes padrões - através de atos de resistência e projetos, como denominado por Castells, sendo assim, passíveis de transformação. Essa idéia evidencia a incongruência de se pensar nos códigos hegemônicos masculinos como códigos de valores absolutos, inalteráveis, e naturais, mas antes, ressalta sua finalidade de manutenção de poderes dominantes. Esta perspectiva admite que pensemos em ações que ampliem os códigos tradicionais pelos quais muitos dos homens da classe popular são regidos. Esses códigos, se por vezes lhes outorgam um lugar de superioridade em relação às mulheres, em outras situações - tais como quando perdem o emprego e passam a depender financeiramente da companheira - vêem-se aprisionados num lugar de absoluta solidão emocional uma vez que se vêem impedidos de atender a um modelo idealizado de masculinidade. Assim, gostaríamos de ressaltar que a crítica que fazemos ao tradicional esquema de gênero, não se deve ao que sua forma tem de tradicional mas sim à sua inflexibilidade enquanto sistema de crenças e valores.

Continuando, Castells mostra-se principalmente interessado em apresentar instrumental que nos possibilite compreender as mudanças sociais que têm levado a transformações na construção da identidade coletiva, levando assim não só a mudanças na identidade individual, como também nas formas de organização social. Discute a interrelação destas transformações com a forma de organização familiar patriarcal, que vem sendo enfraquecida uma vez que novos modelos passam a coexistir dentro de um sistema autorizado. Assistimos à mudança de uma forma de identidade legitimadora (a família 
patriarcal como única existente) e a inclusão de outras formas de estruturação familiar que passam a ser legitimadas, resultando em novas possibilidades de identidade no mundo contemporâneo. Entende que este processo vem associado à intensificação de uma diversidade de movimentos como os feministas, gays, lésbicas, sendo estes diretamente relacionados a um abalo e desmantelamento da família patriarcal. A entrada das mulheres no mercado de trabalho e a necessidade, nos dias atuais, que muitos homens têm da participação de suas companheiras no orçamento familiar incide diretamente na ideologia do patriarcalismo, que tinha como justificativa legitimadora a idéia de que o provedor deveria gozar de privilégios de dominação.

Sustenta ainda que o movimento feminista que se deu ao final dos anos 60 e começo dos anos 70, a princípio nos EUA e posteriormente difundindo-se para diversas partes do mundo, teve um caráter social transformador, desafiando o patriarcalismo e evidenciando a diversidade existente dentro de distintos grupos feministas, cujas lutas expressam seu multiculturalismo. Diz ele:

O que asseguro é que a essência do feminismo, como praticado e relatado, é a (re) definição da identidade da mulher: ora afirmando haver igualdade entre homens e mulheres, desligando do gênero diferenças biológicas e culturais... em todos os casos, seja por meio da igualdade, da diferença ou da separação, o que é negado é a identidade da mulher conforme definida pelos homens e venerada na família patriarcal (idem, p.211).

Embora o movimento feminista origine-se como movimento que recusa o lugar de opressão e submissão atribuído ao feminino pelo universo dominante masculino, João Carvalho (2003) nos relembra o que traz Bourdieu, que, questionando o caráter estático desta dominação, propõe que se a submissão não é um lugar autorizado pelas mulheres, tampouco é um modelo exclusivamente imposto pelos homens, ressaltando o aspecto dialético contido nesta relação dominado/dominador, uma vez que nem uns nem outros “dispõem para o 
pensar e para se pensar, senão de instrumentos de conhecimento que têm em comum com ele (dominador) e que não são senão a forma incorporada da relação de dominação” (BOURDIEU apud idem, p.28).

Consideramos este argumento altamente relevante uma vez que aponta para duas questões fundamentais quando se pretende abordar a problemática de gênero: ao mesmo tempo em que rompe com um sistema dualista de vítimas e opressores (no qual a maior parte das políticas públicas se sustentam), evidencia a impossibilidade de pensar-se fora do contexto histórico cultural no qual se está inserido. A reprodução, portanto, de determinados modelos de relacionamento não se dá senão pelos próprios indivíduos daquela cultura, que são, a um só tempo, produtores e produto dos valores culturais hegemônicos. Além disso, atenta, como no trabalho acima citado de Gregori, para o questionamento de uma ideologia que aprisiona às mulheres num lugar vitimizado, sendo conseqüentemente tratadas como incapazes de gerir ou ter poder sobre seu próprio destino, numa posição infantilizada.

Castells, propõe olharmos para o caráter cambiante da noção de si mesmo (de identidade), bem como dos papéis anteriormente associados a um ou outro sexo como sendo naturais, uma vez que o sistema patriarcal vem perdendo força como sistema único na sociedade contemporânea. Sugere que esta transformação traz em si uma correspondente transformação coletiva da noção de identidade das mulheres, como também uma confusão quanto ao que os homens entendem por identidade masculina, abrindo-se um leque de possibilidades identitárias que antes ficavam relegadas a grupos marginais.

Já Carvalho (2003) é menos otimista, e a nosso ver, mais realista, ao afirmar que: “apesar da observação dos avanços da mulher no domínio público como no emprego e na escolaridade, sobretudo nos centros urbanos, não se verifica uma correspondência equivalente de liberdade, autonomia e igualdade no terreno privado” (idem, p.25). 
No entanto, não discordamos da visão de Castells, sendo importante a ressalva que lembremos não ser possível tratar da questão genericamente desconsiderando os distintos modos de funcionamento dos diferentes extratos sociais.

Uma pesquisa realizada em 1999, com sujeitos de classe média, com grau de escolaridade superior na cidade de São Paulo, intitulada Os Homens, esses desconhecidos: Reprodução e Masculinidade, apontam resultados que convergem com esta argumentação de Castells no que se refere a novos arranjos entre homens e mulheres nas relações conjugais. A pesquisa evidencia o questionamento e novas formas de organização entre estes jovens casais de classe média paulistana, negociando funções e papéis que contrariam os antigos sistemas de gênero de suas famílias de origem. Contudo, como já dissemos em outra parte (MUSZKAT \& MUSZKAT, 2003), verificamos algo distinto nas famílias com as quais trabalhamos na PMFC. É sabido que as mulheres dos extratos mais pobres, sempre estiveram inseridas no mercado de trabalho fora do âmbito doméstico, sendo inclusive, com freqüência, a principal ou única fonte de renda destas famílias. Isso, no entanto, não alterou, nestas famílias as expectativas em relação aos esquemas de gênero no nível do imaginário, ou seja, embora essas famílias não se constituam segundo os modelos tradicionais de família nuclear nem tampouco obedeçam à divisão sexual do trabalho deste modelo (uma vez que nem os homens são provedores, nem as mulheres podem dedicar-se exclusivamente ao cuidado doméstico e da prole), mantém, ainda assim, na esfera do imaginário, lugares e funções que dizem respeito ao esquema tradicional hegemônico. Propusemos naquela ocasião que a manutenção destes lugares imaginários fixos poderiam estar associados “a tradução de uma manifestação simbólica em que o homem corporifica a idéia de autoridade moral do grupo, de responsável pela respeitabilidade familiar” e que seria "este fator que estimularia as mulheres a manter simbolicamente uma posição de subordinação que lhes garanta respeitabilidade” (idem, p.130), o que é também compartilhado no universo de 
representações masculinas deste extrato ao qual nos referimos. Vemos, portanto, que outros valores - como o da respeitabilidade - atuam na esfera simbólica de forma a complexizar a questão quando pensamos em discutir determinados lugares de poder, ou seja, que a subordinação feminina no âmbito da família, como também lemos em Sarti (1996), por paradoxal que seja, é a garantia de uma posição simbólica de poder dentro de um universo cuja presença masculina outorga à mulher um diferencial quanto ao seu status social. Pensamos que, esse também, seja um fator que mereça questionamento em função da contradição evidenciada entre o universo imaginário e a vivência cotidiana. No entanto, é de se destacar, como a força das representações que habitam o mundo mental dos sujeitos, quando coladas a determinados sentidos, podem perdurar como esquemas de pensamento fixos em detrimento da percepção da realidade externa.

\section{3-GÊNERO, SEXO E SEXUALIDADE NOS ESTUDOS DE GÊNERO}

Alguns termos como gênero, sexo, sexualidade, identidade de gênero e identidade sexual são discutidos por diversos autores construcionistas, com o intuito de verificar os sentidos atribuídos a eles dentro de um determinado contexto histórico-cultural.

Numa revisão da palavra “gênero” feito por Joan Scott (1995), ela descreve como seu uso, anterior ao movimento feminista, era uma variante para termos como masculino ou feminino, ou ainda para homem e mulher, de forma indistinta e sob um vértice francamente biológico. O movimento feminista, no final dos anos 60 e ao longo dos anos 70, retoma a expressão e passa a usá-la como sinônimo de feminino. Pensa-se em gênero ou luta de gênero como a luta contra a opressão de mulheres por homens. Assim, passa-se do conceito biológico de gênero masculino ou gênero feminino para atribuir ao gênero um caráter que em muito se aproxima do conceito marxista de luta de classes e de opressão de uma classe dominante (a masculina) sobre a classe oprimida (as mulheres). 
Scott descreve ainda as ampliações que o conceito sofre, deixando de ser identificado à mulher oprimida e passando a designar as relações entre os sexos: "o gênero torna-se, antes, uma maneira de indicar 'construções sociais’- a criação inteiramente social de idéias sobre os papéis adequados aos homens e às mulheres”, ou seja, é uma maneira de se referir “às origens exclusivamente sociais das identidades subjetivas dos homens e das mulheres” (idem, p.7).

A autora propõe uma definição que se apóia em duas partes,

O núcleo essencial da definição repousa sobre a relação fundamental entre duas proposições: o gênero é um elemento constitutivo de relações sociais fundadas sobre as diferenças percebidas entre os sexos, e o gênero é um primeiro modo de dar significado às relações de poder. As mudanças na organização das relações sociais correspondem sempre a mudanças nas representações de poder (idem, p.14).

Comenta a fixidez com que os sentidos simbólicos são expressos nas doutrinas religiosas, educativas, científicas e jurídicas, atribuindo aos gêneros caráter normativo calcado numa oposição binária, que “afirma de forma categórica e sem equívocos os sentidos do masculino e do feminino” (idem, p.14). Desafia, portanto, a história a contestar esse caráter de fixidez binária colada à concepção de gênero, incluindo noções como a política e referências às instituições e organizações sociais a fim de questionar um posicionamento que é com freqüência confundido com um consenso social e não como expressão de um conflito (idem, p.15).

Desta forma, conclui a autora, o uso de gênero coloca ênfase num sistema de relações que pode incluir o sexo, mas não é determinado por ele como tampouco é determinante da sexualidade (idem, p.7). 
Carole Vance, em seu artigo A Antropologia Redescobre a Sexualidade (1995), critica a atuação dos estudos antropológicos e da antropologia em geral como área que se pretende interessada em investigar as práticas e costumes sexuais dos povos mas que, sob seu ponto de vista, tem se mostrado muito reservada e até mesmo resistente no que diz respeito a desenvolver programas de estudos seriamente voltados para a questão da sexualidade humana. Atribui aos estudos dos construcionistas sociais o início de estudos mais sérios voltados ao tema. Scott e Vance descrevem como os movimentos feministas e as feministas acadêmicas passam a repensar o gênero, focando a questão de que “o que parecia um corpo (o feminino) naturalmente marcado pelo gênero era, na verdade, um produto mediado socialmente em alto grau: a feminilidade e os atrativos sexuais eram alcançados por uma persistente socialização com respeito aos padrões de beleza, maquiagem e linguagem corporal” (VANCE, 1995), segundo a qual sexualidade e reprodução ligavam-se de forma aparentemente natural a uma concepção de gênero feminino.

Os esforços feministas visavam demonstrar, a partir de estudos antropológicos de diferentes culturas, a grande variação do papel das mulheres nos diferentes grupos culturais. Assim, colocou-se em questão a ideologia predominante quanto à naturalidade da subordinação feminina, que baseada na reprodução biológica, associava gênero com sexualidade e definia padrões de comportamento.

Teresita de Barbieri (1991) descreve como os estudos feministas que visavam investigar as relações de subordinação verificaram a impossibilidade de se tratar ou compreender a questão fazendo uso de um único modelo explicativo. Reconheceram a necessidade do envolvimento e aportes das diversas áreas das ciências humanas, uma vez evidenciada a importância de considerar-se, no estudo sobre mulheres, as diferentes categorias de inserção social/cultural tais como: classe, grupo social, escolaridade, religião, idade, estado civil. A importância de considerar-se estas diversas categorias, a nosso ver, diz 
respeito ao reconhecimento de que a igualdade biológica sexual entre as mulheres não as constituem como grupo homogêneo, em igual situação de opressão ou subordinação.

Essa autora explica a origem dos estudos de gênero a partir de estudos feministas que buscavam entender como as formas de organização e funcionamento social condicionavam a situação de subordinação das mulheres. Assim, o estudo das sociedades de maneira mais ampla, incluindo-se aí estudos sobre os relacionamentos entre homens e mulheres nos diferentes tempos e lugares sociais em que estes se dão, abre caminho para o enfoque do conceito de gênero como uma categoria que corresponde ao "sexo socialmente construído" (BARBIERI, 1991). Ela cita Rubin (1986, p.29, tradução nossa), que define gênero como: “O conjunto de dispositivos através dos quais uma sociedade transforma a sexualidade biológica em produtos da atividade humana na qual se satisfazem essas necessidades humanas transformadas”.

Barbieri explica que as categorias sexo/gênero

são os conjuntos de práticas, símbolos, representações, normas e valores sociais que as sociedades elaboram a partir da diferença sexual anátomofisiológica e que dão sentido a satisfação dos impulsos sexuais, a reprodução da espécie humana e aos relacionamentos entre as pessoas em geral (1990, p.30)

É interessante a discussão proposta por ela em relação à dominação/controle do corpo reprodutivo feminino, em função do poder que este detém por sua condição reprodutiva e de continuação das gerações. No entanto, esclarece ela, o poder do corpo é um poder outorgado pelas sociedades e não imposto pelas mulheres (idem, p.32).

Não obstante, se não é imposto por elas, também não lhes passa como dado irrelevante. Observamos em nosso trabalho com grupos de homens que, se por um lado os homens se vêem com poderes no campo financeiro (não implicando que tenham dinheiro, 
mas que usam o pagamento ou não da pensão alimentícia para os filhos como instrumento de poder e retaliação contra suas ex-companheiras, mãe de seus filhos), estas por sua vez, reconhecendo o poder que lhes é facultado em freqüentemente terem a guarda de seus filhos, usam livremente desta prerrogativa no intuito de equilibrar poderes com os pais de seus filhos, por exemplo proibindo a visitação dos pais a eles. Constatamos nos homens, como fator bastante comum, o despertar de um sentimento de impotência e raiva em verem-se impossibilitados de exercer o poder sobre a ex-mulher. É freqüente atribuírem a elas toda sorte de acusações quanto à sua capacidade ou competência enquanto mães, bem como se revoltarem contra o sistema legal que tende a privilegiar a determinação de guarda para as mães. Novamente, vemos como nestas situações de frustração, os homens dispõem de poucos recursos de negociação, quando retirados da posição de poder. Tampouco mostram dispor de alternativas de elementos para pensar outras formas de exercer sua paternidade, uma vez que estão comumente identificados exclusivamente como o papel de pais provedores. Assim, se não têm dinheiro para pagar a pensão, é comum que nem mesmo visitem ou se comuniquem com seus filhos, ao passo que quando pagam, usam esse argumento como justificativa mor para que lhes seja autorizada a visita aos filhos. Algo como ‘já fiz a minha parte’. Verificamos neste exemplo, bastante comum, que os papéis de gênero atribuídos aqui a homens e mulheres, dentro de um esquema tradicional de divisão sexual do trabalho (homem provê dinheiro, mulher cuida dos filhos), carrega em si uma condição de alternância de poderes que estão na base das situações de conflito e violência entre estes casais. A inviabilidade que estas famílias encontram em equacionar as relações tradicionais de divisão sexual do trabalho com a realidade imposta por sua condição social e financeira, não só evidenciam a falência de tal sistema de crenças que povoam o universo de sentidos no imaginário, mas é também, em decorrência desta situação de impossibilidade, que é geradora de sentimentos de impotência e frustração, o que os leva a projetarem estes 
sentimentos (no sentido freudiano da projeção) atribuindo ao outro a responsabilidade por seu sentimento de fracasso.

É importante destacar, que embora as mulheres dessa classe social sejam normalmente sobrecarregadas com a criação dos filhos (uma vez que costumam ter que prover não só os cuidados necessários à criação, como também garantir o provimento financeiro das crianças), contando com pouca ou nenhuma ajuda por parte de seus companheiros, ainda assim não podemos negar que, como contraparte disto, observamos o poder que detêm em relação aos filhos e conseqüentemente em relação aos pais deles. A situação, portanto, quanto às relações de poder associadas aos papéis de gênero e como disparador de conflitos fica bastante evidente nestes casos. O não reconhecimento desses poderes impede uma avaliação mais fidedigna das relações de poder, comumente atribuídas de forma estática a homens e mulheres.

Barbieri descreve a função social exercida pelo controle da sexualidade, através de normas ou padrões autorizados de comportamento como forma de manutenção do poder sobre o corpo reprodutivo. Argumenta que a criação de mecanismos de controle que assegurem direitos exclusivos sobre o corpo da mulher é uma forma de eliminar o risco que adviria de uma autonomia das mulheres em relação ao próprio corpo. Diz ela que “controlar o corpo das mulheres leva a controlar o trabalho delas... porque poderia ser que, sem controlar a capacidade de trabalho, as mulheres teriam a possibilidade de dominar a sociedade ou exigir o reconhecimento de sua produção” (idem, p33). De fato, encontramos em outros autores a discussão que ora atribui à reprodução uma possibilidade libertadora (RAMIREZ, 2003), ora associa-a a naturalidade de pensar-se a função reprodutiva feminina como condicionante da mulher ao espaço privado, doméstico, explicando assim a subordinação feminina. Autoras feministas como Gayle Rubin (1999), irão refutar essa visão essencialista da mulher, uma vez que esta, reproduzida na cultura, seria a responsável 
por dotar todas as mulheres de uma espécie de “identidade transcultural”, nas palavras de Martha Ramirez, bem como pela manutenção de relações de subordinação das mulheres. A idéia da condição reprodutiva como fator de subordinação, mostrou-se central nas teorizações e mobilizações políticas feministas dos anos 70 (RAMIREZ, 2003).

Em seu artigo “Thinking Sex: Notes for a Radical Theory of the Politics of Sexuality”, Gayle Rubin (1999) faz um longo apanhado das práticas sexuais nas diferentes épocas da história e nos diferentes momentos sociais e culturais. Procura evidenciar o quanto as práticas autorizadas, preconizadas, proibidas ou proscritas estiveram sempre a serviço de interesses políticos. Em suas palavras: “The realm of sexuality also has its own internal politics, inequities, and modes of oppression. As with other aspects of human behavior, the concrete institutional forms of sexuality at any given time and place are products of human activity” (idem, p.143) ${ }^{19}$.

Sustenta que as formas de pensar a sexualidade não são destituídas de conflitos de interesse políticos e/ou sociais, mas ao contrário, é categórica ao afirmar que "sexo é sempre político” (idem, ibidem). Descreve, através dos diferentes momentos históricos, a maneira como padrões e valores relativos às práticas autorizadas atendiam a interesses de determinados grupos, restringindo e confinando a liberdade de expressão e práticas sexuais dos indivíduos. Como exemplo, descreve a perseguição igualmente feroz que se deu contra os comunistas e homossexuais nas décadas do pós-guerra americano. Lembra ainda as concepções sustentadas sobre os perigos da masturbação, implicando em práticas sobre os jovens para coibi-la. No Brasil, questões como aborto, uso de contraceptivos e a liberdade de escolha sexual ainda mostram-se temas bastante controvertidos, suscitando calorosos debates entre grupos que sustentam diferentes interesses e ideologias. Isto vai ao encontro do

${ }^{19}$ O campo da sexualidade também tem suas próprias políticas internas, suas desigualdades e modos de opressão. Tal qual outros aspectos do comportamento humano, as formas institucionais concretas de sexualidade a qualquer dado tempo e lugar são produtos da atividade humana. (tradução nossa). 
posicionamento da autora ao afirmar que "há momentos históricos nos quais a sexualidade é mais duramente contestada e mais abertamente politizada. Em tais períodos, o território da vida erótica, com efeito, é renegociado” (idem, ibidem).

Sem dúvida, se há uma imposição de que novos padrões ou hábitos sejam admitidos como existentes, até porque não se pode evitar sua constatação, verificamos que no âmbito das relações conjugais, na população por nós atendida, é justamente a dificuldade em se reconhecer a necessidade de renegociação a maior geradora de conflitos: à mudança de hábitos não corresponde uma mudança de expectativas.

Jeffrey Weeks (1996), outro autor de referência nos estudos de gênero, descreve a repercussão no âmbito acadêmico do surgimento da AIDS, tornando necessária a retomada dos estudos das práticas sexuais não restritos a uma abordagem médica, uma vez que essa exclusividade de enfoque implicaria no possível risco de patologização do tema e das práticas sexuais.

Weeks propõe-se a estudar a relação que existe entre o corpo - com seus órgãos, sensações, necessidades, impulsos e possibilidades biológicas - e os desejos, comportamentos e identidades sexuais.

Ele define gênero como a diferença social entre homens e mulheres, retirando deste conceito tanto o caráter biológico, que ele denomina "sexo", quanto o diferenciando de “sexualidade”, entendida por ele como uma série de crenças, comportamentos, relações e identidades socialmente construídas e historicamente modeladas. Desta maneira, entende gênero como algo que se dá através do exercício da sexualidade, sendo esta última mais ampla que o primeiro. Afirma ainda que o lugar da sexualidade é o corpo sexual ou biológico. Contudo, esclarece ele concordando com os autores aqui citados, os significados associados aos corpos masculino e feminino são altamente históricos e sociais. 
Assim como as feministas, Weeks entende a noção de gênero como a relação social entre homens e mulheres, pautada por uma relação de poder, e não uma simples categoria de análise. O poder ao qual ele se refere é o poder masculino que estabelece padrões à sexualidade feminina, definindo o que é desejável ou não. Argumenta que as definições, convenções, crenças, identidades e comportamentos sexuais não são o resultado de uma “evolução natural”, mas são modelados no interior de relações definidas de poder, de forma que a observação do exercício da sexualidade nos revela mais sobre a cultura do que sobre o sujeito (grifo nosso), tendo em vista os diversos estudos antropológicos que evidenciam a prevalência de diferentes formas de comportamento e papéis sexuais nas distintas culturas. Propõe, portanto, que o estudo da sexualidade se dê dentro de um contexto histórico.

A idéia de que o exercício da sexualidade está diretamente relacionado aos padrões de gênero, construídos em cada grupo cultural está ricamente elaborada no trabalho de Vera Paiva (2000) com jovens de ambos os sexos, diferentes classes sociais e escolaridades. A autora exemplifica, através de relatos de programas realizados com grupos de jovens, o fato de ser imprescindível atentar às questões de gênero de cada grupo em seus diferentes “roteiros sexuais”, uma vez que papéis de gênero são significativamente definidores da forma como meninos e meninas entendem suas possibilidades de exercício sexual.

Os “roteiros” ou "scripts” sexuais são definidos como as possibilidades de exercício ou práticas sexuais dentro de um repertório considerado como práticas “autorizadas”, dentro de um determinado sistema de valores, crenças e expectativas.

Os jovens, aprisionadas em roteiros de gênero preexistentes e não questionados, estarão sujeitos a exercer sua sexualidade de formas opressivas e opressoras, obstrutivas de um compartilhamento de prazer e, principalmente, se verão privados da autonomia para se exercerem enquanto sujeitos sexuais, ou seja, agentes de sua própria sexualidade. 
Desta forma, é essencial ao pensar-se na implementação de políticas públicas, não "separar a prática de quem pratica, dos sentidos atribuídos a cada contexto em que o comportamento se dá, separar a prática das identidades atribuídas ou conscientemente escolhidas” (PAIVA, 2000, p.208).

\section{4-IDENTIDADE SEXUAL E IDENTIDADE DE GÊNERO}

Como já dissemos, a construção da identidade de gênero está ligada à ideologia predominante numa determinada cultura. Refere-se aos papéis atribuídos a homens e mulheres, ou como definidos por Gagnon, Parker e Paiva, aos scripts associados aos sexos.

A expressão identidade sexual, em sua acepção anterior aos estudos de gênero, era associada ao seu correspondente biológico, homem ou mulher, tal como o termo gênero. Nos autores aqui citados, embora nos pareça clara a argumentação que evidencia a restrição imposta pelos padrões de gênero às práticas sexuais dos indivíduos, ainda assim verificamos a dificuldade em se estabelecer uma distinção clara nos diversos autores quanto a uma definição consensual dos conceitos de identidade sexual e identidade de gênero. É, com efeito, evidente a partir da leitura destes autores que há que se levar em conta nestas definições, tanto a ideologia dominante (definidora do que é permitido a um ou outro sexo) quanto os desejos e práticas de cada indivíduo, que dão a este a noção de si mesmo (mesmo que seja conflitante com os esquemas de gênero vigentes). Desta forma, pensamos ser adequado usarmos os termos identidade de gênero ao nos referirmos à construção de uma subjetividade apoiada numa vinculação do sujeito à ideologia dominante e identidade sexual para designar os desejos e práticas de um determinado sujeito, independente do sexo biológico, tampouco sendo obrigatória a coincidência com esta ideologia. Entendemos identidade sexual como a noção construída subjetivamente pelo indivíduo, aquilo que o faz reconhecer-se como um ser sexuado, dotado de desejo, que o leva a adotar determinadas 
práticas sexuais cujo intuito seja o de atender aos seus desejos. A identidade sexual, assim como a pensamos, inclui o sexo biológico, mas este não é definidor das práticas como o é nos esquemas de gênero. A identidade que constrói o indivíduo para si não necessariamente estará em concordância com as ideologias dominantes, podendo assim ser fator de opressão. A identidade de gênero, no entanto, construída dentro de "esquemas de gênero" e "esquemas de gênero oposto” (PAIVA, 1999), obriga a uma identificação com os valores adotados na cultura, uma vez que os esquemas são binários, ou seja, não admitem alternativas de identidade, impedindo que a sexualidade seja exercida em conformidade com o que é legítimo do indivíduo, próprio de seus desejos. Uma vez fora dos dois esquemas de gênero possíveis, outras formas de exercer-se a sexualidade podem resultar na construção de identidades definidas ou vividas como “desviantes”. Adotamos assim a idéia de que a identidade sexual, embora não exclua os aspectos da cultura (uma vez que as práticas sexuais, bem como os sujeitos que as praticam, estão inseridos na cultura), contém uma gama maior de possibilidades de expressão em relação às práticas, aos desejos e às condutas do que aquelas ‘autorizadas’. Desta forma, pensamos a identidade sexual como uma noção de si mesmo que garante um maior grau de liberdade ao sujeito, enquanto que os esquemas de gênero, definidores da identidade de gênero, funcionando dentro do esquema binário que lhe é próprio, inviabilizam uma diversidade de opções que possa conter as diferenças.

Encontramos outras formas de ultrapassar as restrições impostas pelos esquemas de gênero nas definições de scripts interpessoais, de Simon e Gagnon (1999) e cenas sexuais, de Paiva (2000). Esta última ressalta a diversidade de possibilidades de valores e cenários nas diferentes culturas, o que incide diretamente nas várias construções dos esquemas de gênero.

Para tratar da "falta de congruência entre cenários abstratos e situações concretas" (GAGNON, 1999, p.29), é necessário que se criem scripts interpessoais. Citando o autor 
(idem, p.29), “este é um processo que transforma o ator social, de um mero ator, para ser também, parcialmente, o autor ou adaptador, dando forma aos cenários culturais relevantes e assim transformando-os em scripts de comportamento em contextos específicos”. (tradução nossa)

Vera Paiva usa a expressão cenas sexuais como termo que envolve não só a cena em si, mas todo o contexto cultural e pessoal que viabiliza que determinada conduta se dê da maneira que se dá. Dito de outra maneira, o comportamento sexual dos sujeitos não pode ser pensado de forma descontextualizada. É preciso levar em conta, como ressaltam os autores já mencionados, os diversos aspectos de inserção do sujeito, tais como classe, educação, raça, idade, grupo cultural.

Gagnon descreve três níveis de scripts sexuais para se pensar como se estruturam para cada sujeito as vivências relacionadas às questões de gênero e sexualidade: cenários culturais, interpessoais e intrapsíquicos, que variam grandemente não só em função das diferentes organizações sociais ou culturais, como também de indivíduo para indivíduo em cada possibilidade de cenário que se apresente.

Ele categoriza as sociedades como paradigmáticas e pós-paradigmáticas, sendo as primeiras aquelas em que há uma grande quantidade de valores e sentidos compartilhados. É um tipo de organização com menor diversidade de significantes e, portanto, mais restrita no que diz respeito a significados. A pós-paradigmática, por sua vez, diz respeito a uma forma de organização social mais diversificada, na qual é possível identificarmos uma maior liberdade na atribuição de significados, propiciando aos sujeitos exercerem-se dentro de uma gama maior de possibilidades.

Uma idéia semelhante a esta, no que se refere ao indivíduo, é apresentada por Sennet (2000). Ele define o que entende por uma identidade fraca, aquela em que o sujeito rigidamente se apega a valores e imagens fixas de si mesmo, não podendo reformulá-las, e 
como identidade forte, aquela em que o sujeito se vê capaz de revisar as circunstâncias e adaptar-se a essas mudanças sem prejuízo à sua noção de si mesmo. A impossibilidade, seja por motivos culturais, de preconceitos, de determinadas estruturas mentais patológicas ou de idealização narcísica, de alterar a noção que se tem de si mesmo, é um fator aprisionador e impeditivo do poder narrar-se em construções alternativas mais gratificantes para o sujeito. A estas idéias que se apresentam tendo um caráter rígido, e que são veiculadas e compartilhadas na cultura tanto por homens como por mulheres, Sennet as denominou como 'mitos controladores', por exercerem um poder controlador de comportamentos e papéis, de forma estereotipada. Não só aprisionam mulheres em posições passivas, dependentes do sexo masculino, muitas vezes impedidas de atuarem de forma igualitária no mundo público, garantindo seus próprios interesses (uma vez que estão designadas ao mundo privado), como também aprisionam os homens no papel de provedor, responsável pelo bem estar e sustento das mulheres e crianças, legislador, cujo âmbito de ação se dá na esfera pública, excluindo-o no mais das vezes do contato com o mundo doméstico, sob pena de ver-se desmoralizado em sua identidade masculina.

Pensamos que, embora o mundo ocidental contemporâneo se caracterize por uma enorme diversidade em termos culturais, de valores e de sentidos - o que nos leva a pensar numa sociedade pós-paradigmática-, vemos no trabalho realizado por Paiva que, para se trabalhar as cenas ou scripts sexuais sem ignorar os esquemas de gênero, é fundamental que se considere cada grupo cultural dentro de suas especificidades.

Neste sentido, não se pode generalizar o conceito de sociedade, mas sim considerar as diferentes variáveis de inserção dos indivíduos para que se possa identificar um maior ou menor grau de sentidos compartilhados. Da mesma forma, não se pode pensar em implementar políticas públicas se não levarmos em conta os diferentes cenários bem como os scripts definidos para os gêneros dentro de um determinado contexto histórico, social e 
cultural. Portanto, para que seja possível desafiarem-se roteiros rígidos e aprisionadores para homens e mulheres no que diz respeito a gênero, é fundamental que estes sejam conhecidos e considerados, e não ignorados.

Se, como sustentam os diversos autores, os esquemas de gênero ou a dimensão de gênero é algo construído social, histórica e culturalmente, com base nos valores predominantes numa determinada cultura em determinado momento histórico, podemos então pensar nesses conceitos (gênero, identidade de gênero, sexo, sexualidade, etc) como concepções que admitem sua “desconstrução”. A mudança de valores e normas na cultura implica conseqüentemente numa transformação dos sentidos de valor atribuídos aos diversos conceitos. Estes não são meras definições de palavras, estáticas como palavras num dicionário (que também tem certo grau de fluidez), mas são, antes de tudo, um desenho dos valores sociais predominantes, de como se definem as relações de poder.

Se pensarmos que definições têm um caráter temporal e que atendem a interesses dominantes, isso justifica pensarmos que projetos ou valores de grupos minoritários possam passar de meras resistências (no sentido dado por Castells) a valores compartilhados ou, ao menos, tolerados. Poderes institucionalizados representam a dominação de alguns e a correspondente opressão de outros que, conseqüentemente, têm que se adaptar a uma ideologia predominante e valorizada ou então ficar relegados a um lugar de exclusão, a fim de evitar conflitos identitários com seus próprios ideais.

Em nosso trabalho com grupos de homens, observamos que estes, tendo pouco poder na esfera pública em função da precariedade de recursos culturais, sociais e econômicos de que dispõem, buscam exercer este poder no âmbito familiar, de forma a compensar sua falta de poder no âmbito externo ao doméstico. Observamos como o que entendem como sendo atributos do universo masculino ou feminino, está fortemente marcado por uma concepção tradicional de gênero, segundo a qual papéis, funções e comportamentos são pré-definidos 
dentro de um padrão hegemônico masculino, e onde o não cumprimento do padrão esperado de comportamento compromete sua identidade de gênero, diretamente associada à noção de masculinidade.

A construção e manutenção de uma identidade de gênero, seja ela masculina ou feminina, está diretamente relacionada a pré-conceitos quanto ao que é desejável, social e culturalmente, de homens e mulheres, sendo estas crenças compartilhadas por ambos os sexos dentro de determinados subgrupos culturais. O desejo de ser reconhecido como um homem de valor, viril, sexualmente capaz, poderoso, ou de uma mulher ser valorizada como mãe, boa esposa, sexualmente moderada, que “se dá ao respeito”, são desejos calcados no anseio de ser valorizado. Esse tema será discutido no capítulo 4, onde articularemos como padrões valorizados na cultura se confundem com os desejos dos indivíduos, adquirindo uma força controladora de padrões de comportamento.

\section{5- A CULTURA NA DEFINIÇÃO DE PADRÕES DE IDENTIDADE}

Assim como o merchandising é capaz de “vender” uma identidade desejável a quem adquirir tal ou qual objeto, ou vestir esta ou aquela marca, também as crenças ou ideologias veiculadas pelos padrões de gênero “prometem” a construção de identidades desejáveis.

A promessa de que determinado comportamento sexual possa ser atribuído ao masculino como “garantidor” de masculinidade hegemônica, poder e virilidade, é freqüentemente aprisionante, não possibilitando a estes homens que se expressem de forma mais livre e mais em consonância com suas vivências e anseios pessoais. Sendo assim, podese pensar que a identidade feminina ou masculina, é 'contaminada' por uma ideologia daquilo que é ‘vendido’ como desejável em termos de identidade de gênero. 
Desta forma, por exemplo, comportamentos violentos por parte de homens em relação às suas companheiras justificam-se na medida em que o sentimento de humilhação não pode ser admitido como algo do universo masculino.

A resposta violenta visa, com freqüência, o resgate da auto-estima através de uma demonstração de poder sobre a mulher, condição esta entendida como essencial e natural para a manutenção da virilidade e masculinidade dentro do sistema de valores aqui discutido.

Da mesma forma, a crença de que filhos são atribuições da mãe, ou a idéia de que o sustento financeiro é atribuição masculina, não só aprisionam homens e mulheres em lugares fixos, como também a impossibilidade de atender a estas demandas pelas dificuldades inerentes à condição social destas famílias cria ilhas de isolamento de comunicação e afeto entre homens, mulheres e seus filhos (que são, não raro, abandonados por seus pais, já que muitos destes acreditam não poder contribuir com nada além de dinheiro, de que não dispõem).

Consideramos que a rígida divisão sexual de trabalho, aprisiona tanto homens quanto mulheres a uma condição de "insuficiência”, onde o que compartilham é a precariedade em proverem seus filhos do cuidado necessário. Assim, o que constatamos é um movimento de acusações mútuas, em que cada um procura atribuir ao outro o motivo de sua precariedade. Homens e mulheres, aprisionados em papéis fixos, não podem vislumbrar novos arranjos de cuidado com os filhos que não estes definidos numa cultura hegemônica masculina.

Embora a “desconstrução” destes papéis seja um dos temas com os quais trabalhamos na instituição, ainda são muitos os casos em que a impossibilidade de mudança destes valores culturais se apresentem como fortes impedimentos para que sejam feitos acordos mais igualitários entre homens e mulheres no que diz respeito à vida cotidiana, ao cuidado com os filhos, ou nas separações dos casais atendidos na PMFC. 
A isto se agrega também à posição “oficial” do juiz, que costuma atribuir aos homens a obrigação do sustento financeiro, e os ameaça com prisão no caso de não se comprometerem. Se por um lado o juiz entende que muitos homens se abstêm de qualquer cuidado com seus filhos, eximindo-se de suas responsabilidades quanto a seu comportamento reprodutivo (como algo concernente exclusivamente às mulheres), por outro reforça uma idéia de que o único aspecto da paternidade que concerne ao homem é o dever de honrar com os compromissos financeiros.

Essa postura, supostamente aliada às mulheres, na verdade as onera ainda mais, pois cria um abismo entre homens e mulheres pelo qual os primeiros se sentem espoliados e queixam-se de uma atitude "interesseira” por parte das mulheres, enquanto que estas se sentem sobrecarregadas com o cuidado exclusivo de seus filhos.

É interessante questionarmos se o sistema judiciário, o Direito em termos gerais, está preparado para lidar com questões de âmbito humano, uma vez que se apóia num modelo maniqueísta de deveres e direito ${ }^{20}$.

Todos nós, nos diferentes sub-grupos aos quais pertencemos, sejam eles sub-grupos sociais, intelectuais, profissionais, acadêmicos, etc, estamos submetidos aos valores ditados por estes grupos, com os quais nos identificamos.

O desejo de ser valorizado e amado é um desejo, segundo Freud, presente no ego. Descreve a submissão do ego às demandas do id, submetido à observância do superego e a serviço do ideal do ego e dos valores da cultura. Deve permanecer em bons termos com o id, atendendo também às prescrições da realidade. Nas palavras de Freud (1923, p. 73):

\footnotetext{
${ }^{20}$ Embora tenha havido mudanças no atual Código Civil equiparando direitos e deveres dos pais em relação aos filhos, verificamos que às mudanças das leis não correspondem a mudanças nas práticas. Quem pratica a lei, com freqüência o faz reproduzindo o sistema binário de gênero que aqui destacamos.
} 
Para com as duas classes de instintos (de vida e de morte), a atitude do ego não é imparcial. Mediante seu trabalho de identificação e sublimação, ele ajuda os instintos de morte do id a obterem controle sobre a libido, mas, assim procedendo, corre o risco de tornar-se objeto dos instintos de morte e de ele próprio perecer. A fim de poder ajudar desta maneira, ele teve que acumular libido dentro de si; torna-se assim o representante de Eros e, doravante, quer viver e ser amado.

Ou ainda, em O mal-estar na civilização, postula o desejo de ser amado, não como um desejo de ordem afetiva como pensamo-lo no âmbito do senso comum, mas sim ligado ao temor imposto por uma ameaça de desamparo em função do abandono dos pais, ou de seus representantes na idade adulta, a cultura. O mau, assim, para o ego é aquilo que representa uma ameaça à integridade do mesmo, e é a isso que Freud denomina 'a perda do amor’. Risco para o ego é aquilo que leva ao desamparo, condição sempre presente no ser humano (idem, p.147).

É com base na identificação que temos com determinados grupos que forjamos também nossas identidades pessoais. A impossibilidade do sujeito em poder identificar-se com aquilo que valoriza, leva-o a sentir-se desvalorizado. Podermos manter a dimensão de que valores não têm caráter absoluto e que podem ser questionados cria condições para que tais valores não se tornem impeditivos de um desenvolvimento mais pleno e gratificante para cada indivíduo, mas sim que sejam construídos em consonância com suas necessidades pessoais, dentro de um princípio ético e humano. $\mathrm{O}$ aprisionamento naquilo que denominamos de identidades desejadas, como são as identidades de gênero, comprometem a condição do sujeito de exercer-se enquanto agente de seu próprio destino e ter uma mente própria, vivendo uma identidade pessoal ‘forjada’ 


\section{MATERIAL E MÉTODOS}

Neste capítulo descreveremos mais detalhadamente o procedimento utilizado para a seleção dos entrevistados e participantes dos grupos de homens cujas falas iremos analisar, num subitem denominado Descrição da Amostra. Em documento anexado no final desta dissertação, encontra-se uma breve descrição dos 5 participantes do grupo focal realizado ao final de quatro encontros e os motivos que os levaram a procurar a PMFC. No subitem Coleta de Dados, também descreveremos como a coleta dos dados utilizados foi realizada.

Em seguida, no subitem Metodologia, especificaremos a metodologia utilizada e justificaremos nosso interesse pela adoção de uma compreensão psicanalítica na realização da análise da fala dos participantes da pesquisa.

Por último, no subitem Quatro Sessões, será descrita uma seqüência de quatro sessões de discussão dos grupos de homens, com as falas dos participantes e as minhas, que coordenei os grupos. Estas quatro sessões serão entremeadas por comentários feitos a posteriori, elucidando o tipo de análise e compreensão que fiz a partir destes encontros. Uma elaboração mais pormenorizada das falas será feita em capítulo posterior, onde abordaremos o discurso do ponto de vista dos estudos de gênero e de uma leitura psicanalítica.

\subsection{DESCRIÇÃO DA AMOSTRA}

A amostra é composta de homens, residentes na cidade de São Paulo, cuja renda não ultrapasse cinco salários mínimos, sendo, portanto, pertencentes aos extratos mais pobres da população. No próximo subitem, De quais homens falamos, apresentaremos uma descrição mais elaborada do grupo social e cultural a que estes homens pertencem, a fim de identificarmos o universo que pretendemos pesquisar. 
A faixa salarial referida é determinada pela Instituição em virtude de convênio existente com a Procuradoria de Assistência Judiciária de São Paulo.

Os homens atendidos chegam à PMFC por diversas vias: indicação de conhecidos que já tenham sido atendidos na mesma, pelas Delegacias da Mulher, delegacias comuns, Fóruns, oficiais de justiça, por encaminhamento feito pela Procuradoria de Assistência Judiciária (PAJ), ou encaminhados por outros serviços de atendimento jurídico gratuitos da cidade de São Paulo, como as universidades. Há os que vêm espontaneamente, seja porque leram alguma reportagem, seja porque assistiram a algum programa veiculado pelos tradicionais meios de comunicação, ou, ainda, há aqueles que tocam a campainha por terem recebido informações, no bairro, sobre o tipo de atendimento realizado pela PMFC.

As questões que os trazem à Instituição são em sua grande maioria relativas ao Direito de Família, uma vez que a PMFC, além do atendimento psicossocial, garante atendimento jurídico gratuito, sendo este último o maior atrativo para a população que nos procura.

Estes homens encontram-se envolvidos em alguma espécie de conflito, seja com suas atuais ou ex-companheiras, seja com seus filhos ou seus pais, ou com a justiça no âmbito do Direito de Família. Muitos vêm em busca de separação, regulamentação de guarda e visita de filhos, problemas com pensão alimentícia dos filhos, reconhecimento de paternidade, conflitos conjugais.

Embora o motivo da procura pela Instituição não se mostre de início como algo relacionado à violência de gênero, ou seja, a demanda não é colocada nestes termos, mas em termos jurídicos, ainda assim fomos, ao longo dos anos de trabalho, verificando a intrínseca relação existente entre conflitos familiares e as questões relativas a gênero. A maior parte dos homens, que nos procuram, sentem que uma espécie de injustiça lhes está sendo feita quando, por exemplo, suas ex-companheiras exigem que se regulamentem juridicamente as questões referentes aos filhos em comum. Muitos se sentem humilhados e é freqüente se expressarem 
de maneira bastante hostil ao se referirem às ex-companheiras, evidenciando uma compreensão sobre o que lhes acontece apoiada numa concepção de tipo: certo/errado, justo/injusto, bom/mau. Isso poderá ser acompanhado na descrição das sessões que seguem, pela fala dos participantes ${ }^{21}$.

\subsubsection{O funcionamento do grupo ${ }^{22}$}

O grupo de reflexão de gênero masculino tem encontros semanais de 2 horas de duração, durante 4 semanas , com uma participação variável de 3 a 15 homens. O número de sessões foi por nós (da Instituição) determinado como um tempo que se considerou minimamente necessário para poder-se desenvolver a reflexão a respeito dos temas que abordamos nestes encontros. É também um espaço voltado ao exercício de técnicas de comunicação, visando à facilitação dos encontros de mediação com a parte contrária, e a capacitação para a negociação de acordos mutuamente satisfatórios.

A determinação quanto ao número de grupos de que cada um deve participar, embora, do nosso ponto de vista seja ainda insuficiente, considerando-se a quantidade de temas que nos propomos a abordar e tendo em vista a possibilidade de uma reflexão mais frutífera sobre os mesmos, foi, ainda assim, uma solução viável encontrada para que o processo total de atendimento na Instituição não se prolongasse demais. Outro dado relevante que determinou a escolha do número de sessões foi o fato de que estes homens apresentam dificuldades de disporem, de maneira sistemática (semanalmente), de um horário para os encontros em razão de seus compromissos de trabalho ou de procura pelo mesmo, ou, ainda, pelo custo financeiro

\footnotetext{
${ }^{21}$ A Instituição atende homens e mulheres, sendo que a população feminina que nos procura, diferentemente da masculina, vem também por questões do que é normalmente denominado como violência doméstica, ou seja, atos de agressão física praticados pelo homem contra sua companheira. A população masculina não traz esta queixa explicitamente formulada e pensamos que isso não seja algo casual. Entendemos que este comportamento se coaduna com os modelos hegemônicos masculinos que procuramos destacar neste trabalho.

${ }^{22}$ Uma grande parte do que se lerá aqui em relação ao funcionamento dos grupos está descrita em artigo da autora, intitulado Novas práticas na abordagem de gênero e violência intrafamiliar, que se encontra no livro Mediação de Conflitos: pacificando e prevenindo a violência. (MUSZKAT, S., 2003).
} 
que representa o gasto com transporte. Além disto, ao serem informados do processo pelo qual deverão passar, com freqüência expressam alguma oposição por considerarem ser um tempo longo e pelo desejo de resolverem de maneira imediata seus problemas ${ }^{23}$. Entendemos este desejo como um tipo de funcionamento culturalmente impregnado, de cunho assistencialista, no qual a expectativa é a de que a Instituição se responsabilize por solucionar suas questões pessoais sem que eles tenham de se envolver de forma mais ativa nas mesmas ${ }^{24}$. A proposta de trabalho da PMFC é de que, ao longo do processo, eles possam desenvolver um instrumental que lhes possibilite se apropriarem de suas problemáticas como sujeitos, responsabilizando-se por seus destinos.

Um último fator a ser considerado na escolha do número de sessões foi o de atender às demandas de nosso convênio, que estipula um número mínimo de atendimentos por mês. Um número maior de sessões, portanto, inviabilizaria o cumprimento de tal acordo, uma vez que o tempo de atendimento de cada usuário seria estendido. Consideramos, contudo, importante ressaltar que seria desejável uma duração maior dos grupos, o que também é muitas vezes verbalizado pelos participantes após o término dos encontros, o que, em nosso entender, vem corroborar nossa impressão quanto à falta de serviços públicos de atendimento voltado às necessidades da população masculina de baixa renda. Como se verá nas sessões de grupo relatadas, a presença nos grupos não se dá sempre de maneira seqüencial, fazendo com que seja comum haver um novo participante num grupo onde outros estejam terminando. Se por um lado, isso representa uma dificuldade a mais no sentido de se desenvolverem atividades durante os encontros, de acordo com um pressuposto de que ao seguirem juntos estaria

\footnotetext{
${ }^{23}$ Os encontros em grupo são a $3^{\text {a }}$ etapa do processo de atendimento da Instituição. Passam inicialmente pelo serviço social, em seguida por um grupo de triagem cuja finalidade é prestar esclarecimentos jurídicos, verificar urgências de cunho legal e descrever o processo de atendimento da Casa, sendo coordenado por um/a assistente social e um/a advogado. A próxima etapa constitui os grupos de reflexão (foco desta dissertação) e, por último, eles são encaminhados para mediação ou para atendimento jurídico propriamente dito, quando a primeira é inviável. É um processo que tem um tempo mínimo de dois a três meses de duração.

${ }^{24}$ Na já mencionada pesquisa sobre metodologia realizada na PMFC em conjunto com a UNICAMP, verificouse um dado interessante: o número de desistentes reduzia-se drasticamente durante e após a passagem pelos grupos, evidenciando um envolvimento nesta atividade, por parte dos homens, e contribuindo para a alteração de uma postura inicial de oposição às etapas do processo.
} 
garantida uma maior homogeneidade de desenvolvimento entre os participantes, por outro, há que se considerar não apenas as dificuldades pessoais de cada participante em atender a esta seqüência proposta, quanto à impossibilidade de garantir tal hegemonia, ainda que todos sigam conjuntamente a seqüência dos grupos. O que é notadamente favorecido quando de uma presença mais seqüencial é a vinculação que se dá entre os participantes e uma história comum que vai sendo construída ao longo dos encontros. É comum apontarem a falta de um ou outro colega, não no sentido da denúncia, mas como uma ausência que se faz presente; a constatação da falta de alguém que é sentido como pertencente a este espaço comum construído entre eles. Constata-se a construção do laço emocional, por meio de um processo de identificação entre estes homens, fator característico nas formações de grupos, assim como descreveu Freud (1921) em Psicologia de Grupo e Análise do Ego. Em suas palavras:

A identificação pode surgir com qualquer nova percepção de uma qualidade comum partilhada com alguma outra pessoa que não é objeto do instinto sexual. Quanto mais importante essa qualidade comum é, mais bem sucedida pode tornar-se essa identificação parcial, podendo representar assim o início de um novo laço (idem, p.136).

Segundo Freud, o grupo se apresenta como um organismo que tem uma representação psíquica próxima das estruturas de ideais de ego, contendo em si grande potencial transformador sempre que se puderem questionar padrões estabelecidos de forma idealizada. Sendo assim, pode-se pensar que, da mesma forma que o olhar alheio - do outro - em seu caráter de espelhamento do sujeito, possa ter um efeito cerceador (em falas do tipo "os vizinhos ficam falando" que veremos nos relatos adiante), o compartilhamento de experiências e a constatação de que outros homens vivenciam situações semelhantes são, muitas vezes, propiciadores de uma atitude mais benevolente e menos crítica entre os participantes, alterando-se, assim, no interior do grupo, a adesão a valores rígidos de comportamento tidos como masculinos. 
Freud (1914), em seu artigo sobre o narcisismo, descreve o surgimento do ideal do ego como instância separada do ego e herdeira do narcisismo original. O ideal do ego é o substituto do narcisismo perdido da infância, sendo a permanente busca em atingi-lo uma tentativa de recuperar o momento mítico, pleno, de ego ideal vivido com a mãe. Nas palavras de Freud (idem, p.111, grifo nosso), “e quando ao crescer (o indivíduo) se vê perturbado pelas admoestações de terceiros e pelo despertar de seu próprio julgamento crítico, de modo a não mais reter aquela perfeição, procura recuperá-la sob a nova forma de um ideal do ego”. Entendemos a referência a terceiros, feita por Freud, como aquilo fora do sujeito, do âmbito do social e cultural, que é transmitido ao sujeito, impondo-se como normas ou expectativas cujo alcance 'garantiria' a recuperação do narcisismo perdido. Do mesmo modo, o elemento crítico se encarregaria de vigiar o ego para que este não se desviasse da meta de alcançar o ideal de ego. Assim, os valores veiculados no interior de grupos, sendo idealizados, agem de forma normatizadora sobre estes, ditando (de maneira inconsciente) regras de funcionamento para os membros deste ou daquele agrupamento.

É ainda importante destacar o poder de coesão e de normatização de padrões imposto pelo grupo, uma vez que este, imbuído da função de 'orientador rumo ao ideal de ego', determina valores associados a este ideal. Assim, num dado grupo, os indivíduos tenderão a aproximarem-se destes valores sendo que o afastamento destes padrões implicará no risco de distanciamento de seu narcisismo original, de seu estado de perfeição almejado.

Em relação a procedimentos de funcionamento do grupo, adotamos como norma institucional, que um participante será desligado deste após duas faltas consecutivas sem nenhuma justificativa. Ainda assim, é prática comum da Instituição tentar, por meio do trabalho das assistentes sociais, um contato com o usuário que falta, a fim de verificar-se o motivo das mesmas e certificar-se do interesse do usuário em prosseguir no atendimento da PMFC. 
A passagem pelos grupos é obrigatória a todos os que buscam o serviço da Instituição, sendo assim uma das etapas do processo de atendimento da Casa.

O trabalho com os grupos tem como objetivo estimular discussões que possibilitem a reflexão sobre temas variados, tais como a condição masculina, seja na família, seja no âmbito cultural, a violência de gênero, a naturalização da violência, assim como concepções adotadas na cultura na definição dos papéis de gênero, sexualidade, relações conjugais, relações parentais, separação, conflitos, relações familiares, além de apresentar-se como espaço aberto para qualquer assunto trazido pelos participantes relativo às suas experiências de vida. Este trabalho tem ainda como objetivo proporcionar um espaço onde possam ser prestados alguns esclarecimentos e orientações básicas de cunho social e legal, ser verificada a necessidade de se fazerem encaminhamentos a outros serviços de atendimento da rede pública, serem identificadas situações emergenciais dos usuários, seus filhos e companheiras, ser avaliada com maior cuidado a situação vivida por cada participante e serem identificadas possíveis urgências no âmbito da violência intra-familiar, a fim de garantir-lhes o atendimento necessário conforme um princípio de cidadania e direitos humanos.

A coordenação do grupo é feita em dupla, sendo uma coordenadora principal do sexo feminino e um assistente masculino. Além destes dois técnicos, ao longo dos quatro encontros que serão descritos neste trabalho, havia a presença de duas pesquisadoras do sexo feminino, que anotavam, sem falar, o desenrolar dos encontros, com a maior precisão possível.

O fato de a coordenadora ser mulher (e o assistente homem) não é fato desprezível, embora não seja possível se determinarem completamente os impactos deste dado. Deve-se ter em mente, contudo, que estes homens procuram a Instituição por motivos que, na grande maioria dos casos, se devem a intensos ou violentos conflitos com uma mulher, seja ela a atual, ex, ou eventual companheira. Chegam numa postura bastante adversarial em relação às 
mulheres, identificando estas com freqüência como as causadoras de uma situação pessoal que entendem como injusta. Ainda, o predomínio de um tipo de compreensão das relações entre homens e mulheres, fortemente ancorado numa concepção hegemônica de gênero, levaos a se ressentirem de uma perda de lugar de autoridade e poder na constelação familiar e social, vendo-se submetidos a terem de levar seus casos ao âmbito de ações judiciais, o que é amiúde significado como humilhação pessoal. Não podemos, portanto, desconsiderar que o encontro no grupo, sob uma coordenação feminina, em certa medida reproduz uma situação hierárquica invertida em relação aos padrões de gênero vigentes. Soma-se a isso o lugar do assistente masculino, submetido à coordenação de uma mulher.

Bourdieu (1993) diz, acerca da pesquisa social, que embora não seja uma relação semelhante às "trocas de existência comum, já que tem por fim o conhecimento, ela continua, apesar de tudo, uma relação social que exerce efeitos” (idem, p.694). Embora o intuito do trabalho com grupos não seja propriamente a pesquisa em moldes convencionais, em que há um entrevistador e um entrevistado, as elaborações deste autor sobre o que entende por um caráter intrusivo, em que a arbitrariedade do entrevistador - uma vez que é ele quem estabelece o funcionamento da entrevista - e em que se evidenciam diferenças de variadas categorias entre o coordenador e os participantes do grupo, não devem ser ignoradas. (idem, ibidem). Há que se considerar a dessimetria social, de hierarquia dentro do grupo, de sexo, de capital intelectual e simbólico, apenas para citar os mais evidentes. Ainda que seja difícil medir o nível de interferência produzida por estas dessimetrias, uma vez que não estamos fazendo um tipo de investigação pautada em análises quantitativas, não podemos ignorar sua existência nem tampouco procurar negá-las na interação com os participantes, uma vez que isto levaria a uma troca que, justamente, se opõe ao que nos propomos a desenvolver neste trabalho: a dotação de sentidos que instrumentalizem os sujeitos para vivências mais 
harmoniosas entre um dentro e um fora de seu mundo de representações ${ }^{25}$. No entanto, a novidade que é a experiência vivida nestes grupos, levando-se em conta exatamente essas diferenças citadas, pode resultar numa mudança em relação a concepções rígidas no que diz respeito a trocas possíveis entre homens e mulheres, que são, em geral, experimentadas com surpresa e entusiasmo. É comum, ao final dos quatro encontros, os participantes se despedirem de maneira nitidamente afetuosa, expressando agradecimento pela experiência vivida, como veremos num dos relatos aqui descritos.

Vale lembrar um dado interessante relativo a que, embora os homens atribuam às mulheres o motivo de suas agruras e tenham em relação a estas um modo de funcionamento predominantemente projetivo - no sentido descrito pela psicanálise -, é freqüente que encontrem nas figuras femininas, em especial em suas mães (e às vezes em alguma amiga), as únicas confidentes. Este fato possivelmente se justifique em razão de que o risco de se verem ridicularizados por suas fragilidades seja maior em relação aos homens, como veremos adiante em seus relatos, fazendo das mulheres personagens menos ameaçadoras. Essa é uma hipótese que levantamos e que se ajusta a nossa observação nos encontros em grupo, uma vez que o fato de a coordenadora ser mulher não tem impedido que a maioria dos homens que participam logo se sintam bastante à vontade para expressar-se de forma livre e descontraída, sem indícios de competitividade em relação à mesma.

\subsection{COLETA DOS DADOS}

A coleta dos dados deve ser distinguida em três tempos: o primeiro, e menos sistemático dos três, é aquele que aparece ao longo deste trabalho quando são usados exemplos de falas ou descrição de casos atendidos na Instituição, e que não estão contidos

\footnotetext{
${ }^{25}$ A impossibilidade de vivências harmônicas daquilo que é interno e externo, baseando-se na necessidade de atender a ideais culturais, será tema discutido ao longo de todo o trabalho.
} 
num espaço temporal delimitado, mas foram extraídos de anotações nossas ao longo dos anos de trabalho.

O segundo modo realizou-se num espaço temporal delimitado de quatro semanas consecutivas, com atores mais ou menos fixos, assim como explicado anteriormente em Funcionamento do Grupo. Durante este período, os grupos foram observados por duas pesquisadoras que anotavam por escrito, de modo manual, cada sessão, o mais integralmente possível $^{26}$. A descrição das sessões aqui apresentadas foi construída com base em três observações: aquelas feitas pelas pesquisadoras, junto com as nossas observações e lembranças destas mesmas sessões. O documento final produzido é, assim, o resultado da integração destes três relatos, ao que, posteriormente, fomos agregando nossos comentários e análises, como se verá.

Há ainda uma terceira fonte de referência da qual serão usados apenas extratos de falas. Essa fonte é a transcrição feita a partir da gravação de um grupo focal realizado ao final dos quatro encontros, como parte da pesquisa realizada em associação com a Unicamp, com cinco homens que concordaram em participar deste grupo. Como este grupo focal se deu ao final de um dos grupos regulares, alguns dos homens não dispunham de tempo para o próximo encontro. O grupo então se formou com um número que se considerou suficiente para tal avaliação. O grupo focal teve como finalidade realizar uma avaliação do atendimento da Instituição pelo qual haviam passado até aquele momento, tendo como ponto de referência a opinião dos usuários. Não incluiremos nesta dissertação a descrição integral desta entrevista por julgarmos que seria exaustivo para o leitor e fugiria de nosso propósito, que é exclusivamente voltado ao trabalho nos grupos masculinos. Interessa-nos saber o que pensaram sobre a experiência vivida nestes grupos: a troca de experiências pessoais num

\footnotetext{
${ }^{26}$ Durante a elaboração desta dissertação, realizou-se uma outra pesquisa na Instituição, com financiamento da Fapesp e Prosare, cuja finalidade era a de avaliar integralmente todas as etapas de atendimento da Instituição, com o objetivo de verificar-se a forma como este se dava, tanto do ponto de vista metodológico quanto técnico, a fim de avaliar-se sua adequação à proposição de novas políticas públicas, atendendo a edital da Fapesp e Prosare.
} 
grupo masculino, a possibilidade de conversarem sobre temas pessoais, se os temas abordados e as discussões realizadas haviam tido algum efeito em suas vidas pessoais ou suas concepções de vida, e sobre a forma como foram coordenados tais grupos. Por este motivo, optamos em apresentar apenas os extratos das falas que estejam diretamente relacionadas à nossa investigação. Essas falas estarão na Conclusão.

\subsection{METODOLOGIA}

A metodologia de análise que usamos para discutir os relatos aqui descritos baseia-se numa abordagem psicanalítica, associando-se a compreensão metapsicológica às formulações do construcionismo social. O método psicanalítico propõe a construção de modelos de funcionamento mental baseados em inferências relativas ao estudo das manifestações grupais ou individuais, estando, em nosso trabalho, voltado à análise do discurso dos participantes do grupo.

Procuraremos analisar e identificar, valendo-nos do material descrito e de maneira análoga a um estudo clínico, as manifestações relativas à violência de gênero e suas formas de expressão. Ao caracterizar como estudo clínico, não pretendemos fazer a análise psicológica de cada indivíduo, como tampouco categorizá-los de forma genérica e estereotipada. O que garantiria na abordagem psicanalítica uma ética da alteridade, do respeito pelo aspecto desconhecido do outro que nos impeça de cairmos numa 'redução' deste outro a um simples modelo representacional é o que questiona Nelson da Silva Jr., ao propor "uma possibilidade de solução do impasse ético entre a psicanálise como ciência do inumano e como saber do humano no homem” (1999, p.131). Diz o autor a respeito das condições a serem preenchidas por aquele que se propõe a pesquisar em ciências humanas que: “a humildade de manter-se diante do outro como diante de um enigma é uma condição de possibilidade na reflexão sobre o humano em harmonia com uma postura ética” (idem, ibidem). Silva Junior (1999) descreve 
processo de desligamento que os estudos da psicopatologia foram adquirindo em relação à psiquiatria tradicional, de forma a eliminar a oposição existente entre normal e patológico. O estudo da psicopatologia irá aproximar essas duas categorias, e Freud lhes atribuirá diferenças meramente de intensidade e não mais, de qualidade. Vai-se eliminando a oposição entre estas categorias. Mas Freud irá avançar para além do estudo da psicopatologia ao propor o método psicanalítico para compreender a cultura, afastando-se de uma busca pela normalidade, conceito do campo da psicopatologia. “A ‘normalidade’ é uma grande incógnita no método psicanalítico de investigação” (1999, p.135), diz o autor. A pesquisa psicanalítica portanto, em suas palavras, "supõe um profundo desconhecimento da cultura”, propondo-se a tratar a “alteridade como enigma”. Tarefa difícil, afirma o autor, porém “essencial à noção de respeito, não somente em psicanálise, mas em ciências humanas em geral” (idem, ibidem).

É, por conseguinte neste referencial que nos apoiamos, a fim de encontrar subsídios que nos auxiliem a escutar as falas dos homens do grupo de forma a podermos construir modelos de funcionamento mental, ainda que provisórios, visando à compreensão de como e por que determinados valores culturais são incorporados, passando a exercer o poder de determinar formas de comportamento. Assim, as falas não têm como objetivo a realização de um estudo particular dos participantes dos grupos, mas, antes, de servirem como ilustração de uma forma de funcionamento, em um determinado grupo, em seu específico contexto social e cultural. Cito Carvalho (2003), ao justificar a pertinência do uso de uma metodologia não quantitativa, apoiada em material subjetivo dos pesquisados: “as informações obtidas funcionaram não só como ilustrações de nossas hipóteses, mas, sobretudo, como possíveis norteadoras dos pontos teóricos mais essenciais que deveríamos abordar” (idem, p.32).

A maneira como desenvolvemos nossa metodologia de trabalho resultou do trabalho em si, ou seja, tanto a idéia de escrevermos a dissertação quanto a forma que aqui utilizamos para nossas análises não foram pensadas a priori. Durante alguns anos, vimos realizando a 
atividade de coordenação de grupos de reflexão masculinos, cuja finalidade já descrevemos anteriormente. Assim, estes grupos faziam parte de um processo maior dentro do serviço de atendimento da PMFC. Ao longo dos anos, fomos observando certas repetições nos relacionamentos, nas expectativas voltadas a estes e no tipo de respostas dadas, como decorrência da frustração destas expectativas, o que nos despertou curiosidades e questionamentos. Ainda que tenhamos observado nas falas destes homens uma repetição de padrões ligados aos valores hegemônicos, é, contudo notável que, embora fazendo parte de um mesmo grupo social, regido por normas e valores muito semelhantes, encontremos variações no que diz respeito ao tipo de resposta mais ou menos violenta, ou à maior ou menor possibilidade de abstração ou flexibilização de tais padrões da cultura. O que justifica que alguns homens reajam de forma violenta contra sua companheira, evidenciando um comportamento totalmente aderido aos padrões da cultura hegemônica, e outros se mostrem mais abertos a questionarem tais valores? Essa observação por si só justifica que nos questionemos quanto à exclusividade dada aos valores transmitidos pela cultura na construção da subjetividade dos indivíduos. Se a cultura exerce, sem dúvida nenhuma, um papel determinante, não obstante, acreditamos ser imprescindível olharmos para além desta a fim de podermos levantar hipóteses sobre como e por que, a partir da compreensão das dinâmicas psíquicas, estes valores podem adquirir estatuto de verdade normatizadora de padrões de comportamento. Embora fora do escopo deste trabalho, fica ainda a questão a ser pesquisada sobre o que leva às diferenças relativas à adesão a estes padrões, que, por sua vez, levam a um maior ou menor grau de violência como resposta. É importante ressaltar que, apesar do padrão de respostas violentas ser mais prevalente nas classes populares, como veremos em outras pesquisas citadas nesta dissertação, a condição socioeconômica não pode ser vista como única determinante deste tipo de resposta. Procuramos, ao longo do trabalho, questionar os modos pelos quais os indivíduos se identificam com os elementos da cultura e 
as formas de expressão destes nos relacionamentos entre homens e mulheres, em suas relações de vinculação.

Para tanto, reproduzimos o mais fielmente possível quatro encontros de grupos, sobre os quais fomos tecendo comentários, entremeados às falas dos sujeitos, procurando identificar e oferecer subsídios, baseados nas teorias construcionista e psicanalítica, que nos auxiliem na compreensão das relações violentas de gênero.

Do campo construcionista, adotamos autores que discutem o caráter naturalizado na cultura do padrão de masculinidade hegemônica nas relações entre os gêneros, que dizem respeito a formas de reprodução e perpetuação nas relações de poder.

Do ponto de vista psicanalítico, a questão da agressividade e da violência será discutida, articulando-se conceitos tais como narcisismo, ideal de ego e superego, no que estes têm de reprodutores dos valores culturais. Teceremos ainda formulações sobre o processo de identificação, uma vez que este se relaciona com a adesão a valores veiculados no interior das diferentes formas de agrupamento social, como também acerca do conceito de acting-out como forma de expressão que substitui o pensamento por uma ação, assim como formulado por Freud (1911) e ampliado por Bion (1991). Finalmente procuraremos discutir esses conceitos em sua relação com as formulações sobre desamparo e violência, vistos em Freud e amplamente discutidos no trabalho de Isabel Kahn Marin (2002).

É bem verdade que Bourdieu (1998) nos adverte sobre a dificuldade de tentarmos pensar a dominação masculina "sob o risco de recorrermos ou nos submetermos a modos de pensamento que são, eles próprios, produtos de milênios de dominação masculina” (IDEM, p13).

Arriscaremos, ainda assim, a nos empreender no estudo do que ele caracterizou, citando os trabalhos de Erving Goffman (op.cit, p.12), “a elevar à dignidade de objetos científicos os ‘pedaços e bocados' da vida social que estavam diante dos olhos de todos”. 
Não temos a pretensão de esgotar a questão, nem tampouco somos os únicos a estudar a questão da violência de gênero. Simplesmente pretendemos, como psicanalista trabalhando no campo da psicologia social, compartilhar nossas observações, fruto de nossa experiência, a fim de trazer subsídios que possam contribuir para a transformação destes padrões de relacionamento.

\subsection{ASPECTOS ÉTICOS}

Os aspectos éticos desta pesquisa estarão plenamente assegurados uma vez que, em relação aos participantes dos grupos, será garantido total sigilo quanto à sua identificação, já que suas falas serão usadas como material de apoio aos textos teóricos, não implicando qualquer tipo de prejuízo pessoal, nem tampouco os expondo ao risco de identificação. Os atores são aqui citados como representantes de um tipo de relação que pretendemos estudar nesta pesquisa, usando a citação de exemplos como forma de ilustrar e contribuir para a compreensão dos estudos da violência no campo das relações de gênero.

Os exemplos serão tratados de forma semelhante ao tratamento de um material clínico, visando a contribuir com um fenômeno de amplas e graves repercussões no âmbito das relações interpessoais, familiares e sociais. Ainda assim, foram preenchidos os termos de consentimento informado pelos participantes das sessões relatadas e do grupo focal.

Por fim, uma vez que o uso de nomes próprios poderia causar algum desconforto e na falta de recurso que julgássemos melhor para denominá-los, garantindo ao mesmo tempo, o máximo possível, o anonimato dos autores das falas, optamos por atribuir, aos atores que aqui falam, letras do alfabeto.

\subsection{QUATRO SESSÕES DOS GRUPOS DE REFLEXÃO MASCULINA}

3.5.1 Grupo de 02.04.2004 
7 Usuários Presentes: A,B,C,D,E,F,G

Presentes também a coordenadora, o assistente e as duas pesquisadoras.

O grupo começa com a retomada da explicação da metodologia empregada na Casa.

Explicamos que irão procurar fazer um acordo (no processo de mediação), mas que, para isso, devem ter em mente que, se o acordo for muito desigual para qualquer das partes, nenhuma das duas irá concordar. É comum enfatizarmos a necessidade de considerarem que o outro (a companheira, ex-companheira etc.) também deve ser atendido em suas necessidades, para que seja possível a realização de um acordo em moldes diferentes do jurídico tradicional no qual eles não terão interferência na determinação do juiz.

A: "e dentro da coerência também".

Concordo com ele e prossigo: “esse acordo vai ser homologado, vai ser assinado pelo juiz”.

B: “eu vou sair, vou deixar a casa (onde mora atualmente), mas se for para eles (sua família) venderem e sair para outro lugar, eu não aceito”.

Coordenadora: "Isso também é um assunto que você pode conversar e combinar na mediação”.

B continuou dizendo: "se for para vender, então eu quero minha metade".

Tentando abordar a questão a fim de propor outros pontos, digo: "então, você coloca tua posição, mas a gente sempre tem que considerar que o outro pode ter idéias diferentes das nossas”.

Depois passamos a trabalhar com a dinâmica que havia sido preparada, dando continuidade a um tema que havia sido discutido na semana anterior.

Coordenadora: "na semana passada eu perguntei qual é a coisa que uma mulher fala que mais ofende o homem”. 
As respostas vão sendo anotadas em um quadro. A lista consiste nos seguintes itens: usar segredos, agressão, abandono e maus tratos, acusações de crápula, chamar de corno e veado, traição.

Essa é uma atividade que visa a despertar e discutir, com base na fala dos homens, suas expectativas em relação a valores e lugares desejados dentro da constelação familiar. Nesta lista, denominações como corno, veado e traição se chocam com as expectativas de masculinidade hegemônica e os desqualificam quanto a um ideal de masculinidade, não só em relação a eles mesmos mas também perante outros homens.

Visa, ainda, a discutir formas de comunicação sentidas como agressivas, o porquê e como elas se dão e as repercussões dessas falas no relacionamento conjugal.

Connel (1995) nos fornece subsídios para a compreensão deste sentimento ao dizer que “a opressão coloca as masculinidades homossexuais na parte mais baixa de uma hierarquia de gênero entre os homens (...) Portanto, do ponto de vista da masculinidade hegemônica, a homossexualidade se assemelha facilmente à feminilidade” (idem, p.78).

Vivências de segredo, agressão e abandono denotam a perda de um lugar que desejam manter: o de chefe da casa, de autoridade. Pensando nos ideais culturais de masculinidade, a manutenção desta hegemonia garantiria aos homens a permanência num lugar hierarquicamente privilegiado. Pela ótica psicanalítica, o sofrimento advindo deste afastamento afetivo (real ou imaginado), por parte da companheira, sugere a revivência de uma experiência arcaica na vida da criança: aquela que remete a um lugar de exclusão e de castração. A compreensão de dinâmicas psíquicas, associadas aos códigos definidores de masculinidade tradicionais e vigentes nestes homens (verificados por meio de seu discurso), revela-se pela recusa em ocuparem esses lugares significados 
como não-masculinos, castrados, desvalorizados. Assim, verificamos como muitas vezes a tentativa de reverter esta situação se dá pelas falas acusatórias destes homens, de teor denegridor da moral feminina, com o propósito defensivo de recuperação de um equilíbrio narcísico.

Quando surgiu o tema da traição, tentei explorar a questão tratando das diferentes interpretações dadas à traição quando praticada por um homem ou por uma mulher. Para os usuários, o homem traído é visto como corno e alvo de chacotas em seu círculo de pares; já a mulher traída é vista como trouxa e coitada. Por tais motivos, diziam que a traição da mulher é absolutamente imperdoável.

C: “abandono é algo extremamente doído”.

A zombou do colega e disse: "é para quem gosta”.

A zombaria o distância de uma identificação com o companheiro que sofre e evita a aproximação com o tema da perda e da dor que o traz à Instituição. Ele usa de um recurso de tipo ‘machão’, que o protege da fragilidade.

Coordenadora: “você sente que tem muita coisa que deu para ela e ela não valorizou?”.

B: “não adianta nada, você dá o carinho, o afeto e ela não aceita”.

A: “mas aí, Susana, cada caso é um caso. De repente ele gosta da esposa dele, é uma perda. Tem coisas que você confessa, é calúnia. De repente ela falou assim: eu apanhei de você 20 anos diante de um amigo que você conhece. Isso é uma ofensa grande. É covarde Susana, acusar você de crápula. Tive uma história de agressão e chegou na delegacia e ela disse que eu não ajudo lá há cinco anos. De repente ela não quer admitir que teve uma traição. Ela arrumou outra pessoa e quer viver com ela e tirar eu de casa. Eu já falei para a mãe dela e (ela) disse que se ela não sabia é porque não aconteceu”.

G: "essa coisa de que a mãe não sabe, não é bem assim, depende do histórico da relação dela com os pais”. 
A em tom lamurioso: "é horrível isso. Ela chegar para um amigo do casal e falar uma coisa dessas de você”.

Coordenadora: “dessa vez que vocês foram à delegacia, o que aconteceu?”.

A: "eu não agredi ela. Eu agredi minha filha e meu filho. Minha filha deu um tapa na minha cara e eu revidei. Eu me defendi e lá na delegacia da mulher eu fui discriminado pela funcionária que não deixou eu sentar perto dela”.

F: “se ela chama de corno, ela está se prejudicando".

B: “ela está revelando o que ela está fazendo, então ela é uma puta. Eu deixo para lá”.

Aqui verificamos novamente uma mudança no curso da conversa já que, se antes falavam da dor, do abandono e da traição, isso se transforma em acusação da moral da mulher, numa atitude de espelhamento, pois se o ideal masculino exige a eliminação do “corno”, o feminino exige a garantia da mulher 'pura' e não, 'puta'. Assim, não só temos o exemplo de como a dor se transforma em agressão, como vemos a complementaridade em espelho da comunicação agressiva, na qual os ingredientes ofensivos são justamente aqueles ditados pela cultura hegemônica.

Coordenadora: "se ela fala quer dizer que é verdade ou será que esse tipo de acusação pode ser usado pra outra finalidade?”.

Aqui a pergunta objetiva trabalhar a questão do compartilhamento de alguns valores e que, portanto, as mulheres, ao usarem esse tipo de acusação, invertem a balança dos poderes, atingindo os homens em seu 'ponto fraco'. A fala, mais do que revelar um fato, tem como intuito ofender a necessidade de manutenção de um lugar de masculinidade onde ser 'corno’ não é tolerável.

E sorriu e disse: “às vezes não é”.

B e F concordando entre si dizem que às vezes é apenas para ofender. 
G partilha da mesma opinião: “eu vejo casais que ficam meio se alfinetando”.

Há uma mudança no discurso baseada na possibilidade que se abre de questionar suas afirmações. Esse é um dado novo.

E: "traição, se acontecer comigo, não tem volta".

A: “quando você gosta da pessoa é horrível”.

C: "o chato é todo mundo ficar sabendo, você é direito".

O olhar do outro é definidor da identidade daquele que é visto. A impossibilidade de manter-se no que consideram o ideal de masculinidade é dado a partir do olhar do outro, sugerindo a indisponibilidade de outros signos definidores nos quais possam se ancorar. A questão do olhar do outro como fundante na construção da identidade e subjetividades do sujeito é tema bastante conhecido na teoria psicanalítica. Em capítulo de $O$ Brincar e a Realidade, Winnicott (1971), afirmando ter-se inspirado em Lacan, diz: “No desenvolvimento emocional individual, o precursor do espelho é o rosto da mãe" (idem, p.153) ${ }^{27}$. Essa afirmação contém a idéia de que o indivíduo constrói uma noção de si mesmo através do que vê nos olhos de sua mãe ao olhá-lo. O olhar da mãe seria como um espelho, refletindo para o sujeito sua identidade, ou, ainda, ele (o sujeito) é definido por aquilo que encontra no olhar daquele que o olha. Esse modelo do olhar do outro como espelho definidor da identidade é o que depreendemos da fala de C.

Coordenadora: “então pior do que a traição é os outros ficarem sabendo".

E fez um gesto negativo com a cabeça e disse: “para mim só a traição”.

C retomando seu ponto de vista: "a gente trabalha no mercado, a gente sabe cada uma. Os outros ficam sabendo e te aluga”.

\footnotetext{
${ }^{27}$ Em recente conversa com Nelson da Silva Jr., este relatou uma Síndrome que lhe foi descrita por um médico, denominada Síndrome do Vestiário. Desenvolveu-se como técnica para tratar desta síndrome, caracterizada pela inibição em ter o pênis visto por outros homens nos vestiários, uma cirurgia de espessamento do mesmo, cujo único intuito é o de evitar um sentimento de constrangimento quando visto por outros homens nos vestiários masculinos, já que esta cirurgia, segundo o médico, não tem qualquer outro efeito, seja no tamanho que o pênis atinge ao estar ereto, seja no desempenho ou no prazer sexual.
} 
Coordenadora: “e quando o homem trai a mulher?”.

A: “normal, de repente acabou”.

Coordenadora: “e uma mulher quando é traída,como é que ela é vista?”

E: "como chifruda".

B: “não vão falar que é corna, apenas que está sendo traída”.

Coordenadora: "chamar de corno, para os homens, tem o sentido de ridicularizar? E a mulher não fica humilhada?”.

C: "é a mesma coisa".

Coordenadora: “como assim, o que vão dizer dela?”

E: “que é trouxa”.

B: “a mulher é mais ameno porque as amigas ficam sabendo e o homem não fica”.

A em tom de concordância: "a coisa fica confusa. O homem quando trai não fica tão discriminado".

Neste momento, $\mathbf{C}$, mais agitado, se levanta para dizer que sua ex-esposa andava de cabeça baixa pelo bairro porque o traiu.

B então tentou sintetizar a idéia: “o cara é macho e a mulher é puta, mas trai porque ela não foi bem tratada às vezes”.

C “eu acho que é a cabeça da pessoa. Tem uma vizinha que era bem tratada e começou a conhecer colegas...”.

Neste pequeno extrato de discussão, podemos identificar uma certa unanimidade em relação à atribuição de sentidos que é dada para a traição masculina e feminina. Nota-se que o sentido dado ao homem traído é denegridor de sua moral masculina, enquanto a mulher traída é vitimizada, mas não ridicularizada. É notável também a dificuldade em buscar no interior do relacionamento fatores que determinem a traição 
feminina, o que os leva a atribuir “às más companhias ou às colegas” a motivação para tal ato.

Essa é uma formulação bastante habitual, a de buscar atribuir ou encontrar fora da relação do casal a justificativa para a traição. Segundo esta teoria, a mulher que sai de casa fica arriscada a ver outras coisas e "virar a cabeça". $O$ julgamento é imperioso: “a mulher é puta”. ${ }^{28}$ Não há um questionamento quanto a algo que possa ser do âmbito da própria relação, que implique o homem como sujeito ativo. $O$ mal está fora e precisa ser eliminado para não contaminar a família. Pensamos que este tipo de (in) compreensão tem como finalidade evitar a desestabilização desses homens em relação ao que entendem que seja sua base de suporte identitário, que são suas crenças, seus paradigmas. É uma idéia de estrutura paranóide, uma vez que está calcada num mecanismo de projeção ou expulsão do mal. Vemos este tipo de funcionamento também como aquele no qual se sustentam as crenças e os comportamentos preconceituosos, de intolerância e perseguição a homossexuais, prostitutas etc, em que o mal é aquele que, pondo em cheque os valores de determinado sujeito, desperta neste o desejo de eliminar aquele, livrando-se do risco de se "ver contaminado"

Visando questionar a idéia de que a vizinha tivesse sido influenciada e sugerir que há outras possibilidades para entendermos a traição, pergunto: "será que a gente sabe o que acontece entre as pessoas?”.

B respondeu, dizendo: “a gente mantém as aparências”.

\footnotetext{
${ }^{28} \mathrm{Em}$ um dos grupos, deu-se um fato interessante, quando um dos participantes, que hoje é casado em segundas núpcias, conta que conheceu esta mulher quando os dois eram casados com outros companheiros, tendo ambos se apaixonado um pelo outro e, assim, se casado após deixarem seus antigos pares. Ele afirmava que esta sua mulher havia traído o marido, pois eles haviam se apaixonado e que hoje viviam muito bem e se respeitavam. Fez questão de afirmar isso questionando a definição de que mulher quando trai é porque não tem valor.

${ }^{29}$ Apoiados na teoria psicanalítica sobre a paranóia, Adorno e Horkheimer fazem interessante estudo sobre as razões que determinariam a construção das personalidades fascistas. A descrição das características de personalidade que coloca o mal de forma exterior ao sujeito, e o leva à perseguição do diferente, evidencia tanto uma rigidez de códigos de valores, como um temor da ameaça do 'contágio’. Sugiro a leitura de: $L a$ Personalidad Autoritária (1945).
} 
E: "eu acho que a traição é por conta da relação sexual em casa, se o cara é ruim, leva mesmo. Eu tinha três namoradas e um amigo ficava vinte dias sem procurar a mulher. Se a mulher procurar o homem e ele não quiser, ela não aceita”.

Aqui vemos a tentativa de encontrar uma explicação, diferente da anterior, aproximando a questão para um dentro em lugar de um fora. Contudo, as hipóteses continuam no terreno das regras quanto ao que deve ser um homem dentro deste modelo hegemônico. Assim, caberia ao homem ter de apresentar prontidão sexual, atendendo a um ideal numérico que se mostra não menos persecutório que o anterior, pois o risco do não- preenchimento deste ideal justificaria à mulher busca-lo num outro homem, substituindo o que o primeiro não se mostrou suficientemente competente para lhe prover.

A: “As mulheres podem ficar sem transar por muito tempo, mas os homens não”.

E: "Se a mulher não quer, o homem aceita. Mas se o homem não quer, a mulher não aceita". B diz: “A mulher pode pensar que, se ele não procura ela há muito tempo, já vai pensar que é porque ele tem outra”.

E sempre rindo, diz: “Tem que ser 2 vezes por semana. Para mulher pode ser uma vez por mês".

Coordenadora: "A mulher pode mostrar a sua sexualidade? Um homem disse outro dia em um grupo que o homem convida a mulher para sair porque quer sexo, mas ela não pode aceitar, porque se ela quiser, fica mal falada”, com o que todos concordaram.

B: "As difíceis é que valem a pena".

Dirigindo-me a $\mathbf{D}$, que ainda não havia falado: “D, o que você acha?”.

E riu e disse: “esse aí tem trauma de mulher”.

Coordenadora: “é assim que homem provoca homem?”.

D sorriu timidamente e disse: “cada um tem sua reação”. 
Coordenadora: "é uma provocação? Tipo, 'prova aí que você é homem’. E como é que é? O homem quando é provocado precisa provar que é homem?”.

A olhou para a técnica e disse: “não sei, dá uma porrada no homem”.

G riu muito e disse: "como se isso fosse a coisa mais simples".

C: "os homens costumam responder a uma provocação de outro homem dizendo que vão comer a mãe ou a irmã do outro”.

A comentou: "isso aí dá uma briga feia, você ofendeu a moral do cara e ele ofendeu sua mãe.

Aí você explode, não dá tempo de você pensar”.

Coordenadora: "será então que homens e mulheres não podem desejar a mesma coisa?”.

A concorda: "é uma discriminação".

Coordenadora:“então a mulher que gosta do que o homem gosta ela não presta?”

Todos riram dando-se conta da incongruência e G disse, rindo: “Assim você está encurralando...”.

Coordenadora: “por quê?”,

G: “ambos querendo, seria perfeito (e fez um gesto com as mãos representando um ‘encaixe’), os dois querem o mesmo”.

A: “As coisas mudaram. Antes as mulheres casavam virgens", e eu lhe pergunto o que achava disso.

A, F e B: "Não é bom. É melhor conhecer antes."

E: “O que interessa é o caráter da mulher.”.

À medida que a conversa avança e certos paradigmas são discutidos, há um encaminhamento em direção a uma conciliação de interesses, indicando uma transformação por meio do questionamento de um padrão rígido de comportamento sexual atribuído a homens e mulheres, que vemos na frase que conclui este trecho: “o que interessa é o caráter da mulher”. 
Aproveito o tema para perguntar: "e se, por exemplo, uma mulher se insinuar para o cara, ele pode recusar?”.

A: "pode, lógico".

Os demais não falaram nada; alguns riam e conversavam entre si em voz baixa, evidentemente discordando da resposta dada.

Coordenadora: "eu estou pensando aqui que a situação dos homens deve ficar muito difícil se ele não pode dizer não”.

B sorriu e disse em tom baixo, como se estivesse fazendo uma confidência: "a própria mulher pode desconfiar que ele tem outra. Os outros vão falar que é um broxinha."

Coordenadora: "por que vocês acham que tem essas diferenças? É uma preocupação ter que provar que é homem?”.

B riu e falou para os que estavam próximos: “corno é pior do que veado.”

Nesta seqüência de conversa, vemos a questão da sexualidade masculina como algo que, ao contrário de lhes garantir poder (como tendem a acreditar), lhes aprisiona no que Corsi (1995) descreve como sendo a base sobre a qual se constrói a identidade masculina: o hiperdesenvolvimento do eu exterior (fazer, conseguir, agir) e a repressão da esfera emocional.

Em seguida, proponho uma dinâmica que consistia em um treino de mediação. Um faria o papel do marido e outro, da esposa.

F propôs que G fizesse papel de mulher “porque ele usava vários brincos”. 
É comum que se estabeleça um incômodo ou até mesmo uma recusa em representar o papel feminino, sob o risco de que isso os aproxime de uma identidade feminina, afastando-os do que denominei de sua identidade desejável. A maneira encontrada para 'se livrar' ou proteger-se do lugar indesejado, dá-se, neste trecho, por meio da identificação, no outro, de atributos rigidamente associados a códigos femininos.

Vemos também nesta passagem que, num mesmo grupo, encontramos expressões de diferentes masculinidades e ainda a maneira como estas se chocam. $O$ motivo de pedir a $F$ que fizesse o papel de mulher foi o de que pudesse experimentar-se em outro lugar, diferente daquele que se vê obrigado a exercer. Assim, com o meu pedido, fica autorizado e pode sentir-se menos ameaçado de ser ridicularizado pelos colegas.

G incomoda-se com o comentário do outro, mas tenta disfarçar levando na esportiva. Por fim, F aceita fazer o papel solicitado.

Os outros devem fazer o papel de mediadores, fazendo perguntas, procurando descobrir quais eram as versões de cada parte sobre o conflito entre eles: "vocês já viram que para homens e mulheres às vezes as coisas são diferentes. O mediador não vai julgar. $O$ casal quer se separar, mas estão vivendo na mesma casa por uma questão financeira. Cada um já tem interesse em outras pessoas e isso tem gerado muita briga dentro de casa”. (Tratava-se do caso de um deles.)

Eles entenderam a proposta e $\mathbf{F}$ assumiu o papel de esposa e $\mathbf{D}$ foi escolhido pela técnica para ser o mediador.

A entrevista começou com $\mathbf{F}$ dizendo: “meu marido e eu só brigamos, eu já tenho outro namorado".

D: "têm filhos?"

F concorda com a cabeça e o mediador indaga: “já é grande, já?”. 
A interrompeu e rindo, disse: "eu acho que ele está conquistando a esposa, não está fazendo pergunta”.

Este comentário é sugestivo de que a conversa de cunho mais íntimo pode ter causado constrangimento, suscitando um comentário que visava aliviar este incômodo.

Propus então que $\mathbf{D}$ tentasse explorar um pouco mais a relação do casal: “lembra que tem história de violência”.

F interrompeu-a para dizer: “mas eu digo que não tem”. E riu muito.

Mediador: “o que você está chamando de violência?”.

F respondeu: "traição com a vizinha, começou aí”.

Trocam-se o mediador e o casal por outros participantes para que eles possam experimentar esses papéis.

A: "eu traí ela e ela não quer mais ficar comigo, acabou”.

Coordenadora: “lembrem-se que tem um namorado e isso está dando briga”.

A ficando mais exaltado diz: "ela quer tirar minha casa e não vou sair, se acha que eu vou dar a casa para vagabundo”.

Mediador: “por quê? Você gostaria?”.

A: "eu jamais vou deixar minha casa com os filhos e ele lá dentro com ela”.

Mediador: “e se eles quiserem ficar com a mãe na própria casa?”.

Coordenadora:: "por que você está dando idéias para ele? a idéia é que eles possam chegar a uma solução entre eles”.

Assistente: "e ninguém perguntou o lado dela".

A:: "quem escolheu foi ela, ela teria que sair”. 
Coordenadora: "o conflito parece que é a casa e nenhum dos dois quer sair de lá. E tem os filhos e um sentimento de humilhação. Será que às vezes a briga pela casa e pela pensão não tem a ver com esse sentimento de humilhação?”.

Mediador saindo do papel, diz: “o meu filho não vai deixar ela pôr outro homem lá”. Coordenadora: "e se esse marido resolver levar outra mulher para aquela casa e a esposa concordar em sair, aí pode?”.

G: "para o marido não ia pegar mal”.

A: nesse momento passa a falar abertamente sobre o que o traz à Instituição (havia pedido que seu caso não fosse aberto aos outros pois se sentia muito envergonhado): “no meu caso, a casa é dos meus pais e meus irmãos não aceitam ela levar alguém”.

B: "ele pode se dispor a pagar um aluguel para ela fora".

A: "eu posso expor o meu caso e eles poderão analisar. Nós fomos casados durante vinte anos. Ela disse e eu já sabia que ela tinha outra pessoa. Foram três vezes de traições, três vezes já é demais. Não tem nada para me desabonar. Eu conversei com as crianças e elas disseram que não poderiam mandar a mãe embora”.

“Eu nunca cheguei, jamais eu disse: oh, sua vagabunda, levanta daí e vai fazer comida. Ela resolveu sair de casa e eu propus que ela pensasse o que queria”.

Continua seu relato contando que depois disso decidiram ainda tentar viver juntos. Ele lhe deu um presente do Dia das Mães que era uma cacharel (sic) de lã e em tom magoado disse: "ela disse que era uma porcaria”.

Explica que havia feito isso para testá-la, pois tinha uma jaqueta de couro no carro, presente de maior valor, e queria ver sua reação diante da cacharel. Conta que ela então jogou a blusa em sua cara, insinuando que era um presente insignificante.

G: "a cacharel foi a gota d'água para ela descarregar vinte anos de frustração na sua cabeça." 
A continuou dizendo que o filho tinha ficado muito chateado com a atitude da mãe, especialmente porque ela aceitou e gostou muito da jaqueta de couro.

Em seguida propus que $\mathbf{G}$ fizesse o papel de mediador, mas ele recusa alegando que sua cabeça já estava latejando de tanto pensar.

A continua sua narrativa dizendo em tom indignado que perdera $6 \mathrm{~kg}$, havia sofrido muito. “Não tinha com quem conversar, fui à Igreja rezar, para me acalmar. Pensei em matar ela. Depois comecei a me relacionar com outras mulheres”. Em tom de indignação diz: "ela namora um menino de 20 anos e tem 40 anos”.

Coordenadora: “uma mulher mais velha não pode namorar alguém mais novo?”, ao que todos responderam ser “estranho”.

E: "eu tenho duas namoradas de 27 e 33 anos, e tenho 48 anos. Sou machista mesmo: elas não podem ter outro".

Um dos integrantes ri muito e eu lhe pergunto o motivo da risada. Quem responde é outro integrante, dizendo : “é o amante. Ela está provocando ele” (referindo-se à mulher de A).

A: "você acha que ela tem o direito de fazer isso?".

F responde que não e acrescenta: “ele fica humilhado”.

A explica que sua mulher havia trazido a roupa do namorado para lavar em sua casa, escondido, e pendurado no varal. Conta que ficou nervoso e ameaçou pôr fogo em tudo se ela não tirasse a roupa de lá. Dizia que seus irmãos queriam tirar todos de lá porque não agüentavam mais as constantes brigas. Disse também que a esposa havia chamado a polícia quando ele bateu no filho, pois acusava este de não ver que sua mãe estava colocando roupas de outro homem no varal da família. 
Continua dizendo: “Eu também estou saindo com outras pessoas, mas ela sai e passa o fimde-semana fora. É pior. Eu saio, mas volto todos os dias. Um dia eu percebi que ela estava levando roupa dele (atual companheiro) para lavar em casa. Eu chamei minha filha, que também disse que isso não estava certo.”

Coordenadora: “será que o que te deixa bravo é que expondo as roupas no varal ela traz a presença do namorado para a casa de vocês?”

A: “não porque já não nos gostamos mais”.

Aqui, a questão do gostar, do envolvimento afetivo não é a questão principal, mas a humilhação sentida, materializada pelas roupas no varal, que evidenciam a presença de outro homem em seu lugar. A questão discutida no início desta sessão, sobre o sentimento de vergonha de ser exposto como 'corno' ao olhar alheio se expressa na situação do varal.

A: Diz ainda que estava preocupado em garantir a segurança dos filhos, deixando a casa para eles, sem sair de casa, pois, do contrário, iria viabilizar que sua esposa vivesse com outro homem naquele espaço.

Neste momento G aponta: “a preocupação não é com os filhos, pois se eles estão sendo chamados o tempo todo para resolver tudo quando é picuinha, brigas”.

E propôs ainda que A saísse da casa deles, o que ele recusou, dizendo “A casa foi construída pelo meu pai, imigrante. Ela escolheu, ela que saia.”

B propôs que ele a ajude, pagando um aluguel, ao que ele disse "De jeito nenhum! Ela escolheu o outro. Ela que saia”.

Coordenadora: “não é fácil desfazer um casamento de vinte anos, né?”. 
A responde: "ela que escolheu essa situação. Ela tem que sair. Ela ganhava mais do que eu”. E depois perguntou aos outros: “e aí vocês aceitam ela levar a roupa do cara?”. Vários disseram que não.

Coordenadora: fazendo referência a comentário de $\mathbf{A}$ sobre o que havia dito que às vezes sentia que iria perder a cabeça, diz: "quando você achar que vai perder a cabeça, venha aqui”. Encerrou-se o grupo naquela manhã.

\subsubsection{GRUPO DE 16/04/2004}

Usuários presentes: A, B, C, D, E, H, I, J, P.

Em razão da presença de novos participantes, inicio o grupo me apresentando como psicóloga da Casa, apresentando também o estagiário e as pesquisadoras. Explico a finalidade dos grupos, a metodologia e esclareço dúvidas.

Em seguida proponho uma atividade usada quando há pessoas iniciando os grupos: uma espécie de 'treino de conversa'. Proponho que se juntem em pares, durante alguns minutos, e cada participante irá 'entrevistar’ o colega, que então será apresentado ao grupo pelo entrevistador e não, por si mesmo.

Algo observado ao longo dos anos de atendimento nos grupos masculinos é a dificuldade que muitos deles têm em relatar suas questões pessoais a outros homens. Assim, este aquecimento visa a proporcionar uma situação de aproximação por meio da conversa, propondo um modelo de relacionamento com o qual estão pouco familiarizados (numa primeira desconstrução paradigmática contida na idéia muitas vezes expressa por participantes dos grupos de que homens não trocam confidências com outros homens). É também uma maneira de serem colocados no papel de ouvintes, alterando-se um modelo no qual têm a expectativa de serem ouvidos por uma autoridade que se encarregará de resolver seus casos de forma assistencialista. Deste modo, esta atividade propicia o início de dois 
processos significativos: rompe com modelos e expectativas conhecidos dentro da proposta institucional de desconstruir narrativas, bem como inicia estes homens, que se encontram em conflito com suas companheiras, numa atividade de experimentar-se como ouvinte de outro, reproduzindo e refletindo sobre estas outras histórias, que podem conter diferentes pontos de vista.

Coordenadora: “Bom, é assim, eu tenho que saber o nome de todo mundo, a história de cada um. Pensem que vocês são entrevistadores - perguntem, por exemplo, o que fez o colega procurar a Instituição, o que esperam..”

I (que já fizera essa dinâmica em um outro grupo) diz: "Mas vocês têm que ser objetivos, responder ao que a pessoa está perguntando.”

Coordenadora: “Como assim?”

I: "Porque já vão se fazer de vítimas..."

Coordenadora: “Bom, essa é uma das regras pra se fazer mediação: não dá pra ir deduzindo coisas porque a gente não sabe o que está passando na cabeça do outro. Então tem que perguntar pra saber.”

Eles fizeram a dinâmica proposta, conversando entre si animadamente durante 15 minutos.

O primeiro a fazer a apresentação foi $\mathbf{D}$, que apresentou $\mathbf{C}$ : “A história dele é a seguinte: ele tem uma filha de 10 anos, ele pagava um salário mínimo de pensão. De um tempo para cá, não pode dar mais esse valor porque tá desempregado. Vinha dando R\$146,00, mas ela (sua ex-mulher) não aceitou, acostumou-se com o salário mínimo. Ele veio aqui atrás dos direitos dele”. 
Pergunto se o entrevistado tinha outros filhos e $\mathbf{D}$ responde que não havia lhe perguntado isso. É freqüente que o entrevistado refira somente os filhos em relação aos quais haja alguma ação jurídica.

Coordenadora: “Que outras coisas ele poderia perguntar?”.

C, sem esperar resposta, começa a contar sua própria história: “eu tenho quatro filhos. Há dez anos foi legalizada a pensão. Eu trabalho por conta, sou pedreiro, e o serviço caiu bastante. Ela foi no juiz achando que eu não pago porque eu não quero. As vizinhas ajudam: vamos pôr ele no pau”.

Conta que havia se casado uma vez anteriormente, tendo uma filha com esta primeira companheira, que, por sua vez, tem outros quatro filhos "com outros pais que não pagam nada”. Disse que depois se casou de novo, propondo acertar a pensão de sua filha na Justiça, e que esta segunda união também não deu certo. Disse que fazia bicos e “muitas mulheres ficam falando sobre pensão. As mulheres são assim...”, com o que os demais concordaram. Disse ainda "Ela acha que qualquer coisa eu vou agredir ela."

Pergunto-lhe o porquê de ela achar isso, ao que ele respondeu "Porque ela é cheia de querer razão.”

Ao ouvi-lo lamentar-se de que tinha quatro filhos e do pouco dinheiro disponível que tinha para pagar-lhes a pensão, pergunto a todos: "e será que tem jeito de a gente planejar quantos filhos quer ter?” Todos confirmam que sim, há meios de se protegerem, e segue uma pequena conversa sobre como os homens sentem-se com freqüência lesados pela mãe dos filhos por estas pedirem a pensão dos mesmos, mas que a questão reprodutiva é algo que comumente fica a cargo exclusivo das mulheres.

Meu comentário visa a questionar alguns pressupostos que venho anotando com base em falas ao longo dos grupos e que refletem o sentimento acima expresso de ver-se 
lesado pela mulher. São eles: 1 - as mulheres querem explorá-los e viver às custas da pensão paga; 2- muitas têm os filhos exclusivamente como meio de vida, explorando os pais das crianças; 3- as mulheres se aproveitam dos homens e os enganam em relação à prevenção, engravidando a contragosto dos companheiros. A idéia de que a prevenção fica a cargo das mulheres e não diz respeito aos homens os impede de pensarem também em prevenção. O que constatamos é o lugar vitimizado a partir do qual estes homens falam, de quem foi enganado, uma vez que a contracepção é pensada como algo do universo feminino, ou, ainda, é comum observarmos uma falta de correlação entre a atividade sexual e a possível gravidez decorrente desta.

Vemos na fala deste usuário como se sente em desvantagem em relação aos outros pais dos filhos de sua ex-companheira, uma vez que estes não pagam nada aos filhos e a ele está sendo requisitado o pagamento.

“Muitas mulheres ficam falando sobre pensão... As mulheres são assim.” O pedido da pensão é verbalizado como uma espécie de punição injusta à qual se sente submetido, desconectada de sua relação com a criança.

Com efeito, esta fala parece ser o resultado, na forma de ataque ou acusação denegritória contra a mulher, do efeito que seu pedido de pensão tem sobre ele. Podemos suspeitar que sua vivência seja também a de ser violentado, convocado a cumprir ou atender a expectativas para as quais não está capacitado por sua condição de trabalho (ou falta do mesmo). Não tendo recursos financeiros para pagar as pensões, a vivência é de impotência e a resposta é agressiva, atribuindo à mulher uma má intenção e a responsabilidade por despertar-lhe tais vivências.

C continua falando de seu caso: "jamais se pode fazer confusão na rua onde mora. Não posso conversar com ela, que ela já fala que eu estou agredindo ela”. 
Ouço-o e, ao terminar, procuro prosseguir com a dinâmica, pedindo que $\mathbf{H}$ apresente seu colega.

B: "ele é I. Ele vem do Jardim São Jorge. A mulher saiu de casa com o filho. Ela foi na Justiça e ele está desempregado, não está podendo pagar a pensão. Dia 20 tem uma audiência para tratar da separação”.

Coordenadora: “você não ficou curioso sobre mais coisas. Vocês conversaram só a parte jurídica?”

I: "homem não gosta de conversar muito”.

B continua: “a separação dele foi igual à minha. Ela trabalha e ele, não”.

Pergunto-lhe então: “o que levava às brigas?”, esclarecendo que o intuito da pergunta não é o de julgar seus motivos: “aqui eu não sou o juiz”.

B respondeu dizendo: "pelo que ele me disse, ela é uma mulher muito grosseira, não quer entender o lado dele.”

I, interrompendo o colega, diz: “Mas não era assim. É que acabou o amor, ela disse que não me amava mais”, em um tom de voz baixo e bastante magoado - os demais ouviam atentos, no mais completo silêncio.

“Tivemos uma briga muito feia, não teve porrada não, mas foi muito xingamento, veio até polícia. Ela foi embora no dia 25/12/2002, foi presente de Natal. No dia 21/12 ela saiu e não disse para onde foi (esse é o dia da briga). Ela está com outra pessoa e dizem que ela está grávida”. Acrescentou que vê a filha, “mas se eu for lá, ela vai querer dinheiro”, ao que vários deles riram, em especial $\mathbf{J}$, em um tom de concordância, como se dissesse que as mulheres sempre têm atitudes como essa. 
Pergunto a B: “então como é que ele faz para ver a filha?” B respondeu dizendo: “ele falou que é liberado”. A coordenadora, sorrindo, comenta: “eu já vi que você tomou o partido dele totalmente”.

I olhou para mim e disse: “eu não quero passar o telefone da minha casa para ela”.

Outro colega, demonstrando preocupação, pergunta a ele: "e se acontece algo com a sua filha?

I diz que preferia que ela entrasse em contato com ele por meio de uma vizinha dele, que estava sempre trabalhando em casa.

Depois, em tom queixoso disse: “ela não deixou nem eu dar um beijo na menina e já perguntou da pensão”.

Percebendo sua aflição, procuro esclarecer a legislação que regulamenta esta questão, dizendo que a autorização às visitas não depende do pagamento da pensão, e que isso era um direito tanto dos pais quanto das crianças.

B concordou com ela, dizendo: "a criança tem que ter contato com os dois".

C pensou em seu caso e disse: "quando paga a pensão, ela obriga a menina a me ver. Quando não está em ordem, eu não chamo ela”.

Em seguida, $\mathbf{P}$ passou a apresentar $\mathbf{J}$ : “esse é o $\mathbf{J}$. Ele tem um filho (diz seu nome) que está com sete anos. Está separado há cinco anos e vive maritalmente com outra. Ele pagava a pensão no valor de $R \$ 420,00$. Ficou desempregado em dezembro e desde então têm ocorrido problemas para ver o filho. Ela tem esperanças de reatar o relacionamento. Agora tem uma ação correndo contra ele”.

Pergunto a $\mathbf{J}:$ “o que você fazia?” Ele respondeu rapidamente: “eu era representante comercial". Explica que ele e a ex-esposa se separaram porque estavam brigando muito. Chegaram a anular a separação, voltaram, mas depois se separaram novamente. Ela vendera e perdera tudo. Diz que a esposa não aceitava a separação e ligava para sua atual companheira, 
quando ele não estava em casa, dizendo que estavam juntos num motel. Por isso, não tem mais telefone em casa, mantendo apenas seu celular particular.

A então propôs: "acho que ela está querendo aproveitar dele”.

J discordou imediatamente: “acho que não. Ela ganha muito bem”.

E propõe que ela deve ter pensado: “agora vou ferrar com ele”.

J concordou com ele e disse que ela usava o dinheiro da pensão para custear sua faculdade.

Em seguida salientou que estava sustentando sua casa com quatrocentos reais. Falando mais alto, disse: “eu tenho como provar".

Digo-lhe, a fim de evitar que se sinta julgado por mim, que sou a representante da Instituição para eles e assim ocupo lugar de autoridade: "aqui para mim você não tem que provar nada, este não é nosso propósito,” ao que $\mathbf{J}$ fica evidentemente irritado.

Penso que a irritação deveu-se a ter entendido meu comentário de forma a proteger sua ex-mulher. $O$ fato de eu ser mulher faz com que, por vezes, seja identificada com suas próprias mulheres, sendo interpretada como defensora delas, ainda que tentasse esclarecer não estar tomando partido de nenhum deles, mas propondo que há outros pontos de vista a serem considerados. Ao longo dos grupos, esse sentimento tende a se dissipar e a idéia de que as histórias têm mais de uma versão é algo que fica mais claro, como visto no relato do grupo de discussão final.

No extrato acima, percebemos claramente o que traz estes homens à Instituição: a necessidade de auxílio jurídico. Vemos também a notada inter-relação entre o exercício da paternidade e o provimento financeiro, sendo que a idéia de exercício da paternidade associa-se de forma marcante como algo do âmbito da possibilidade financeira desses pais. Desta forma, vemos a disputa de poderes entre pais e mães na qual a falta de condição financeira tem a conotação de desqualificá-los como pais, ou, 
ainda, de os impedir de exercerem sua função paterna, demonstrando se sentirem faltosos: “quando não está em ordem eu não chamo ela." Essa espécie de crença, compartilhada pelas mães de seus filhos, as dotam de poderes sobre os filhos, no que parece ser uma disputa por restabelecer um equilíbrio de poderes.

No relato acima vemos, em algumas falas, o sentimento de perda vivido em virtude do abandono da companheira, ou da falta de amor. Assim, a conversa oscila entre vivências de perda, raiva e agressividade, sugerindo pensarmos na existência de uma relação de determinação entre estes sentimentos.

Em seguida $\mathbf{C}$ passou a apresentar $\mathbf{D}$, dizendo: “o nome dele é $\mathbf{D}$. Ele tem dois filhos do primeiro casamento, que vivem com a mãe dele...," ao que D diz: “eu estava sozinho, não tinha como ficarem comigo. Tem também essa filha da pensão (cujo nome não consegue lembrar) e agora tenho 2 filhos do meu atual casamento”.

C: A mulher dele está querendo as pensões atrasadas de 2000 e 2001. Ele pagou e não tem recibo e ela está querendo receber de novo”.

Termina seu relato e então a coordenadora lhe pergunta: "só isso? não tem mais nada sobre a história dele?”

P perguntou: "e a idade dos filhos?"

O próprio D responde: “ela tem cinco anos e quase não vejo ela” (fala somente desta filha, que é o caso que o trouxe à PMFC).

I lhe pergunta: "você paga pensão?"

D: “pago. Ela está alegando que eu fiquei quinze meses sem pagar. Eu tenho testemunhas. Isso foi na época que eu troquei de firma. Eu tenho cinco filhos: dois do primeiro casamento, que moram com minha mãe em Minas, a mulher não tinha condições de ficar com elas. Era alcoólatra.” 
Aproveito a afirmação feita para lançar a seguinte questão, uma vez que verifico que, quando pedem a guarda dos filhos, eles são cuidados por alguma mulher que resida com o pai da criança, como suas mães, irmãs, tias ou uma nova companheira: “para morar com os filhos é preciso ter uma mulher morando junto?”

D explica que não tinha condições de ficar sozinho com as crianças. B concordou com ele, dizendo: "trabalhar e cuidar de criança é terrível”.

I também falou: “o casamento é coisa séria. No momento me encontro só e não a perdôo”.

B faz um longo relato, lamentando as dificuldades de ficar com uma criança pequena e trabalhar, disse que tinha conseguido vaga na creche através do serviço social da Instituição, mas que o menino estava doente há quatorze dias: “eu que tenho que fazer tudo”.

Aqui ouvimos o relato de um homem no lugar mais comumente ocupado pelas mulheres que tem de se haver com a criação dos filhos e o trabalho fora de casa. É interessante ouvirmos a história dele que dá a dimensão da dificuldade na criação dos filhos de um ângulo inverso, feminino. É evidente em seu relato o sentimento de solidão e sobrecarga no exercício desta função. Isso me leva a perguntar:

“e onde está a mãe dele?”

B, em tom raivoso, diz: "ela saiu de casa. Ela fica em mesas de cerveja. Ela tem ido comigo ao médico, mas, se eu não ligo, ela não vem ver a criança. Acho que ela não liga, é o quarto filho dela já. Ela não liga. Eu fico o dia inteiro sem ver ele e fico ansioso para vê-lo. Ela não quer passar a guarda para mim. Eu não quero ficar com a criança sem estar legalizado. Quero que ela fique no sábado com ele. Ela falou que se eu arrumar uma mulher, ela toma o menino de mim.” 
Com o intuito de aliviar sua aflição, dando-lhe um dado real, digo: "se você já está com ele, e ele está bem assim, é provável que a guarda fique com você.”

Ele continua nervoso e agitado, dizendo: "ela está com outro cara."

É comum a alegação de que a mulher não é boa mãe quando ela não corresponde à mãe cuidadora, que mora com o filho, ou, ainda, a mãe que gosta de cerveja, como ouvimos no relato de B. Sua vivência de abandono, solidão e exclusão, “ela tá com outro cara" e 'tenho que fazer tudo," nos remete a uma idéia de que, ao falar da mãe de seu filho, se ressente ao deparar-se com uma representante de mãe divergente de um ideal materno frequentemente encontrado no discurso destes homens. Nessa mesma linha de raciocínio, podemos pensar na vivência comum a todos os meninos, que ao longo de sua elaboração edípica, devendo abrir mão de suas mães - primeiro objeto de amorexperimentam esta ruptura como um processo de exclusão e abandono. A reivindicação de uma mãe cuidadora para seu filho, embora legítima, pode também ser compreendida como uma re-atualização de uma reivindicação passada, da infância.

A acusação feita contra mulheres, sobre sua competência como mães, é ainda, de uma ótica de gênero, algo da mesma categoria que o correspondente masculino: corno ou veado. Acusações tais como ”não é boa mãe” ou “é alcoólatra” estão atreladas a um rígido código de valores cuja resultante é pensar-se que, se ele é um bom pai, que cuida de seu filho, como nos conta $H$, isso se torna prova suficiente de que ela é uma má mãe, não se podendo conceber uma mãe diferente daquela idealizada da infância, que é a forma como estes homens costumam descrever as próprias mães.

Dou continuidade às apresentações.

E passou então a apresentar seu companheiro, dizendo: “esse é o $\mathbf{H}$, veio do Grajaú. Ele conheceu uma mulher, tiveram relações e ela falou que o filho não era dele. Depois que 
nasceu, ela disse que acha que é dele e entrou com pedido de pensão, por isso ele está vendo. O bebê está com quatro meses.

H: Eu só vi ele (a criança) duas vezes”.

H conta ainda ter-lhe perguntado: “como é que você deixou isso acontecer? Você é uma mulher experiente”.

Coordenadora : "mas e aí, tem jeito do homem se cuidar se não quiser ter filhos?”

J logo diz: “Eu me cuido, tive só um filho. Só quero um”.

B: "Antes era tudo festa, agora eu tenho responsabilidade. Há um ano tudo mudou, com o nascimento de meu filh.”.

$\mathbf{H}$ concordou que tem de se cuidar e D disse: "Daqui a 40 dias vou me operar, fazer vasectomia”.

H disse: “o maior medo são as doenças”.

B: “eu só vim me preocupar com isso depois que tive o meu filho”.

$\mathbf{H}$ admitiu que ficou muito chateado e em dúvida diante da situação e $\mathbf{J}$ saiu em sua defesa, dizendo: “ele quer saber se é seu para não deixar ao deus-dará. Pelo que eu estou vendo, ele tem uma boa índole. Eu fico uma semana sem ver meu filho, eu fico louco. Ele podia ter dito: é de outro, tchau. O filho é um pedacinho da gente com vontade própria. No caso dele, ele está tendo boa vontade”.

Aqui, vemos que $J$ parte para a defesa do colega, negando o tema principal que é o da própria responsabilidade quanto à reprodução, e adere a um código de masculinidade no qual o homem não pode ser feito de bobo e cuidar de filho de outro. Pensamos ainda estar implícita nesta formulação uma acusação de caráter moral contra a mulher, atribuindo-se exclusivamente a ela uma função que seria dos dois, ou de cada um como responsável por seus desejos e ações. 
H então disse: “eu adoro a criança, mas eu estou balançando. Eu moro e cuido da minha mãe. Eu fico ansioso para ver meus sobrinhos”.

Depois disso passou a apresentar E, dizendo: “E do Butantã. Ele procurou a casa porque a mulher pegou as três crianças e viajou, disse que ia ficar 15 dias fora e ficou mais de um mês. Quando ela retornou, ela disse que ia trabalhar e levou uma mala com roupas. Ela não voltou na sexta, voltou só no domingo”.

Neste momento, o próprio E começa a falar: "eu tomo conta das crianças. Vendo algodão doce e ela trabalha”.

E retomou a história que contara na entrevista de triagem, dizendo que eles haviam brigado porque ele fizera comida e ela se recusara a comer. Também a acusava de ser relapsa, pois ficava a cargo dele buscar e levar as crianças na escola.

$\mathbf{H}$ interrompeu o relato, dizendo: "Parece que ela está querendo voltar com você...” e $\mathbf{E}$ retomou seu relato, que novamente repetia aquele que havia feito na triagem, aparentando ter uma história pronta para si, que contava da mesma maneira todas as vezes. Dizia que seus filhos estavam sendo maltratados no Paraná (lugar da família da mãe das crianças), e que sua ex-mulher havia dito à tia deles que batesse neles se "bagunçassem” e, por isso, as crianças tinham muito medo de ficar lá.

E conta, rindo, que, quando bagunçam demais, ele diz que vai mandá-los para o Paraná, para que eles fiquem quietos.

H interrompeu-o para complementar: "ele falou que ela disse que não ia dar mais para viver junto”.

E suspirou e continou: “tentei mudá-la e ela não mudou. Ela está dentro de casa porque o escrivão disse para não expulsá-la, estamos separados de corpos. Ela batia no menino de cinco anos e o obrigava a lavar roupa. Ela trabalha fora”. (Esta mulher, segundo a assistente 
social que a havia entrevistado, tinha vários empregos e era quem mantinha financeiramente a casa. Ele vendia algodão doce com uma máquina que ela havia comprado para ele, e como ficava em casa, havia ficado responsável pelo cuidado das crianças).

E contou que após a entrevista (com assistente social da Instituição), tinha conseguido uma vaga para a filha na escola, e que ela estava gostando muito.

Por último e porque já havia se esgotado o tempo, $\mathbf{J}$ apresentou rapidamente $\mathbf{P}$. J: “o $\boldsymbol{P}$ é garçom. Tem uma filha de um ano e sete meses. Está pagando pensão e ela não está deixando ver a filha. Há um certo sentimento entre os dois. Ela pode estar usando a filha para atingi-lo. Eles se separaram só por uma questão financeira e a família dela o considerava um fracassado. As famílias de ambos não querem que eles fiquem juntos”.

Faço uma síntese do que havia sido discutido até aquele momento, indicando que as duas principais questões que haviam trazido a maioria deles à PMFC diziam respeito à pensão e guarda. Esclareço dúvidas de usuários quanto a assuntos relativos aos procedimentos da Instituição e encerro o grupo.

Vale ressaltar, como comentário final deste grupo, a repetição na associação entre pai/provedor financeiro e mãe/cuidadora. Arranjos alternativos ao modelo tradicional de divisão sexual do trabalho, como os verificados nos relatos acima descritos - em que ao pai cabe cuidar dos filhos e à mãe prover a família financeiramente, como é o caso de $\mathrm{E}$-, despertam falas que evidenciam como a ruptura de arranjos tradicionais é vista como falta ou falha. Desse modo, um pai cuidador parece implicar, segundo o ponto de vista do usuário, uma mãe desqualificada em sua função materna, não sendo mencionado em seu relato o fato de ela ser a principal provedora financeira da família. $O$ enaltecimento de sua condição de pai às custas da desqualificação da companheira como mãe, exemplifica um dos tipos de violência a que 


\section{nos referimos, como decorrência de um aprisionamento a padrões rígidos na divisão sexual do trabalho.}

\subsubsection{GRUPO DE 23/04/2004}

Usuários presentes: J, K, L, M, N, P, Q, R, S, H

O grupo começou com os técnicos se apresentando como psicólogos da Casa, pois, como de hábito, havia novos integrantes presentes. Em seguida, justificamos a presença das pesquisadoras em razão da pesquisa que estava sendo desenvolvida na Pró-Mulher e, então, perguntei: “quem lembra o nome de cada um? Vocês que estão chegando, vamos só esquentar. Esse grupo tem a finalidade de a gente conhecer vocês um pouco melhor, dar algum encaminhamento urgente quando for necessário... A gente discute temas que tem a ver com o que traz vocês aqui. Todos aqui têm liberdade para falar o que quiser, comentar sobre o que um ou outro disser, dentro de um clima de respeito com todos.” Na seqüência, expliquei o funcionamento da Casa e a proposta da mediação e sua diferença com relação aos meios jurídicos tradicionais.

K então disse: “mediação é quando junta as duas partes e conversa os dois”.

Coordenadora: concordo com ele e complemento sua explicação, dizendo: "é para que vocês possam resolver que tipo de acordo vão querer fazer e, para isso, a gente precisa se preparar. Nós temos que ouvir o jeito do outro”.

Em seguida proponho a um dos participantes antigos: "Você pode fazer perguntas aos três colegas do jeito ‘aberto,30 para que a gente conheça eles? Pode começar com o Q."

\footnotetext{
${ }^{30} \mathrm{O}$ jeito 'aberto' é como denominamos o tipo de pergunta que possibilite uma gama mais variada de respostas e não uma que já contenha em sua formulação a resposta a ser dada. É algo que não está descrito no relato, mas é regularmente enfatizado, quando praticamos atividades de entrevista. O intuito deste tipo de pergunta é o de
} 
L olhou para o colega e disse: “Q, o que levou você a vir aqui?”

Este é um exemplo de pergunta aberta, sem induzir-se o colega a uma determinada resposta, como havia sido proposto. Esta é uma aquisição das atividades feitas anteriormente em grupo.

Q, de forma objetiva e com muito desembaraço, diz: "inadimplência de pagamento de pensão alimentícia, desde o ano passado. Foi um envolvimento à parte, sou casado”.

L pergunta-lhe na seqüência: “e sua mulher fala o que para você?” Em seguida, tentou justificar a pergunta, dizendo: “é porque tem mulher e homem que entra em acordo os dois”. Q: “com relação ao acordo, a gente está empurrando com a barriga. Os filhos, no meu caso, têm segurado a relação. Aceitar, ela não aceita”.

L: "e com a outra?"

Q responde de forma firme: “não tem contato”.

Isso parece ter um efeito sobre o grupo que logo toma o partido da criança, assumindo uma postura de mudar o comportamento de $Q$, como veremos no que segue.

$\mathbf{N}$ pergunta-lhe se ele via a filha e, com a mesma firmeza (que talvez seja uma forma defensiva de responder, já que iniciava o grupo naquele dia), responde que não.

$\mathbf{N}$ insiste: "você não tem vontade de vê-la?”

$\mathbf{Q}$ responde como antes: "por enquanto não, talvez por causa de toda a situação que ocorreu e também para manter o afastamento da mãe dela”.

Neste momento, $\mathbf{N}$ sugeriu que ele poderia ajudar de outra maneira na criação da criança, já que estava com dificuldades financeiras.

transmitir à pessoa que pergunta que não sabemos as respostas a priori, e cada participante pode ter formulações distintas e particulares. 
Coordenadora: num tom brincalhão, cuja intenção era a de abrandar o 'bombardeio' sobre Q, digo: “mas você já está organizando a vida dele por ele? Que tal, em vez de fazermos sugestões, ou julgamentos, fazermos perguntas para tentar entender os motivos dele?”

A tentativa, por parte do grupo, de influenciar $Q$ é significativa, pois esse tema, sobre quais seriam as funções ou possibilidades de exercício da paternidade que não se esgotariam na questão da pensão, havia sido discutido anteriormente. Assim, vemos que eles absorveram, ou estão questionando no novo participante, questões que também lhes dizem respeito. Contudo, considerando que é o primeiro grupo de que $Q$ participava, intervenho a fim de evitar que ele se iniba e se sinta demasiadamente criticado, o que poderia impedir sua participação mais aberta no grupo.

H, aderindo à posição dos outros colegas, diz: “criança a gente sente muito amor. Se ele conviver com ela uma semana, um mês, não quer largar mais. Eu acho que às vezes tem vergonha de se declarar. É machista”.

$\mathbf{K}$ assumindo a defesa de $\mathbf{Q}$, diz: "o caso dele é como o meu porque vai trazer problema em casa”.

H olhou para $\mathbf{Q}$ e perguntou: “ela é registrada?”

$\mathbf{Q}$ responde: “eu registrei para ver se eu tirava o casamento fora da situação”.

A seguir, peço-lhes que passem a entrevistar um outro dos novos participantes.

$\mathbf{M}$ olhou para $\mathbf{P}$ e perguntou-lhe: “o que trouxe você aqui para a Casa?”.

$\mathbf{P}$, de maneira retraída e olhando para baixo, respondeu: “eu sou separado, tenho uma filha de sete anos. Tive outro filho. Eu quero regularizar o divórcio e a pensão do j. Eu não estou com essa pessoa hoje e eu quero regularizar a pensão do segundo filho. Eu a conheci e calhou dela engravidar. Ele está com quatro meses. A mãe dele é minha amiga hoje. Eu vou pedir uma revisão da pensão da $\boldsymbol{s}$ (primeira filha) e ver o quanto eu tenho que pagar para o $\boldsymbol{j}$ ”. 
A expressão usada 'calhou de ela engravidar' é sugestiva de como a questão reprodutiva e de prevenção é aqui tratada como algo alheio à atividade sexual. Destaco essa fala uma vez que ela é representativa de um tipo de discurso e prática masculina que encontramos muitas vezes, em que a prática sexual é dissociada de sua implicação reprodutiva.

Coordenadora: "e o $\boldsymbol{j}$ e a $\boldsymbol{i}$ foram planejados?" (referindo-se aos filhos dos dois novos participantes.)

Ambos dizem que não.

H começa a falar de seu caso: “o meu a mulher disse que estava tomando comprimido para evitar. Ela disse que tomou comprimido para dor de estômago e ele invalidou o efeito do outro. Será que foi ela que fez a sacanagem?”

Coordenadora: “você acha que o fato dela ter engravidado foi sacanagem?” Em seguida pergunto, dirigindo-me a todos: “e com vocês, como é que aconteceu?”

$\mathbf{N}$ foi o primeiro a dizer: “o meu foi planejado”.

Pode-se pensar que esta fala tem a intenção de responder conforme o que ele acredita ser o desejo da coordenadora: assim responde de maneira a atender à coordenadora, que também é mulher, e diferenciar-se da atitude dos colegas, em relação à qual havia explicitado sua oposição, ao sugerir outras formas de relacionar-se com a filha.

Ouço a explicação de $\mathbf{N}$ e pergunto em seguida: “tem alguém mais que não foi planejado?” 
Q: “o meu não, até porque era um relacionamento que não tinha estabilidade. Foi durante três anos. Eu já não tinha mais contato com ela e ela falou que estava grávida. Eu não usava proteção e ela usava”.

P: "ela dizia que nunca engravidava, tinha tido um outro cara por 8 anos e nada... e comigo seis meses, engravidou. Eu não me sinto enganado. Os meus finais de semana são para os filhos. Não estava na minha idéia, mas aconteceu”.

É interessante verificar, aqui, a repetição de um comportamento sexual que delibera à companheira a questão da prevenção. Contudo, o comentário acima, de $P$, sugere um sentimento de virilidade, ao relatar que em seis meses ele conseguira realizar o que em oito anos o companheiro anterior da mãe de seu filho não conseguira. É freqüente que a gravidez seja significada pelos homens como um atestado de virilidade. Ao dizer que os finais de semana são dedicados aos filhos, podemos destacar dois pontos relevantes: em primeiro lugar, o desejo de diferenciar-se de "pais que não cumprem com suas obrigações”, uma vez que assumir a responsabilidade sobre seus filhos lhes dá dignidade e respeitabilidade como homens. Ao mesmo tempo, de forma paradoxal, ele nos informa o grau de envolvimento que assume na criação destes filhos, acreditando que os finais de semana sejam suficientes, ou, ainda, uma forma intensa de dedicação na criação dos filhos.

S: "eu adoro muito minha criança. A mãe não cuida e não me dá numa boa. Eu quero a guarda e ela não está cuidando dele. Ele já fez seis cirurgias. Ela não tinha paciência, queria sair, tomar cervejinha. O primeiro filho dela, ela deu, e esse, ela não vai dar.” 
Coordenadora: "você quer pedir a guarda por quê? Me dá a impressão de que a idéia de ter a guarda é como ser o dono do filho?”

Faço essa intervenção para esclarecer que, independente de quem tem a guarda, ambos os pais têm o direito de ver e estar com a criança, pois na verdade este é um direito assegurado ao filho. Entretanto, a idéia de pedir a guarda parece conter em si uma espécie de desejo de punição à mãe que o frustra, talvez mais do que querer estar com o filho, atribuindo a ela um atestado de incompetência, ao mesmo tempo em que, conforme vimos em casos anteriores, atesta sua competência como cuidador mais qualificado.

S continua seu relato: “ela nem cuida e nem me dá a guarda numa boa. Eu não sei onde ela está, eu dei a carta (convite regularmente enviado pela PMFC para que a parte contrária venha participar dos grupos de mulheres na Instituição) e ela ainda não ligou. O único conflito que a gente tem é da guarda da criança. Se não der, é juiz mesmo e pronto. Se você for mãe, você vai entender. Agora ela quer que eu cuide da criança para ela ir para balada? Se a minha prima não aceitasse a criança, o moleque ia para o orfanato” (esse comentário refere-se ao fato de ele estar morando na casa de uma prima com o filho).

Vemos aqui como ele procura em mim uma aliada para seu argumento, acreditando que qualquer mãe entenderia seu argumento como algo absolutamente natural. Ao mesmo tempo, cria para mim uma situação de aprisionamento ao indicar como devo ser, caso seja mãe. O sentimento materno, para este homem, é entendido como algo essencialista, da natureza das mães. Observa-se também como o conflito, mais do que algo que diga respeito ao interesse comum em negociarem uma condição 
razoável para o filho, está voltado a uma disputa de quem exerce ou não seu papel adequadamente, explicitando uma disputa de poderes.

S de forma nervosa continua: "uma mãe que é mãe não dá um filho. Se ele deixar de ver o filho não é pai”.

Coordenadora: tento apresentar uma outra possibilidade: “ a gente sabe que às vezes um homem é pai mas não está preparado, ou não desejava ser pai, como estamos vendo aqui. Será que isso também não pode acontecer com as mulheres? Será que todas as mulheres quando têm um filho estão preparadas ou queriam ser mães?”

Observamos que sentimentos de impotência e frustração vividos na experiência cotidiana, nas dificuldades reais com o filho e sua ex-mulher, coadunam-se com a concepção freudiana da eterna busca por completude narcísica e da incessante busca pulsional por satisfação. A vivência frustrante afasta o sujeito da possibilidade desta completude e do que Freud denominou de ideal do ego (o ego que preenche os requisitos de valor preconizados pela cultura e pelo sujeito, sendo o superego a instância responsável por garantir, por meio de vigilância constante, que o ego alcance este lugar almejado), levando-o a buscar 'responsáveis' por esta falta, esta ferida. Assim, justificado por uma lógica de gênero tradicional, calcada num modelo histórico de papéis determinados a homens e mulheres, atribui à ex-mulher a condição de mãe faltante, ou seja, aquela que não se enquadra no ideal de mãe-fusional (que atende a todas as necessidades do bebê). Desta forma, projeta na mulher sua própria falta, atribuindo a ela o motivo de sua vivência de dor. Como veremos logo a seguir, o ideal de mãe presente no imaginário de alguns destes homens é o daquela que 'naturalmente' 
ama seu filho acima de tudo, dedica-se integralmente a ele, pelo simples fato de tê-lo gestado. Não é possível, dentro desta lógica, considerar fatores tais como: depressão pósparto, o não-desejo pela maternidade, o desejo por diversão fora do âmbito doméstico ou familiar, o despreparo, a imaturidade emocional etc.

Neste momento, $\mathrm{H}$ fala de forma enfática: “nove meses, ela não está preparada, como?”

Aproveito a discussão para propor uma atividade: “acho que veio a calhar esta conversa. Vou propor que vocês se dividam em 2 grupos e façam duas listas: uma com as coisas que vocês acham que são do mundo da mulher, e outra, com as do mundo dos homens."

H: “como assim?”

Coordenadora: "Por exemplo, eu estou vendo que, em vários dos relatos de vocês, a questão da prevenção de filhos é algo pensado como sendo do mundo da mulher. É a mulher quem deve pensar nisso e não o homem. Então façam uma lista sobre o que acham que são coisas da responsabilidade das mulheres, ou coisas de mulheres, e outra, do que são coisas de responsabilidade ou do mundo dos homens".

H diz: "quando é a mulher de casa, você fica sem querer usar preservativo. Só uso com mulher de fora. Com a mulher da gente, assim de casa, a gente confia que ela tome comprimido".

L concorda com o colega.

H continua dizendo: "a gente usa preservativo só para evitar doenças."

Coordenadora: "essa é uma das razões pra que se usa preservativo, mas também tem outras finalidades. Por exemplo, eu estou ouvindo aqui várias histórias sobre deixar a questão de 
evitar filhos com as mulheres e depois terem filhos que não foram planejados por vocês. Será que quando a gente quer garantir alguma coisa na vida dá pra deixar por conta dos outros e depois reclamar que não cuidaram como a gente queria, ou devemos cuidar nós mesmos daquilo que é importante pra gente? Pensem nisso.”

Proponho-lhes que se dividam em dois grupos, para discutir e escrever o que pensam, em folhas de papel sulfite, explicando: “cada grupo faz uma lista de cinco itens para homens e cinco para mulheres.”

$\mathbf{Q}$ então me perguntou: "mas isso do conceito que a gente acha natural ou do conceito do mundo de hoje?"

O natural versus o mundo de hoje nos dá a noção do descompasso existente entre o que ele considera ideal, esperado, desejado, em oposição ao que vive atualmente e como tem de se 'submeter' a regras de um modelo de mundo antinatural, que é muitas vezes vivido como injusto. É aquilo a que ele sente que tem de se adaptar ou 'engolir', mas que não está de acordo com o modelo de relação entre homens e mulheres que ele tem introjetado para si (aquilo que denomina natural). Esta fala é paradigmática na medida em que representa um discurso bastante freqüente dos homens que procuram a Instituição. Eles se sentem lesados pelas mudanças do mundo contemporâneo, pela perda de um lugar diferenciado na estrutura familiar. Este tema é bastante discutido no trabalho de Pedro Paulo Oliveira (2002), como já apontado nesta dissertação.

Coordenadora: "é como vocês acharem que é".

$\mathbf{N}$ então propõe: “para ficar mais fácil, por que não divide em direitos e deveres?”

Coordenadora: “tá bom, é uma idéia”. 
Passaram a conversar entre si.

H dizia para os colegas: "não é raiva. É uma coisa que perturba a gente. Foi ela que fez com que a gente se separasse”.

S dizia: “agora eu não quero mais acordo”.

H: "se só o homem trabalha, a mulher tem que cuidar da casa e cuidar da criança. Se ela trabalha, o dever é dos dois."

Enquanto discutiam, eu circulava pela sala e ia comentando o que ouvia deles: “isso é um jeito de se pensar” (ao fazer comentários deste teor, pretendo despertar nestes homens a possibilidade de avaliarem as situações de mais de um único ponto de vista, flexibilizando seus posicionamentos).

Houve dificuldade em realizar a proposta. Vendo isto, penso em usar um referencial comum a muitos (falava-se da novela em algumas ocasiões) e pergunto: “Quem viu lá o Nelito da novela? Ele está morando na casa da Eliete. Fizeram um acordo em que ele cuida da casa pra ela, em troca da moradia, e ela trabalha fora”.

K riu e disse: "ele daqui a pouco tem que vir aqui. Quando duas pessoas moram juntas é assim”.

Todos riram.

Continuo: “às vezes tem outro jeito de pagar as coisas que não é com dinheiro...”

Aqui, procuro utilizar um código comum a todos: o da novela das oito (Globo), a que quase todos assistiam e, muitas vezes, comentavam. Poder observar uma situação, como espectador, assim como se dá com a leitura de livros ou com os contos de fadas para as crianças, ao mesmo tempo em que propicia uma identificação/ou recusa de identificação com o personagem da história, também garante determinado distanciamento afetivo/emocional da questão, de forma a permitir que se pensem e experimentem estas 
situações através da história alheia, que bem poderia ser a deles, já que, embora se vejam como provedores, muitos estão desempregados.

K então diz: “mas só o homem paga pensão”.

Coordenadora: “a mulher não paga porque em geral a criança fica com a mãe, mas, se ficar com o pai, a mãe tem que pagar também”.

J diz: “o homem não faz as coisas direito” (referindo-se ao serviço doméstico e justificando que seria melhor que as mulheres o fizessem, já que o fazem melhor).

Digo sorrindo, a fim de não soar persecutório e disponibilizá-lo a me ouvir : “Ah, essa é uma boa desculpa, hein?”

H então disse: "os melhores chefes de cozinha são homens”.

Vemos que encontrou exemplos que contestam a teoria do colega, mas ainda sustenta uma posição dualista em que as hierarquias são mantidas: há um melhor e um pior.

Digo, ainda, em tom jocoso, pois, embora o tema fosse sério, o clima divertido pode facilitar o entrosamento e a disposição para ouvir comentários que divergem dos seus: “ $a h$, agora os homens são melhores do que as mulheres!”

J: “só dá pra fazer os serviços de casa se a mulher não ficar em cima dando palpites”.

H estava com muita raiva de sua ex-companheira e disse: "se eu não ligar, ela fica cinco, seis dias sem aparecer. Ela não ama o filho. Ela não trabalha, fica a noite no forró e dorme durante o dia. Quando eu ligo, ela vem sem problema nenhum”.

Coordenadora: "vocês estão dizendo que acham importante os pais estarem perto dos filhos, mas vocês estão fazendo isso com acusações.” 
S ficou muito contrariado e disse em tom alto: "você acha que é de ficar de mansinho?" Pergunto-lhe então, com a intenção de questionar um modelo dualista de funcionamento que observo neste comentário, pois, se um é bom, isso faz do outro mau: “você está a fim de ser um bom pai ou de provar que ela não é uma boa mãe?”

H: "ela diz que, se eu arrumar outra mulher, tira o menino de mim. Como ela pode arrumar um cara e eu não posso arrumar outra mulher?”

S, mantendo o tom, diz, referindo-se ao que eu havia dito sobre pagamento de pensão: “agora, mulher vacilou, tem que pagar.”

Tento explicar o que significa ter a guarda de uma criança, já que havia certa confusão, levando a crer que quem não tinha a guarda perdia também os direitos sobre o filho. S estava muito insistente nesta questão, e ficava difícil distinguir se queria garantir a permanência do filho com ele, ou punir a mulher por não ser a mãe que ele desejava que fosse. Digo: “dar $a$ guarda para alguém não significa que o outro perdeu o direito sobre a criança. Isso significa que um dos pais vai se responsabilizar pelo dia-a-dia da criança. Isso não é castigo. É só uma forma de organizar a vida da criança do jeito que for melhor pra todos.”

$\mathbf{S}$ ainda em atitude de rivalidade: "eu acho que ela não está preparada para ficar com o moleque”.

Respondo, dizendo: “É, cada um cuida na medida daquilo que pode, não é isso que estamos vendo aqui?"

N: "existe uma necessidade básica que é de cuidar da criança”.

Q: “o certo seria esse preparo ser natural, nós somos racionais. Esse vínculo é natural”.

A fim de questionar essa posição naturalizada, conto-lhes sobre formas diferentes de organização em diferentes culturas, nas quais os papéis de homens e mulheres são diferentes dos que conhecemos em nossa cultura.

Q, mantendo sua opinião, diz: “a mãe gera um filho, ela já cria um vínculo com a criança”. 
Insisto em questionar esse paradigma, trazendo informações sobre outras situações que levam algumas mães a não poderem cuidar de seus filhos, a fim de apresentar-lhes uma gama maior de possibilidades de pensar sobre o tema: "mas isso não é sempre assim. Têm mães, por exemplo, que ficam deprimidas depois de terem um bebê, que não conseguem nem cuidar de si nem do bebê. Têm mães que ficam muito assustadas de terem que cuidar de um bebê tão pequenininho, e isso é uma doença, chama depressão pós-parto e as pessoas às vezes nem sabem que estão doentes, não sabem como tratar disso”.

N concorda e diz: "é que se encara a palavra doença como frescura, assim como a depressão”.

Continuo: “a depressão é uma coisa muito séria, pode deixar a vida da pessoa bem restrita”.

Q então concordou com eles, dizendo: "acho que algumas mães, a situação cria esses problemas”.

Neste momento, $\mathbf{P}$ interrompeu a conversa, anunciando que precisava ir embora. Tento convencê-lo a esperar até o final do horário, mas ele se irritou e disse: "você não está vendo o meu lado”.

Percebendo sua irritação, concordo com sua saída.

Seria arriscado dizer que o tema da discussão tenha sido um dos determinantes para seu pedido de saída antecipada, embora o tema se voltasse para 'olhar o lado da mulher’ por outro prisma. Sua fala em relação a mim pareceu uma reclamação de que eu 'não estava olhando o lado dele’, e isso pode sugerir que o tema também tenha sido significativo para este movimento. Contudo, ficou bastante evidente que, ao me dizer isso, reconhecia meu lugar de autoridade como coordenadora do grupo, lugar este exercido por uma mulher, que quer lhe prejudicar sem ver seu lado. Ele não se dispõe a 
conversar, e sua maneira agressiva de dirigir-se a mim sugeriu que este homem estivesse se sentindo num lugar submetido, falando de sua vida pessoal para outros homens e sendo coordenado por uma mulher que 'manda' no grupo. Ele se põe nitidamente numa posição de rivalidade comigo, e eu logo concordo com sua saída, pois me pareceu que não haveria conversa possível. Evidenciou-se uma disputa de poderes e me pareceu que naquela situação só haveria uma resolução do tipo ganha/perde. Considerei importante desfazer a disputa, concordando com ele e saindo do lugar de autoridade feminina ao qual ele estava se opondo.

H, mudando o assunto, pergunta como seria a divisão de pensão quando há dois filhos.

Q lhe responde que o juiz também leva em conta a situação das mães.

H e S: “a mãe tem obrigação de dar carinho. É mais a mãe...”, com o que $\mathbf{L}$ e $\mathbf{Q}$ discordaram veementemente, assim como outros. Discutiram essa questão do cuidado dos filhos pela mãe.

S, explicando seu ponto de vista, diz: "É que, antes, ela (sua ex-companheira) não fazia nada, não trabalhava”.

Coordenadora: “E trabalho de casa não é trabalho? Só é trabalho quando é fora de casa?”, ao que ele e os outros concordaram que era de fato trabalho.

Embora, aqui, verbalizem uma concordância acerca de que o trabalho doméstico seja também trabalho, ainda assim verificamos uma valorização do trabalho que resulte em ganhos financeiros, em detrimento daquele necessário na esfera privada. É comum ouvirmos afirmações do tipo "fiz tudo sozinho, criei os filhos sozinho", referindo-se à provisão financeira. Paradoxalmente, vemos ao longo desta sessão uma queixa em relação às mulheres que não exercem o trabalho doméstico ou o cuidado com os filhos. Eles entendem que o vínculo com o filho e o cuidado com este seja algo dado, natural do universo feminino, o que sugere a idéia de algo feito sem esforço, dissociando-se assim da 
noção de trabalho - algo que requer esforço para sua realização. Desta forma, a associação naturalizada da mulher com a esfera doméstica faz com que estes homens ajam de forma crítica, desvalorizando a mulher que não se adapta a esse modelo cultural. Ao realizarem o trabalho considerado feminino - o doméstico e o cuidado com os filhos -, interpretam esta configuração como algo 'antinatural', sendo forçados a desempenhar uma tarefa que não seria atribuição deles. Esta situação, ao contrário de despertar sentimentos de solidariedade e de compartilhamento das funções parentais, leva-os a atitudes críticas em que a moral e a competência da mulher são postas em cheque, por meio de verbalizações agressivas. Verificamos aqui um claro exemplo do que vimos destacando quanto à fixidez dualista de lugares atribuídos a homens e mulheres (o que é trabalho de homem e o que é de mulher), com nítido prejuízo nas relações entre estes e no cuidado com os filhos. As acusações mútuas, apoiadas em modelos idealizados incompatíveis com suas reais possibilidades, os afastam de poderem se exercer com as competências que de fato possuem. Ainda dito de outra forma, a intolerância que é expressa através das acusações feitas às mães de seus filhos, é reveladora de que, ao deparar-se com as reais dificuldades inerentes aos cuidados com os filhos, estes homens frustram-se, atribuindo, então, suas dificuldades não às condições de realidade que os cuidados com os filhos impõem, mas a uma falha da mãe, que, caso estivesse presente, os pouparia de tal condição. É um comportamento que nos leva a pensar num modelo infantil de relacionamento, no qual a criança, incapaz de dar conta de situações complexas, necessita que um adulto - via de regra sua mãe - o auxilie a tornar digerível 0 indigesto ${ }^{31}$.

\footnotetext{
${ }^{31}$ Esse modelo digestivo está descrito em Bion, (1991), em O Aprender com a experiência, e refere-se a uma construção do modelo de pensamento semelhante ao processo digestivo. A impossibilidade de pensar, em decorrência de uma sobrecarga do material a ser pensado, leva o bebê a necessitar que sua mãe realize uma transformação, que chamou de reverie, cuja finalidade é tornar algo pensável, suportável, sugerindo assim uma precariedade do aparelho mental. Encontramos em Freud (1923), em O Ego e o Id, idéia que nos remete a esta quando ele diz que o ego é responsável por impor os processos de pensamento, assegurando um adiamento das
} 
Como já estava perto do horário de terminar, peço-lhes que pensem e digam no grupo se houvera algo, de tudo que havia sido discutido naquele encontro, que tivesse ficado mais marcante para eles, se haviam pensado em algo novo ou diferente, ou, ainda, se alguma coisa daquele encontro ficaria na memória.

$\mathbf{N}$ apresenta a discussão do grupo deles referente à proposta de atividade da seguinte maneira: "o carinho com os filhos ser obrigação do homem e da mulher; a mulher ter direito a uma vida social, mas isso não pode vir antes dos filhos; os filhos devem ser prioridade para ambos".

H retoma a questão da importância do uso de preservativos, dizendo que não se pode ter relações sem preservativos, ao que K acrescenta: "Mas na hora H o homem não desiste”, com o que $\mathbf{M}$ concorda.

N, em oposição a esta idéia, diz "O homem é que tem o controle do sêmen, a mulher não, como ela não controla, o homem tem que controlar... Se fosse o homem que engravidasse, ele teria o medo maior”.

Digo a $\mathbf{N}$ que percebo que, ao falar deste modo, ele estava se colocando no lugar da mulher, e isso fazia com que pudesse pensar com base num outro ponto de vista. A partir disso, pergunto: “Como seria, por exemplo, se os homens é que engravidassem?”

K fazendo careta: “Seria difícil...” (referindo-se à dor e às dificuldades da gravidez.)

H concorda e diz: "Minha mãe teve os filhos na roça, tudo parto natural, sofreu muito no parto do filho mais novo".

descargas motoras, e um ego fraco ficaria sujeito às imposições do id, inviabilizando tal adiamento, cuja expressão se verifica nas expressões acusatórias que visam a descarga de algo insuportável para o aparelho mental. 
A valorização da mãe é tema freqüente. A mãe que tem muitos filhos, ou que apanhava do marido, ou, ainda, a que criou os filhos sozinha, abandonada pelo companheiro, são temas que aparecem de maneira bastante regular. O lugar de destaque e valorização da mãe não se relaciona em nada com o lugar desvalorizado e hostilizado da mãe de seus filhos, estas vistas, em muitos casos, como mulheres aproveitadoras e desonestas, diferentes de suas mães. Há um enaltecimento quase religioso deste lugar concedido às próprias mães, sendo interessante notar que o tema que segue é justamente o religioso.

Entraram em uma discussão sobre concepções religiosas que proíbem os métodos contraceptivos; N e Q dizem que, entre os evangélicos, não se usa contraceptivos.

J diz: “gostei muito da entrevista, de falar da minha história, desabafar”.

L: "eu vou pensar sobre a mulher que tem tempo para ir a balada e não tem tempo para ver a criança. Eu queria saber se existe amor sobre isso aí”.

Respondo-lhe: “às vezes a gente precisa ajudar o outro a poder vir ver os filhos. Pode ser que, para evitar atritos entre vocês, ela também evite ir visitar os filhos.”

$\mathbf{R}$ disse: "Vou pensar no caso dele $(\boldsymbol{H})$ e dele $(\mathbf{Q})$, como têm certeza de que o filho é deles, pois registraram as crianças”.

( $\mathbf{H}$ explicara ter registrado seu filho para evitar atritos com a ex-companheira e $\mathbf{Q}$ dissera que o havia feito para evitar atritos com sua própria família).

$\mathbf{Q}$ disse que se lembraria “das várias histórias, de não me sentir tão sozinho, porque os homens não se abrem”, com o que vários concordaram, que “era muito bom poder falar”.

H concordou com ele e disse: “os outros tiram a timidez. Você acaba notando que tem vários igual você”. 
K disse que gostara de ser "um grupo com várias histórias, a divisão homem e mulher, os direitos iguais”.

M disse que se lembraria dessa questão de "uso de preservativo e pílula".

J disse que pensaria "há homens que não dão nem 100 reais, e eu estou com dificuldade em manter a minha pensão".

N: "Estou pensando como é o grupo das outras partes (refere-se às mulheres). Elas já devem vir conversando desde a recepção...”

Despedimo-nos e termina o grupo.

É interessante observarmos nas falas acima uma inversão do que são tradicionalmente queixas vindas das mulheres: a queixa de que os homens não colaboram, se recusam a prestar auxílio, seja financeiro seja no trabalho cotidiano com os filhos e a casa. Observamos com freqüência que, ao ficar responsável pela guarda ou cuidado com os filhos, isso é compreendido com base numa lógica de que a mulher se mostrou incompetente e não é uma mãe digna. A guarda da criança pelo homem se dá às custas da desqualificação da mulher.

Vemos, ainda, como muitas vezes a prática sexual se dá como algo dissociado de sua função reprodutiva. A reprodução e a contracepção são atribuições femininas, e a gravidez indesejada produz o sentimento de ter sido enganado.

\subsubsection{GRUPO DE 30/4/2004}

Presentes: A, B, C, D, E, H, K, O.

Como havia um aparelho de vídeo na sala, começaram o grupo brincando "vamos assistir novela essa semana...” 
Explico que vamos assistir a um vídeo intitulado: 'Não é fácil', realizado pelo Instituto ProMundo do Rio de Janeiro.

O filme trata do tema da violência de gênero por meio da história de um casal cujo marido se encontra desempregado. Sua mulher tem emprego fixo, portanto, ganhando mais do que ele, o que lhe causa sentimento de humilhação e inferioridade. O filme insinua situações de violência praticadas pelo homem em razão desses sentimentos. Além disso, o filme aborda a dificuldade do personagem em falar de seus problemas com sua companheira ou com colegas, levando-o a um isolamento emocional e a uma pressão interna, uma vez que pauta seu ideal de masculinidade por padrões tais como, citando falas do filme: “ser homem é ter que fingir ser uma coisa que a gente não é?”, ou “ser homem é carregar o mundo nas costas?”

Explico, ainda, que $\mathbf{O}$ estava começando o grupo naquele dia, que tinha uma dificuldade auditiva, e assim lhes peço que falem mais alto e o olhem de frente ao se dirigirem a ele.

O vídeo é apresentado e todos assistiram atentamente, bastante envolvidos.

Ao final, abro a discussão, perguntando-lhes o que haviam achado.

B: "Viu como é difícil ser homem? Passa tanta coisa na nossa cabeça. O vídeo é bem o dia-adia. Agora estou trabalhando, mas fiquei muito tempo desempregado. Antigamente os homens eram machistas” (referindo-se ao que é abordado no filme, em que a mulher está empregada, trabalhando, e o homem não).

Coordenadora: "ele fala sobre estar se sentindo uma merda" (termo usado pelo personagem).

B: “os homens não querem declarar que estão competindo com as mulheres”.

L: “mas ela provocou ele falando do patrão”.

D concordou com ele e acrescentou: “o cara se sentiu lá embaixo”. 

H: “Mas isso não pode levar a ele agredir”.
E: "retrata o que acontece bem claro".

A cena a que se referem mostra o personagem ameaçando bater na mulher, após esta tê-lo provocado, sugerindo que seu patrão era mais homem do que ele. Sua fala é uma agressão/provocação e tem por pano de fundo o fato de ela se sentir sobrecarregada com as tarefas domésticas e financeiras e tê-lo visto no bar, bebendo, quando voltava para casa após o trabalho. Ele, por sua vez, havia parado no bar, pois se sentira constrangido e envergonhado de chegar em casa antes de sua mulher.

Assim, vemos, nesta cena, como ambos, impossibilitados de compartilharem seus sentimentos de solidão, sobrecarga, fracasso e impotência, procuram reequilibrar-se narcisicamente, atribuindo a impotência ao outro, ou livrando-se dela, seja através da violência física (marido ao ameaçar bater na esposa), seja usando de recursos de violência verbal (a mulher que o inferioriza em relação ao patrão), ambas as ações calcadas nos estereótipos hierarquizados de gênero, pelos quais homem que é homem é provedor e forte, e mulher cuida da casa e dos filhos, ganha menos que o marido e valoriza o marido pelos seus ganhos financeiros, numa equação do tipo 'vale quanto ganha'.

D retomou um aspecto do filme e disse: "ele estava batendo na mulher dele porque o pai batia na mãe”.

Aproveitando a oportunidade, pergunto: "vocês acham que quem assiste isso em casa tem mais chance de reproduzir esse tipo de relação em casa com sua família?”

B disse imediatamente: “ tem, a pessoa foi educada daquele jeito.”

O, parecendo um pouco alheio à discussão, possivelmente por seu problema auditivo, diz: “eu fui criado pela minha avó, minha mãe morreu quando eu tinha sete anos. Quando morei com meu pai, minha madrasta maltratava muito”. 
Essa, talvez tenha sido a maneira que encontrou de expressar sua concordância com o que B dissera, parecendo com isso dar sentido a alguma situação de violência em sua própria vida familiar.

Retomando o vídeo, pergunto o que achavam que dera início à briga entre eles.

B disse: “a comparação com outro homem”.

$\mathbf{L}$ tenta justificar o personagem masculino, dizendo que o personagem feminino provocara o homem: “com aquele problema todo, ela vai falar que o patrão dela é que é um homem!”

D traz um dado novo: “eles não tinham diálogo".

E: “ele teve a calma de não bater nela naquela hora, mas tem muitos por aí que picam a mão na cara.”

O filme usa do recurso de um menino, que só é visto pelo marido, e que é o personagem quando criança (o que só fica claro no final do filme). Esse garoto aparece como uma espécie de consciência questionadora, que o faz entrar de novo em contato com seus sentimentos e questiona os valores hegemônicos masculinos que o impedem de conversar. O menino aparece pela primeira vez em cena, justamente quando o personagem levanta a mão e se prepara para bater na mulher.

L concordou com ele e acrescenta: “ela quis dizer que o patrão ganhava mais que ele”.

D novamente fala sobre a falta de diálogo e as conseqüências disso naquela situação: “eu acho que ela provocou, como eles não tinha diálogo, ela ia tomar umas porradas.”

Eles continuaram o debate livremente, com D dizendo: “ali no boteco já começou. Ele achou melhor chegar por último.”

H complementou a idéia, dizendo: "para ele ia pegar mal ele chegar mais cedo."

Neste momento, D disse que não deveria haver diferença para homens e mulheres com relação a isso: “eu acho que não tem diferença”. 
A concluiu, dizendo: “isso é a vida real. A gente tem que participar dentro de casa, o importante é se entender e dialogar." (Vale ressaltar que A vem à Instituição por ter boletim de ocorrência de agressão na família).

Pergunto-lhes: “o que vocês acham, será que ela podia estar se sentindo sobrecarregada?”

A discussão foi acirrada e, embora houvesse uma fala que aparentemente procurasse ‘entender’ ambos os lados e ‘condenar’ a violência física, isso pareceu estar relacionado com o fato de haver três mulheres na sala (a coordenadora e as duas pesquisadoras que anotavam), pois era evidente um sentimento de incômodo grande com a provocação da esposa, bem como uma tentativa de justificar o comportamento violento dele como resposta inevitável àquela provocação.

Assim, essa pergunta é feita com o objetivo de despertar neles a possibilidade de avaliarem a situação de conflito de outro prisma, o do lugar da esposa, a fim de desconstruir-se um pensamento de tipo maniqueísta, certo versus errado.

Na teoria psicanalítica desenvolvida por Melanie Klein (1946), esta descreve um tipo de funcionamento mental, que denomina esquizo-paranóide, no qual predomina um modo de compreensão maniqueísta dos fenômenos, de objetos parciais, ou seja, bom e mau são atributos totais dos objetos.

Não há neste modo de funcionamento, que ela designa como 'posição’ (já que é algo passível de alteração), a possibilidade de uma integração dos aspectos bons e maus do objeto. O intuito deste tipo de mecanismo é livrar-se do que é mau, indesejado ou representa risco para o sujeito, projetando aquilo sentido como indesejado ou perigoso sobre um outro, externo ao sujeito. Esse mecanismo visa restabelecer o sentimento de equilíbrio do ego, evitando uma vivência insuportável de perda de identidade e integridade mental. 
D, respondendo à questão formulada, imediatamente diz que sim, e $\mathbf{A}$ acrescenta: “ ele se separou totalmente da família. Ela estava puta da vida, mas não foi em termos de valores” (dinheiro).

Coordenadora: "vocês acham que eles dois estavam se sentindo sozinhos?”

A disse que sim e $\mathbf{B}$ falando em relação ao personagem masculino: "ele se sentiu sozinho porque é muito machista. É muito difícil se abrir”.

A concordando com B, diz: "nessa hora, o homem conversar com outro e se abrir é muito difícil. As mulheres conversam mais.” (Aqui, refere-se a um momento do filme em que um amigo se aproxima e se oferece para conversar com o personagem. Este recusa dizendo que ‘as coisas vão se ajeitar, de um jeito ou de outro’, insinuando que um desses jeitos pode ser pela violência).

Coordenadora: "e o menino, quem era ele? O que será que representava?”

B e D disseram que o menino era "um anjinho".

A diz: "é alguém que ajudou ele a refletir."

Agrupando todas as falas até então, sugiro: "será que podemos concluir, do que vocês estão dizendo, que, quando eles estavam na competição, eles estavam se sentindo sozinhos?”

Discutindo o vídeo, 0 disse: “o ser humano tem defeitos e qualidades, é mais fácil ver os defeitos. Como a minha ex-mulher, por isso se separou de mim, só via meus defeitos”.

Vê-se que aqui, embora faça uma aparente integração dos diferentes aspectos do ser humano, sua conclusão nos mostra como vivencia de forma parcial sua situação conjugal, vendo-se como vítima e não, como partícipe de uma relação.

Eles continuaram dizendo o quanto era difícil para um homem se abrir. 
A, retomando a discussão sobre a violência doméstica, diz: “as coisas mudaram muito, não é por aí, não é porque viu o pai batendo, vai bater também”.

B concordou imediatamente com ele: "muita coisa mudou, as mulheres têm mais direitos. Antes os homens batiam até tirar sangue da mulher com um facão grande assim (mostra com as mãos). Problema de marido e mulher, ninguém metia a colher”, ao que K gargalha.

Nesta sessão, o tema da violência é bastante explicitado, não somente no filme como também nas falas dos participantes, como se lê acima. De maneira geral, verificamos uma postura mais à vontade que os levou a falarem de forma bastante livre sobre o tema, relacionando-o com suas vivências pessoais.

No último trecho acima, a lembrança, por $K$, da violência praticada não desperta compaixão ou espanto pelo ato praticado. Ao contrário, suscita risos. Podemos entender este comportamento como algo que se relaciona com 'as boas lembranças dos bons velhos tempos', quando era facultado ao homem bater em sua mulher, sem que isso implicasse qualquer tipo de penalidade ou problema. Há que se lembrar que todos estes homens que nos procuram o fazem porque, como dizem, “hoje a situação da mulher é diferente”. De outro modo, o serviço da PMFC e o grupo de homens nem ao menos se justificariam, e seus lugares de superioridade hierárquica estariam garantidos.

Observamos nesta fala aquilo que Pedro Oliveira (2002) descreve como o desejo de manutenção dos lugares hegemônicos como um lugar vantajoso. Associando sua tese à compreensão edípica, sabemos que a elaboração para a saída do Complexo de Édipo no menino se dá em dois tempos: o temor suscitado pela ameaça de castração, caso persista em seu intuito de querer a mulher de seu pai, sua mãe. Contudo há uma promessa futura em jogo que lhe permite abrir mão deste desejo, isto é, a de que terá no futuro aquilo que seu pai tem agora, mas com uma outra mulher que não sua mãe. 
Podemos pensar que estes homens, já lesados na esfera social como cidadãos, vêem-se duplamente lesados ao terem de abrir mão daquilo que outrora fora uma condição garantida de superioridade masculina, da qual seus pais desfrutaram.

A propósito da discussão e com o intuito de trazer outros dados sobre a violência em geral, comento: “eu ouvi ontem no rádio que só nós (no Brasil) representamos 11\% dos homicídios no mundo. Que vocês acham disso?”

A conversa segue num tom que poderíamos caracterizar como defensivo, pois um dos participantes dizia que não eram violentos e que a situação das mulheres tinha passado por muitas mudanças.

A, concordando com ele, diz: "você não pode dar um tapa num filho hoje. Isso eu acho que está muito errado”.

Aproveito essa fala e pergunto: "você acha que os homens ficaram mais impedidos ou prejudicados com as mulheres tendo direitos?”

B respondeu a pergunta, dizendo: “homem geralmente é muito machista”.

Coordenadora: o que é ser machista?”

B: "Mandar, exigir que a mulher obedeça, querer dar a última palavra, achar que ele tem que carregar a casa nas costas, dar a última palavra."

Vou anotando essas definições no quadro.

D complementou, dizendo: "não aceita que a mulher interfira".

B continuou: “ele aceita opinião, mas ele tem que dar a última palavra”.

É interessante notar que falam dos homens como 'eles' e não 'nós'. Há um distanciamento deste tipo de comportamento violento num discurso que busca uma aliança com as mulheres presentes no grupo. Pode-se levantar como hipótese, que esta 
forma de discurso visa a despertar no outro (as mulheres do grupo) um olhar aprovador. Algo como 'não somos como estes homens, somos diferentes, queremos ser bem vistos, valorizados'. Observamos, assim, a ambivalência presente nesta fala, que, ao mesmo tempo em que expressa os desejos de dominação do homem sobre a mulher, evidencia também seu desejo de ver-se valorizado através do olhar feminino, numa clara mostra de que os poderes são instáveis e mutáveis.

D então perguntou aos colegas: e o que é dominado pela mulher, o que é ele?”

Neste momento, houve um grande alvoroço na sala, A: “É o amor. O cara aceita tudo porque não quer perder ela.” Outros diziam que ele era um trouxa e seria considerado corno (sic).

A idéia de que o amor transforma o homem em uma pessoa submetida à mulher revela a associação entre afeto e fragilidade ou fraqueza. Assim, conforme já dissemos anteriormente, o homem que se deixa levar pelos afetos se aproxima do que é, do ponto de vista de um modelo estereotipado ou tradicional de gênero, próprio do feminino, caracterizando-o como um não-homem, ou corno. A necessidade de manter a hierarquia dominante mostra-se, assim, como condição necessária para a manutenção de sua identificação masculina.

Pergunto-lhes, referindo-me aos comentários feitos por D e A: “é um homem que não é homem?"

D responde dizendo: “ pega mal. Eu não sou machista, mas para mim pega ma”l.

L: “tem vários casos assim na minha família.”

K: “Os vizinhos contam de caso assim, que pega mal ser dominado pela mulher”. Coordenadora: “Os vizinhos chamarem de corno?” 
D: “Isso de chamar de corno pega muito mal”.

E: “Tem que ser igual, os dois dominados”.

D: “E esse negócio das mulheres quererem sair para o forró, o baile?”

A disse que não aceitava. D diz: "Tem que ter confiança entre ambos”, com o que $\mathbf{E}$ concordou.

A disse que isso acontecera com a mulher dele: "Ela disse que queria ir para o bar encontrar uma amiga, como os homens podem”.

D disse: “Esse direito elas já conquistaram.”

Coordenadora: “É, teoricamente sim (referindo-se aos direitos), mas, na prática, o que se pensa se a mulher falar que quer sair?”

A e H disseram: "Já se pensa que é outro homem."

D relembrou que isso acontecera com B: "Foi invertido, ele viu ela no bar, quando estava com o filho no hospital”.

B: "Eu saio para procurar mulher, mas se tenho mulher em casa, não. Vou para casa, estudar”.

Coordenadora: "Então, quando as pessoas se casam, não podem mais se divertir? Não podem ir no forró, dançar etc? Assim, ser casado pode ser muito chato, não?...”

B disse: "Vou sair, correr o risco de tomar um tiro, com minha família em casa?!"

D: “É bom sair junto. Eu e minha mulher vamos no forró. A gente até dança em casa antes, ensaia uns passinhos...”, com o que A concordou.

D: "Se se está sozinho e vai no forró, é para tentar arranjar alguém", com o que B concordou.

A: "No casamento é muita cobrança..."

Retomo a discussão sobre o vídeo, perguntando o que o menino (o menino que só o personagem via e que questionava suas ações e idéias) representava. Alguns disseram que o 
menino o fez tentar conversar. Também relembro a cena do filme em que a esposa tinha lhe ouvido quando o marido decide conversar com ela sobre seus sentimentos. Pergunto-lhes ainda, se achavam que o menino podia estar representando os sentimentos 'não autorizados' do personagem, com o que vários concordaram.

D comenta que percebeu uma diferença na postura dela quando a ajudou com o jantar (cenas do filme em que o garoto imaginário questiona o porquê de o marido ficar olhando sua mulher colocar a mesa e servir o jantar, sugerindo que ele a ajude. O marido, contrariado, concorda ‘desde que você - garoto - pare de falar, ta?’ Ao receber a ajuda do marido, a mulher o olha com olhar perplexo, como se algo estranho estivesse se passando com ele.

O diz que conhece “um advogado que largou a mulher”.

Pergunto-lhe o que quer dizer com aquele comentário, ao que ele responde: “isso também acontece com quem tem estudo”.

Comentário interessante deste homem quase sem estudo e com problema auditivo que o faz parecer alheio ao que acontece. Possivelmente ele estava explicitando o que verifica como diferenças de capital simbólico e classe social entre a coordenadora e ele, numa fala de intenção crítica sobre ter sentido que a exibição do filme e as minhas falas fossem uma forma de imposição de um saber sobre outro, assim como caracterizado por Bourdieu (1993, p.695), com sua definição de violência simbólica, referindo-se à dessimetria social entre pesquisador e pesquisado. De qualquer forma, explicita seu desejo de sair de um lugar de exclusão e desvalorização como representante de um comportamento que estava sendo criticado pelo grupo, o comportamento violento e a falta de diálogo. Vale lembrar, contudo, que o casal retratado no filme é da mesma classe social a que o grupo pertence. 
Alguns disseram que “educação ajuda no diálogo”.

Pergunto-lhes se isso ocorrera no vídeo.

A insiste: "As coisas mudaram. Hoje se tem que conversar, dividir, ajudar em casa."

Ainda referindo-me à cena do filme, pergunto sobre por que o personagem elogiara a comida da esposa, e D responde: “as mulheres adoram que se elogie a comida”.

Coordenadora: "Mas todo mundo gosta de elogio, não é?...”, com o que concordaram e então, pergunto: “E por que será que todo mundo gosta disso?”

E diz: "É um carinho...”

A: "Seu ego vai lá em cima.."

Coordenadora: "Você se sente alguém, respeitado quando valorizam o que você faz?"

E: "Se sente amado."

Coordenadora: “Dá pra elogiar, se a gente estiver se sentindo uma merda?” (essa é a expressão usada pelo personagem do filme ao relatar como se sentia).

Respondem vários deles: “De jeito nenhum”.

A: "Você não vai encher a bola do outro para ficar mais por cima de você".

Questiono sobre a importância (referindo-me ainda ao enredo do vídeo) “de o casal ter diminuído a competição entre eles para conseguir conversar, se entender.”

Retomo a discussão a respeito de os homens não conversarem sobre o que sentem e pergunto-lhes por que achavam que isso acontecia.

E: "Por machismo".

Pergunto-lhes se conversam ou alguma vez conversaram sobre essas questões com outros homens, ao que A diz: "Não as coisas do dia-a-dia, mas comecei a conversar mais no último ano".

Coordenadora: “Vocês acham que esse tipo de conversa é possível aqui no grupo?”, ao que todos responderam afirmativamente. 
Coordenadora: “E por que não fora daqui?”

B e D: "Porque aqui todo mundo tem um problema e sabe disso. Fora daqui não, você não sabe se o outro tem problema."

Coordenadora: “e com a mulher, também é difícil se abrir?”

B diz que sim “porque se tem medo que ela não aceite.”

Indago: "será que é porque os homens acham que elas esperam que ele seja o cabeça da casa?”

A diz que sim em poucas palavras: “ a mulher não mudou muito ainda não. Elas querem sombra e água fresca, ela ainda procura um cara que tenha estabilidade."

Coordenadora: “Você acha, então, que as mulheres são folgadas?”, ao que vários riram, pelo inusitado do comentário.

D diz: “Mas também não é justo. Você está mal, vai procurar alguém para afundar mais ainda?”

Era o último grupo de vários deles e já estava no horário de terminar. Aviso que está na hora de encerrar, agradecendo a todos a presença e dizendo que a discussão havia sido muito boa. Todos concordam entusiasmados. Saem falando que havia sido muito bom e fazem questão de se despedir de todos com cumprimentos de mão, inclusive dos técnicos e das pesquisadoras. Há um clima de envolvimento afetivo na despedida.

Em atendimentos em grupo, o momento de despedida é sempre um momento vivido com pesar. A separação não é algo que passe despercebido e o rompimento do vínculo traz um sentimento de perda. Vemos isso nesta última sessão, pela manifestação de entusiasmo, pelo desejo de todos se despedirem de todos, pelo grande envolvimento. 
A separação e a perda de vínculos importantes é também o tema desses homens, não só nesta sessão mas como motivo que os leva a procurar a Instituição.

Acredito que o ambiente propiciador de conversas de cunho pessoal, tratadas com respeito por todos, nestes encontros, é favorecedor do aparecimento de manifestações mais espontâneas de afeto, assim como vimos neste grupo final.

Há também, como vimos nas falas acima, um sentimento de identidade entre os participantes, que, ao se verem em situação semelhante à de outros colegas, sentem-se mais acolhidos, sendo-lhes, assim, possível falar de assuntos que, em outro contexto, se sentiriam expostos à humilhação e em situação de risco quanto à exposição da sua masculinidade. Freud (1921, p.96), em seu trabalho sobre grupos, sugere que, se os indivíduos se unem num grupo, numa unidade, deve haver algo para uni-los, um elo, sendo este o que daria a configuração do grupo enquanto tal. Acredito que o elo comum mais visível seja exatamente este processo de encontrar pares com quem possam compartilhar suas idéias e sentimentos. Entretanto o grupo se constitui de indivíduos heterogêneos, ainda que seja visível a tendência à homogeneização nesses grupos, assim como lemos no referido artigo freudiano. Embora esta tendência seja o que dê o caráter de força e estabilidade ao grupo, é também interessante verificarmos a existência de posicionamentos diferentes, levando a discussões que questionem o estatuto de verdade absoluta de algumas colocações feitas. Sendo assim, procuramos abarcar aquilo que é homogêneo - uma vez que isso dá vida ao grupo --, sem perder de vista e distinguir o heterogêneo, ao atribuir sentidos e propor alternativas às falas dos participantes, resgatando o que é próprio de cada um.

\subsection{COMENTÁRIOS}


Verificamos nesta população o predomínio de um tipo de pensamento pautado pelos ideais tradicionais de gênero. Sendo assim, costumam apresentar idéias bastante definidas quanto a valores de conduta, comportamentos, idéias sobre o que é certo e errado, mostrando pouca flexibilidade em relativizar suas opiniões. Apresentam freqüentemente narrativas prontas e inflexíveis, atribuindo ao "outro” o motivo de suas disputas. Chegam à instituição colocando-se amiúde numa atitude de passividade receptiva, esperando que os técnicos da casa atendam às suas demandas de forma assistencial ou paternalista, ou seja, não se vêem implicados com a própria história, esperando que “as autoridades” arbitrem sobre seus destinos. A idéia de uma lei “justa”, definindo os encaminhamentos de suas vidas, carrega em si a noção de hierarquia e poder, em que os mais poderosos determinam os destinos dos menos poderosos, reproduzindo a mesma dinâmica presente nas relações conjugais regidas pelos padrões tradicionais de gênero. Assim, o trabalho visa desenvolver nos participantes do grupo condições de empoderamento e protagonismo, rompendo com este modelo hierárquico, veiculando uma nova ideologia que pressuponha a equidade, parceria e responsabilidade, formando sujeitos transmissores ou agentes de transformação de uma nova forma de funcionamento social. Os conceitos de empoderamento e protagonismo, embora já um tanto desgastados pela grande proliferação de ONGs nos últimos anos ${ }^{32}$, estão formulados mediante uma concepção do ser humano como um indivíduo capaz de enfrentar situações de dificuldade, refletir sobre elas e tomar decisões de forma responsável. Em outras palavras, que sejam capacitados a responsabilizar-se por suas próprias vidas, seus atos, bem como as conseqüências decorrentes destes (MUSZKAT, S., 2003, p.192).

É importante ressaltar que o que propomos ao falarmos de empoderamento não se refere a tornar homens - muitos dos quais violentos - mais poderosos no sentido das relações

\footnotetext{
${ }^{32}$ Sugiro a leitura da dissertação de mestrado de Marcelo Gustavo Aguilar Calegare (2005), desenvolvida no departamento de Psicologia Social do Instituto de Psicologia da USP, sob orientação do Dr.Nelson da Silva Jr, para a compreensão aprofundada do tema das ONGs no Brasil.
} 
de poder, da ocupação de um lugar de domínio na hierarquia conjugal. Isso, ao contrário do que visamos - encontrar meios alternativos de comunicação não violentos, para as relações entre homens, mulheres e seus filhos - nos levaria a solidificar ainda mais relações pautadas por poderes fixos, constituídos. Acreditamos que a necessidade de manutenção de dominação e de poderes fixos constituídos não representa uma condição de poder, mas pelo contrário, uma falta do mesmo, que faz com que homens tenham que se apegar de forma adesiva a padrões tradicionais de masculinidade, acreditando que estes serão garantidores de sua identidade masculina. O empoderamento consiste, a nosso ver, em poder abrir mão da obrigatoriedade em funcionar dentro de preceitos rígidos, podendo contar com uma gama de recursos identificatórios mais ampla. Ou seja, quando a manutenção da identidade masculina depende de poucos indicadores tais como dominar mulher e filhos, ou ser o provedor exclusivo da família, ao deparar-se com a alteração destas condições, o homem sente sua identidade ameaçada, sobrando-lhe como recurso débil e precário de resgate de identidade o uso da violência. Assim, entendemos que o uso da violência não se apresenta como recurso de poder, mas sim evidencia o que chamaremos de desamparo identitário, construído a partir de ideais culturais nos quais estes homens ficam mergulhados em função da precariedade da rede de significados de que dispõem como definidores do que é masculino e feminino. A concepção de desamparo identitário se contrapõe à noção de uma rede identificatória diversificada, na qual a base de sustentabilidade do indivíduo se amplia, dando-lhe mais recursos pessoais que lhe garantam um maior equilíbrio narcísico. Este tema será desenvolvido posteriormente baseado nas teorias psicanalíticas. 


\section{O UNIVERSO MASCULINO SOB DISTINTAS ÓTICAS}

Neste capítulo, dando continuidade ao capítulo anterior, visamos ampliar a compreensão a respeito das formas de funcionamento que observamos nas falas dos homens dos grupos relatados. Buscaremos ampliar nossas formulações a partir de dois vértices: nos autores que se voltaram ao universo masculino e na metapsicologia freudiana. Com base nessas duas fontes, procuraremos elaborar uma compreensão acerca do que identificamos como a falta de uma rede maior de significados no discurso destes homens que os impede de poderem manter sua noção de identidade masculina, levando-os a assumir uma posição maniqueísta e violenta em relação às mulheres e a eles mesmos. Dividimos o capítulo em 4 sub-capítulos, iniciando com OS AUTORES, que indica autores e pesquisas de referência nos estudos sobre a masculinidade e situa o leitor sobre alguns dos importantes estudos que vêm sendo realizados. A seguir em, DE QUAIS HOMENS FALAMOS?, são definidos aspectos tais como classe social, nível de escolaridade, acesso e inserção no mundo público e o tipo prevalente de ideologia quanto ao que consideram fatores de garantia da masculinidade.

O terceiro sub-capítulo, CONTRIBUIÇÕES PSICANALÍTICAS, propõe uma reflexão inteiramente ancorada na teoria psicanalítica, com base nos trabalhos de Freud que tratam das questões sociais, da teoria das pulsões e do tema da agressividade. Também articulamos os conceitos de violência de gênero com o conceito de violência fundamental desenvolvido por Isabel Kahn (2002), bem como com a concepção freudiana de desfusão pulsional e sadismo. Nosso intuito é o de identificar as especificidades referentes ao tipo de violência que abordamos neste trabalho, procurando distinguir, quando possível, as afinidades e divergências desta - a de gênero - com as duas outras mencionadas. 
O último item, E AFINAL... POR QUE OS GRUPOS?, analisa uma entrevista, nos moldes de um grupo focal, realizada pelas pesquisadoras do projeto de pesquisa (Unicamp/PMFC) com um dos grupos de homens, após a realização de quatro encontros consecutivos. Nesta entrevista coletiva, vemos aquilo que nos motivou a realizar esta pesquisa, ou seja, a possibilidade transformadora deste tipo de prática e a possibilidade de pensar-se na replicação de projetos que envolvam homens, diferente do que têm sido as políticas públicas em violência até a atualidade.

\subsection{OS AUTORES}

Desde o final dos anos 80, muitos estudiosos da área das ciências sociais vêm se debruçando sobre as questões relativas à masculinidade, ou, ainda, como definido por Connel (1995), referência importante nos estudos sobre masculinidades, aquilo que conceituou como as várias masculinidades (VALDÉS \& OLVARRÍA, 1997; CONNEL, 1995; KAUFMAN, 1999).

Verifica-se a existência, em diversos países que não o Brasil, de uma diversidade de programas voltados à discussão sobre a masculinidade ${ }^{33}$, seja pelo vértice dos estudos de gênero, ou através de programas para jovens rapazes, ou ainda como resposta a mudanças na sociedade ocidental contemporânea. Em outras palavras, assistimos à entrada significativa das mulheres no mercado de trabalho e sua responsabilidade total ou parcial no provimento familiar, resultando numa crise das relações entre homens e mulheres, cujos padrões de relacionamento, bem como da divisão de trabalho, se apóiam num modelo hegemônica de masculinidade.

\footnotetext{
${ }^{33}$ Refiro o leitor ao livro Masculinidades: poder y crisis (VALDÉS \& OLAVARRIA, 1997), como também o relatório realizado por Emily ROTHMAN, BUTCHART \& CERDA, Intervening with Perpetrators of Intimate PartnerViolence: a global perspective. Geneva: ed. World Health Organization, 2003, para uma rica listagem de programas voltados ao trabalho com homens, em distintos países.
} 
Valdés e Olvarria (1997) expõem interessante listagem feita por Clatterbaugh de 6 tipos prevalentes de perspectivas de estudos ou programas: 1) uma perspectiva conservadora, que considera "natural” o papel de provedor e de dominância social e política masculina, 2) a pró-feminista, que enfatiza o caráter opressor/oprimido entre homens e mulheres, 3) a dos Men's Rights, que ressalta o aspecto danoso ao homem obrigado a corresponder ao sistema hegemônico masculino, sofrendo ainda danos maiores como conseqüência do movimento feminista, 4) uma perspectiva espiritual, que acredita que a masculinidade deriva de padrões inconscientes profundos, revelados através de rituais e mitos, 5) uma de cunho social, que acredita que as diferentes masculinidades são definidas pelo tipo de trabalho exercido e pelo grau de poder e controle sobre o trabalho de outros e, finalmente, 6) a que descreve uma masculinidade universal, que contém uma diversidade, em razão das distintas experiências dos homens, e que esta diversidade estaria igualmente presente nos diferentes agrupamentos e grupos étnicos (idem, p.12).

Autores como Connel (1995), Kaufman (1999; 2003) ${ }^{34}$, e outros voltaram seus estudos principalmente para o que se convencionou chamar "masculinidade hegemônica”, incompatível não somente com melhores relações entre homens e mulheres, como também com a possibilidade de haver uma diversidade maior de vivências dentro da condição masculina. Estes autores dedicaram-se a elaborar programas dirigidos aos homens cuja finalidade é o enfrentamento e a mudança de comportamento - diferente da punição - em relação ao problema da violência praticada contra mulheres, da violência experimentada no universo masculino (freqüentemente entendida como atributo natural masculino), e da propagação de comportamentos violentos para as gerações seguintes, em virtude da repetição

\footnotetext{
${ }^{34}$ Kaufman desenvolveu o que chamou de "The 7 P's of Men's Violence”, procurando identificar modos de construção da identidade masculina na cultura, que estariam pautados por: 1-patriarchal power, 2-privilege, 3permission, 4-paradox of men's power, 5-psychic armour of manhood, 6-psychic pressure cooker, 7-past experiences. Estes modelos referem ao modo de criação dos homens em nossa cultura, e seriam facilitadores das práticas violentas masculinas.
} 
de modelos aprendidos. Seus trabalhos têm-se pautado por tentar envolver os homens em programas de conscientização, que visam diminuir as diferenças nas relações de gênero e promover a equidade.

Connel (1995), em seu livro intitulado Masculinities, questiona a propriedade de se caracterizarem os estudos sobre a masculinidade como uma real disciplina, uma vez que identifica a diversidade de padrões de masculinidade existentes dentro de uma mesma cultura, que não se esgota naquele caracterizado como hegemônico. Como exemplo, cita estudo realizado por Paul Williams com alunos de escola publica inglesa, que identifica o surgimento de um grupo de masculinidade de oposição à dominante, embora esses jovens compartilhassem de um mesmo ambiente institucional. Encontra estudos semelhantes realizados em escolas de elite na Austrália, levando-o a considerar ainda que reconhecer a diversidade é insuficiente, sendo fundamental, segundo ele, identificar as relações existentes entre as diferentes formas de masculinidade. Por meio destas relações, que podem ser de aliança, exploração, dominação e submissão, ele verifica que também no universo masculino criam-se grupos de excluídos e incluídos, levando o autor a postular uma política de gênero na masculinidade. Vemos, nesse tipo de abordagem, que aquilo a que Connel denomina gênero diz respeito, portanto, às relações de poder e dominância, e a conseqüente submissão e/ou exclusão de um determinado grupo, independendo, nesse enfoque, do sexo biológico.

Essa posição difere daquela adotada por autoras feministas e cientistas sociais e antropólogos dedicados aos estudos de gênero (Scott, Weeks, Butler, Barbieri, Arilha, e outros), que priorizam nestes estudos de gênero as relações de poder existentes entre os sexos e as formas autorizadas de sexualidade. 
No entanto, mais adiante em seu trabalho, Connel parece não sustentar inteiramente este posicionamento, uma vez que configura como objeto de estudo, as relações de gênero, enfatizando a noção de um masculino que só pode ser entendido ou estudado, em relação ao feminino (1995, p 44). Define masculinidade como:

configurações de práticas estruturadas por relações de gênero (ou seja, relações de poder e interesse de dominação ideológica - comentário nosso).Elas são inerentemente históricas, sendo a construção e reconstrução processos políticos que afetam o equilíbrio de interesses numa sociedade bem como a direção das mudanças sociais (idem, p.44).

Concordamos, contudo, com a colocação de Connel de que, em se reconhecendo a diversidade dos tipos de masculinidade, não podemos tratá-los como categorias fixas (idem, p.38), como também foi verificado por Pedro Paulo de Oliveira (2000) em seu estudo sobre masculinidade, ao ressaltar as especificidades de funcionamento dos diferentes agrupamentos em função de sua condição socioeconômica e grau de escolaridade.

Outros autores (CORSI, DOHMEN \& SOTÉS, 1995; OLIVEIRA, 2002) apresentam trabalhos que consideramos relevantes, voltados aos estudos sobre a violência conjugal e a construção da masculinidade. Pedro Paulo M. de Oliveira (2002), em sua tese de doutorado, desenvolve uma interessante reflexão crítica a respeito do que se convencionou chamar de “crise da masculinidade”. Questiona o posicionamento daqueles que, argumentando a favor da existência da crise, atribuem aos homens a sujeição a um lugar de opressão em razão da obrigatoriedade em terem de atender aos preceitos de uma masculinidade hegemônica. Em suas palavras, "Há quem veja a condição masculina sob uma série de prescrições sociais constringentes, mas alguns estudos apontam entre homens de camadas populares uma valorização explícita desta mesma condição” (idem, p.89, grifo nosso). Refere-se 
explicitamente à ideologia veiculada em movimentos do tipo citado acima (Men's Rights), em que o homem, ao contrário de ocupar um lugar de dominação, seria, na verdade, vítima desta ideologia masculina. O autor justifica seu questionamento dizendo que "a crise, se de fato existe, está fundada em mudanças 'sócio-estruturais' que devem abalar o regime patriarcal, afetando assim o próprio valor social da masculinidade” (idem, ibidem).

A ressalva de Oliveira que queremos destacar é quanto à necessidade de se considerar o tipo de inserção social de cada indivíduo quando se pretende entender códigos de valores adotados, não se podendo, portanto, em concordância com diversos dos autores citados (CONNEL, ACOSTA E BARKER), falar em masculinidade de forma genérica.

Oliveira vai mais além, definindo o que chamou de discurso vitimário sobre a masculinidade, “uma vez que (este discurso) enfatiza a condição masculina como vítima de um conjunto de fatores sociais e psíquicos” (2000, p.90). Cita, em sua argumentação, as diversas estatísticas (repetidas não só nos diversos autores como na maioria das pesquisas atuais sobre violência), nas quais se verifica que os homens são as maiores vítimas de acidentes, homicídios, crimes violentos e abuso de álcool e drogas. Tais dados levariam a confirmação deste lugar de maior vulnerabilidade - ou vitimação, como ele denomina -, invertendo assim o discurso feminista que identifica a mulher como maior vítima de violências. Este argumento, contudo, não invalida o fato estatisticamente comprovado quanto ao alto índice de mortalidade masculina causada por mortes violentas. Constatamos também que, se não por intermédio dos dados publicados com certa assiduidade na mídia, ainda assim esta não é uma informação desconhecida de muitos deles, uma vez que há diversos relatos, nos grupos que atendemos, que referem perdas de parentes próximos, amigos, filhos, vizinhos ,como resultado de mortes por violência. No entanto, esses fatos, embora contados com pesar, não parecem interferir significativamente num questionamento 
acerca de alternativas de comportamento que promovessem uma diminuição destes atos violentos.

Corsi (1995) descreve trabalho desenvolvido por ele com grupos de homens violentos na Argentina e procura traçar um perfil de personalidade daquilo que encontra em comum nos homens que praticam violência. Irá caracterizar a violência como algo que se dá em razão de um desequilíbrio de poder, afirmando que o ato violento é uma forma de abuso de poder. Enfocando, portanto, o ato violento como um ato de desejo ${ }^{35}$ que visa a ocupação e/ou manutenção de um lugar de poder, recusa a justificativa, muitas vezes adotada, que associa atos violentos ao uso de álcool ou a psicopatologias, isentando o praticante de sua implicação com suas ações. O álcool, por seu caráter de inibidor de censuras, freqüentemente viabiliza uma maior impulsividade, prestando-se assim a ocupar um lugar de 'outro' responsável, depositário das projeções do sujeito, eximindo o indivíduo de responsabilizar-se por seus atos. Vimos, nos relatos das sessões, como a violência praticada é amiúde justificada por fatores externos, sejam ele o álcool, ou ainda mais freqüentemente, o comportamento da companheira, numa atitude de não-comprometimento com as próprias ações. Algo como 'não tive culpa, fui levado por isso, ou aquilo'. Assim, ele afirma, logo ao início de seu trabalho, que a violência praticada por homens não tem classe social. Diz ele:

\footnotetext{
${ }^{35}$ Com base na teoria das pulsões, qualquer ato humano deve ser pensado como um ato permeado pelo desejo. Dessa forma, não poderia discordar desta colocação, muito embora penso que seja essencial que diferenciemos entre uma conduta movida por um desejo de destruição do outro, onde então estaríamos no campo do sadismo, ou de outro, cuja finalidade é a recuperação narcísica através de um ato violento. Encontramos também em Jurandir Costa (2003), argumentação apoiada na teoria das pulsões, distinguindo os conceitos de necessidade e desejo, onde a necessidade é aquilo que atende ao instinto e portanto tem objeto definido, e o desejo é o que permeia a pulsão, característica do humano. Define a violência, assim como Corsi, como um ato associado a um desejo, portanto um ato significado. Esse é um aspecto interessante na medida em que, ao pensarmos que a violencia não tem objeto fixo, esse pode ser substituido ou se valer de representantes substitutivos. Essa não fixidez se presta a que a violência ou o sentido atribuido a ela, possa ligar-se a qualquer representante cultural. Desta forma, a valorização cultural de um certo ideal de masculinidade, pode ser o objeto do desejo a ser recuperado através do ato.
} 
los hombres con los que se encontraron no respondían al estereotipo construido pos el imaginario colectivo y sustentado por algunos modelos teóricos. Los hombres violentos no eran los 'pobres, borrachos y enfermos', sino que se los encontraba en cualquier sector social y educativo... (1995, p.5).

É fato que atos violentos podem ser encontrados em qualquer segmento da população, assim como é fato que tais atos podem ser praticados tanto por conhecidos como por desconhecidos. Contudo, não podemos deixar de considerar dados que nos são disponibilizados por pesquisas (como a do Noos), que indicam que, na incidência desses atos, verifica-se uma prevalência maior associada à baixa escolaridade, assim como há maior prevalência de atos violentos praticados por homens conhecidos, com algum vínculo com a mulher do que por homens desconhecidos (SCHREIBER, L. \& D'OLIVEIRA, A. F. P. L., 2000- 2001).

\subsection{DE QUAIS HOMENS FALAMOS?}

Considerando, portanto, a discussão acima colocada, não podemos simplesmente falar em grupo de homens, sem localizar a que grupo nos referimos, isto é, que tipo de inserção social têm, quais os códigos que compartilham (se é que compartilham), sua origem, grau de escolaridade, raça, religião, faixa etária, etc. Um outro aspecto não abordado em nenhum dos estudos até aqui verificados, mas que nos parece fundamental é o grau de desenvolvimento e de recursos psíquico-emocionais que lhes garantam uma flexibilidade mental, viabilizando o questionamento de valores e posições adotadas. Observamos em nosso trabalho que homens com menor grau de escolaridade tendem a aderir de forma mais rígida às prescrições de uma masculinidade hegemônica tradicional. Este 
também é um dado observado na já mencionada pesquisa realizada no Rio de Janeiro por Acosta e Barker (2003) com homens de diferentes extratos sociais.

Contudo, como já ressaltamos no capítulo 3, ainda que seja possível fazermos tal associação, há um certo número de homens que, embora tenham baixa escolaridade, apresentam ainda assim recursos psíquicos mais desenvolvidos que lhes permitem um grau de flexibilidade em suas concepções, ou uma abertura em relação a poder ocupar lugares alternativos, que não exclusivamente o seu, de maneira mais marcante do que outros. Este dado sugere que devemos buscar outra variável significativa no desenvolvimento de padrões culturais e pessoais ${ }^{36}$.

A fim de definir o escopo de nosso grupo de trabalho e investigação, é importante que façamos ainda, mais uma ressalva antes de considerá-los num mesmo agrupamento. Em virtude da grave crise econômica do País, que resultou num alto índice de desemprego, houve uma equalização do poder aquisitivo de muitos destes homens, equalização esta que se expressou por uma significativa perda econômica, e que não correspondeu a uma equivalência quanto ao nível de escolaridade e educação formal a que tiveram acesso. Isto posto, podemos fazer um recorte para fins de nosso estudo, dos aspectos mais freqüentemente encontrados na população atendida, uma vez que a PMFC tem como restrição , que o usuário receba como renda máxima, 5 salários mínimos.

\footnotetext{
${ }^{36}$ Embora não seja o escopo deste trabalho, é sem dúvida uma característica que deve ser pensada, a meu ver, do ponto de vista da constituição do sujeito e não unicamente da cultura. Sugiro como possibilidade teórica para pensarmos esse fenômeno, as formulações de Bion (1991), sobre as primeiras relações do bebê com sua mãe, que, sendo capaz de prover ao bebê com a função de reverie, uma função capaz de conter ou acolher dentro de si (ao que Bion chama de 'sonhar') as angústias do pequeno bebe, vai com isso provendo este de condições de construir um aparelho de pensar os pensamentos. Neste processo, vai sendo possível transformar o que chamou de elementos beta - elementos concretos, não passíveis de serem transformados ou sonhados - em elementos alpha, necessários para a condição de sonhar, elaborar pensamentos, e abstrair.
} 
Assim como descrevemos em outra parte, ${ }^{37}$ os homens com os quais trabalhamos pertencem a famílias de baixa renda, em situação de violência intrafamiliar, que se encontram, geralmente, em conflito e sob o impacto de grandes tensões.

Constantemente expostas a ameaças quanto a sua sobrevivência e integridade, essas famílias vivem em estado de marginalidade social, numa condição em que o desejo de respeitabilidade é constantemente contrariado e o afeto densamente sobrecarregado de frustrações. Carentes de educação e informação, discriminadas e desrespeitadas pela sociedade, criaram para si um repertório de soluções compatíveis com os seus parcos recursos. Por todas essas razões, pelas tensões e frustrações mantidas pelas dificuldades materiais básicas, suas relações “matrimoniais” costumam ser pouco estáveis.

A população que hoje procura nossa Instituição é, na sua grande maioria, formada por migrantes ou filhos de migrantes, vindos principalmente do nordeste brasileiro nas décadas de 1970 e 1980, os quais trocaram as zonas rurais em que viviam pelas possibilidades de trabalho e melhoria de vida que a cidade grande podia lhes oferecer. Mesmo tendo ascendido socialmente, em relação às gerações que os precederam nas suas cidades de origem, esta melhoria foi muito relativa. Os problemas de adaptação à cidade grande para famílias extremamente pobres de origem rural, que, não dominavam a leitura e a escrita, foram inúmeros. Concentrados na periferia da cidade, constituíram grupos pouco homogêneos, cuja identidade comum foi a de serem pobres. São pessoas que, tendo baixa ou nenhuma escolaridade, não apresentam qualificação para exercer trabalhos mais elaborados, atuando, portanto, predominantemente, como operários da construção civil, encanadores, motoristas de ônibus, frentistas de postos de gasolina ou ainda, em alguma atividade do

\footnotetext{
37 Amplamente baseado em capítulo publicado em co-autoria com Malvina Muszkat (2003), intitulado Permanência na diversidade: um estudo sobre a conjugalidade nas classes de baixa renda In: GOMES, P. B. (org.). Vínculos Amorosos Contemporâneos: psicodinâmica das novas estruturas familiares. São Paulo: ed. Callis, 2003.
} 
mercado informal. As dificuldades de trabalho e a parca renda familiar refletiram e refletemse ainda hoje, na expectativa frustrada de mobilidade social depositada no estudo dos filhos.

Há razões de sobra para justificar o baixo nível de escolaridade dessas crianças: trabalho ou mendicância, abandono, ausência de adultos que exerçam algum tipo de estímulo sobre sua vida escolar, e, inadequação do ensino público promovendo evasão escolar.

O fenômeno da crescente incorporação de mulheres no mercado de trabalho ${ }^{38}$ não encontrou, principalmente nas classes pobres, qualquer tipo de contrapartida por parte do Estado no que diz respeito à proteção dos seus filhos (dispositivos sociais como creches, centros de lazer, etc). As conseqüências dessa realidade são facilmente constatadas no crescente processo de degradação do bem estar de crianças e adolescentes, criando um movimento de desintegração social de conseqüências alarmantes. Além disso, é evidente, nessas camadas, cujos pais já apresentavam baixa ou nenhuma escolaridade, a perpetuação da defasagem cultural, principalmente quando comparados a outros jovens da mesma idade advindos de classes mais favorecidas. Cronificou-se o baixo nível de competitividade, agravado pela crescente deterioração do ensino público brasileiro.

No que diz respeito às influências no processo de socialização sobre os mais e menos educados, verifica-se a disponibilidade dos mais educados de receberem e aceitarem a ação de especialistas - médicos, psicólogos, pedagogos -, darem prioridade ao parceiro no que diz respeito ao encaminhamento de suas questões, e demandarem, por conseqüência, maiores demonstrações de lealdade dos mesmos. Os menos educados toleram laços maiores de dependência com seus pais, (KOMAROWSKY, 1967) mantendo a família original (especialmente a mãe) como principal fonte de referência cultural e social. A figura materna

\footnotetext{
${ }^{38}$ Não podemos ignorar o fato de que as mulheres da classe pobre, sempre tiveram que 'trabalhar fora' ou para fora de casa, antes mesmo da grande entrada das mulheres no mercado de trabalho, sendo este um fenômeno mais característico das mulheres de classe média.
} 
representa a principal fonte de informação positiva durante toda a vida, e mesmo quando ela é considerada ultrapassada do ponto de vista da sexualidade ou da religião, sua opinião é vital, no que se refere às regras da vida conjugal, tanto para as mulheres como para os homens.

Constatamos, em nossa experiência com os grupos, relatos de vários deles que afirmam não ter com quem conversar sobre questões pessoais, sendo que a pessoa escolhida preferencialmente para esta atividade são suas mães. A estas pedem sugestões e conselhos e recebem orientações sobre como proceder nas questões relativas à vida pessoal e afetiva. As mães da maioria destes homens, além de, interferirem diretamente na vida dos casais, ainda, por motivos econômicos e culturais, freqüentemente compartilham da mesma moradia ou do mesmo quintal.

São, muitas vezes as mães, as responsáveis por levantarem suspeitas quanto à idoneidade de caráter das noras, criticando o modo como estas dirigem suas casas, ou, no caso de coabitarem, impedindo que estas ocupem um lugar de preferência afetiva junto aos maridos (seus filhos). Ainda outro dado significativo é o fato de que são também elas quem normalmente se encarregam da criação dos netos, desempenhando assim a função materna para estas crianças, nos casos em que a guarda legal é concedida ao homem (pai da criança). Exceção a isso se dá quando este homem encontra-se em situação de união estável com outra companheira.

Assim, ideais de masculinidade, nessa classe, orientados pelo modelo hegemônico masculino, provê um ideal de masculinidade que faz de muitos homens pessoas com dificuldade de comunicação. Observamos com freqüência que a possibilidade de falar ou trocar impressões a respeito de questões de âmbito pessoal ou familiar, é uma experiência vetada aos homens. Somente às mulheres é permitido falar sobre estes assuntos, tidos como 
“perigosos” nos círculos masculinos. O sentido do perigo está em abrir a outros suas fragilidades ou dificuldades pessoais, fato este tido como denegridor de sua moral masculina.

\section{3- CONTRIBUIÇÕES PSICANALÍTICAS}

Os estudos relativos às questões de gênero, desde seus primórdios quando do surgimento do movimento feminista nas décadas 60-70, sempre ficaram a cargo dos sociólogos e antropólogos, mais especificamente dos diversos grupos feministas. Com raríssimas exceções (KERNBERG, 1995; CARVALHO, 2003), não encontramos na literatura psicanalítica um interesse pelo tema. Ampliando um pouco o escopo para o plano da violência em geral, encontramos ainda poucos autores do campo psicanalítico dedicados à compreensão destes fenômenos, no que se refere à sua expressão no âmbito social.

Os estudos e a prática psicanalítica, posteriores a Freud, voltaram-se prioritariamente à clínica, privilegiando-se o atendimento a pacientes individuais. Podemos levantar como hipótese para o predomínio desta tendência, o próprio método desenvolvido por Freud, nos primórdios de seus estudos com pacientes histéricas a partir de 1890, no qual objetivava tornar consciente o inconsciente, revelando e dando sentido aos sintomas inicialmente traduzidos por manifestações somáticas.

Essa metodologia, portanto, coadunava-se com um atendimento clínico individual, fundamentalmente voltado para o tratamento das neuroses.

Contudo, as questões sociais nunca foram menosprezadas, nem por Freud, nem por diversos outros autores de contribuição relevante para a teoria psicanalítica, como Winnicott, Klein, e Lacan. 
Encontramos na obra freudiana, importantes trabalhos tais como: Totem e Tabu (1913), Psicologia das Massas e Análise do Ego (1921), O futuro de uma ilusão (1927), O Mal-estar na civilização (1930), Por que a guerra (1933), Novas Conferências Introdutórias (1933), onde o autor desenvolve formulações acerca do funcionamento e modos de organização social, ou seja, descreve a possibilidade de formação da civilização com base em exigências da cultura sobre as forças pulsionais do indivíduo. Vemos, assim, que a preocupação investigativa com as questões do ser humano não se restringiu aos estudos intra-psíquicos individuais, mas estiveram sempre acompanhando a cultura e a sociedade em suas manifestações, nos diversos níveis de inserção humana.

A tradição da prática psicanalítica brasileira priorizou a clínica individual em detrimento do que seu arsenal teórico tem a contribuir, não só para a compreensão dos fenômenos sociais como também para a proposição de formas de ação. No âmbito da violência, embora assistamos às suas manifestações com preocupação e assombro, encontramos esparsas produções psicanalíticas contemporâneas voltadas ao tema.

Neste capítulo, procuraremos acompanhar dentro da obra de Freud, alguns dos trabalhos que consideramos significativos para o entendimento de suas concepções acerca das formas de organização social e processo civilizatório, assim como das expressões de violência por meio da inter-relação das pulsões no interior do aparelho psíquico e no mundo externo (Introdução ao narcisismo, 1914; Além do Princípio do Prazer, 1920; Psicologia das Massas e análise do ego, 1921; O Ego e o Id, 1923; o Mal-estar na Civilização, 1930; Conferência XXXV, 1933). Para tanto, iremos articular concepções tais como desamparo, violência, narcisismo, ideal de ego e superego assim como desenvolvido em seus artigos, bem como em trabalhos de autores contemporâneos, como Carvalho (2003), Khan (2002), Kehl (2005). 
Nossa hipótese é a de que a violência pode ser uma forma de proteção contra a ameaça do desamparo decorrente da perda de traços e marcas identitárias da masculinidade. Trata-se então de examinar, do ponto de vista da metapsicologia freudiana, as relações entre violência, identificação e desamparo.

Ao percorrermos os trabalhos psicanalíticos que tratam de violência, deparamo-nos com uma diversidade de usos e sentidos, que nomeiam as diferentes violências. Identificamos, ainda, contido em todas estas diversas acepções, o conceito de desamparo como fator que se repete.

Procuraremos, portanto, entender a violência e sua relação com o desamparo, com o intuito de verificar se essa relação se sustenta ao pensarmos na violência de gênero. Buscaremos na teoria das pulsões, com seu caráter dualista, fundamentos que nos auxiliem na compreensão e questionamento do dualismo com caráter valorativo (bom/ruim, certo/errado, etc) encontrado na cultura, aprisionando os indivíduos em organizações mentais rígidas.

\subsubsection{Identidade e gênero}

Com base no material das 4 sessões apresentado no capítulo 3, pudemos verificar o predomínio de um tipo de fala que expressa um modo de pensar pautado pelos ideais tradicionais de gênero.

O que prevalece é um tipo de compreensão e explicação, sobre os acontecimentos que esses homens vivenciam no âmbito de suas relações interpessoais, que vêm marcadas por um maniqueísmo, no qual identificamos definições pré-formadas acerca dos lugares, 
papéis e funções de homens, mulheres, pais e mães, bem como conceitos pouco flexíveis no que se refere às noções de sexualidade, reprodução, parentalidade, vida conjugal e divisão sexual do trabalho.

Há também uma tendência a atribuir o motivo de suas dificuldades ao outro, sendo assim impedidos de pensarem na implicação deles próprios como sujeitos de suas experiências de vida. Essa dificuldade, que vemos repetidas vezes nos encontros em grupo, leva-os a darem a estas experiências significados bastante parciais: sentem-se, não raro, vítimas ou injustiçados. O mau, a má ação, atribuído ao outro, fica fora, exterior a eles.

O desejo ou orgulho de ocupar este lugar hegemônico, como já destacado por Oliveira (2000), é característico nesta população masculina. Oliveira, ao contestar a idéia de vitimização masculina, contesta a idéia do sofrimento ou prejuízo resultante de um submetimento imposto culturalmente aos homens. Concordo com sua argumentação e sugiro o termo vitimização, como a expressão de um sentimento destes homens, que observamos em suas falas, para descrever uma vivência de perda do lugar, outrora concedido aos homens numa organização hegemônica tradicional. Ressentem-se quanto à perda do que entendem como um privilégio, ou mesmo, um direito natural. Em outras palavras, a injustiça à qual se referem diz respeito à perda de uma identidade, construída social e culturalmente, e que é significada como modelo exclusivo de identidade masculina. Embora seja fato, assim como diz Carvalho (2003, p.27), que

a ideologia igualitária ganhou destaque também no Brasil. As repercussões disso nas relações de gênero têm sido salientadas, por exemplo, na liberdade sexual, maternidade fora do casamento, modificações na maneira como a sociedade pode observar as práticas homoeróticas e nas escolhas amorosas. 
Isso contrasta com as falas dos homens que estudamos, evidenciando que as práticas ou as leis funcionam à margem do imaginário, dos desejos, e do que, portanto, é reproduzido culturalmente. A igualdade existe como idéia, mas a prática da mesma é “questionada ou boicotada” tanto por homens como por mulheres.

Vemos uma ilustração disto na fala a seguir, extraída de um dos encontros: “...minha mulher nunca trabalhou fora de casa, ela começou a trabalhar e agora acha que pode tudo... por causa das brigas e do telefone bati na filha e agora não falam mais comigo". Ainda em outro momento complementa, "O marido serve pra tudo, é o chefe, educa a família, trabalha, cuida da casa...” e conclui explicitando um sentimento de humilhação e pesar, “to muito chateado, construí tudo e é como se tivesse perdido tudo...”. Este homem havia sido obrigado a sair de casa como resultado de uma ação cautelar determinada pelo juiz, após ter batido em sua filha e ter sido feito um boletim de ocorrência do fato. Verificamos, nesse pequeno exemplo, a confusão quanto a sua noção de identidade. Durante muitos anos fora o provedor, chefe de família, e sua mulher trabalhava exclusivamente em casa: a divisão sexual do trabalho dentro do padrão tradicional de gênero lhe proporcionava um reasseguramento quanto à sua noção de identidade masculina. No entanto, acredita que o fato de sua mulher ter começado a trabalhar fora de casa tenha feito com que perdesse seu lugar, sendo este agora tomado por ela. Não dispõe de outros recursos que lhe possibilitem a manutenção de uma noção de si mesmo.

A construção da identidade como aquilo que dá ao ser humano o sentido de sua continuidade no tempo e espaço, que faz com que se reconheça como sujeito singular é um bem precioso do indivíduo em sua luta permanente contra o desamparo fundamental que marca o ser humano, sendo a identificação, processo pelo qual se dá a construção da identidade, segundo Freud (1921) a mais remota expressão de laço ou vínculo emocional com outra pessoa. É fato que, o ser humano sem um vínculo inicial com um outro ser (a mãe 
ou substituto), responsável por seus cuidados, ficaria abandonado ao desamparo e à impossibilidade de desenvolver-se tanto física quanto psiquicamente. É, conseqüentemente, na relação de intersubjetividade - portanto com um outro - que se dá a construção da identidade do sujeito, sendo também importante destacar que sem a relação com este outro, não haveria sujeito. Conforme nos relembra Freire Costa (2003), a teoria psicanalítica postula a fundação do psiquismo humano como algo possível somente na inter-relação com o desejo do outro. A linguagem, veículo de transmissão do desejo e impregnada pela cultura, é condição para a constituição do psiquismo (idem, p.21). Assim, não só se torna impossível dissociar a constituição psíquica da noção de cultura, como também fica evidente a incongruência em pensarmos, em se falando do humano, num caráter de naturalidade (dado naturalmente) como explicação para os modos de funcionamento do indivíduo social.

A luta contra a ameaça do desamparo e de vivências de fragilidade e impotência equivale, metapsicologicamente falando, à necessidade de manutenção de uma integridade narcísica. André Green (1988), psicanalista francês contemporâneo, diz acerca de um tipo de resistência à mudança que encontra na clínica psicanalítica:

Uma das principais razões desta oposição tenaz, quando a análise recai sobre o Eu, é o narcisismo. O cimento que mantém a unidade constituída do Eu reuniu seus componentes para adquirir uma identidade formal tão preciosa ao sentimento de sua existência quanto o sentido pelo qual ele se apreende como ser. Deste modo, o narcisismo opõe uma das mais ferrenhas resistências à analise (p.9).

Embora não estejamos, neste trabalho, abordando aspectos da clínica psicanalítica, penso ser possível a aplicação desta compreensão ao que observamos nos homens. A adesão destes homens a determinados padrões de ideal de masculinidade é justificada se entendermos que o abalo narcísico, decorrente de uma não-adesão, implicaria num risco de perda do sentido de existência ou de identidade, quando este sentido se encontra atrelado a tais padrões ideais. 
Essa afirmação nos remete ao que amiúde observamos em nossa amostra masculina, expressa como uma resistência em abrir mão de determinados lugares identitários, sob o risco de se encontrarem sem apoios identitários, ou, ainda, ficarem mergulhados naquilo que denominamos desamparo identitário.

Kehl (1996) define o que chamou de 'produção da identidade', como “artifício protetor de nossa solidão subjetiva diante do enigma do desejo” (idem, p.12) como motor da pulsão - incessante e poderosa - e em permanente busca de um objeto de satisfação. Freud (1905), já sabemos, postula o objeto da pulsão como objeto variável, não definido e portanto nunca definitivo. Essa formulação, por si, marca o eterno desamparo do ser humano, fadado a jamais encontrar (já que inexistente), ou melhor, a jamais re-encontrar o objeto da plena gratificação, propiciador do sentimento de plenitude, baseado na vivência narcísica originária de onipotência e plenitude vivida com a mãe (ou representante responsável pelo bebê). O objeto da gratificação será assim, sempre provisório e em última instância, frustrante. Sobre o objeto frustrante, Freud (1915) dirá em Instintos e suas vicissitudes, que, sendo este causador de desprazer ao ego, desperta-lhe ódio levando-o a querer destruir o objeto. Em Freud, como afirma neste mesmo trabalho, a relação de ódio é anterior à de amor, uma vez que, antes de mais nada, em seus primórdios, o ego visa a proteger-se da vivência de aniquilamento. Em outras palavras, a agressividade ou a violência são manifestações que têm, como finalidade máxima, a preservação do ego. A questão que vale salientar aqui é que, ao falar de amor ou ódio, o que de fato está em jogo é o anseio pela manutenção da integridade egóica. O ego 'odeia’ o que lhe ameaça a integridade e 'ama' o que lhe recupera ou garante a mesma. Esta idéia é também amplamente discutida em seu artigo de 1914, Sobre o Narcisismo, ao descrever os mecanismos utilizados pelo ego como forma de manutenção do narcisismo, ou ainda, de forma mais coloquial, de amor-próprio. Este é, a meu ver, um ponto essencial para os propósitos deste trabalho, uma vez que viabiliza distinguirmos diferentes manifestações de 
violência. Deste prisma, o ato violento praticado, tem como finalidade principal, a preservação narcísica do ego, sendo a destruição do outro conseqüência e não o objetivo que leva ao ato. Mais uma vez desejo ressaltar, que esta colocação de forma alguma se presta a justificar atos violentos, nem tampouco negar o caráter de destruição e prejuízo que estes atos

implicam para o outro. É, contudo, fundamental, para os propósitos desta dissertação, que caracterizemos de forma mais precisa as distintas motivações que dão origem ao ato violento a fim de que possamos dispor de recursos na lida com tais mecanismos. Dentre as várias denominações de violência, desejamos, neste trabalho, ocuparmo-nos em distinguir três delas: a violência de gênero, a violência fundamental, assim como descrita por Isabel Kahn Marin (2002) e, por último, a violência como prática resultante da desfusão pulsional, que implica uma ação independente do sadismo cujo caráter de pulsão destrutiva visa à obtenção de prazer libidinal.

\subsubsection{O Princípio do Prazer e a violência de gênero}

Em Introdução ao narcisismo (1914, p.102), Freud diz, "reconhecemos nosso aparelho mental como sendo acima de tudo um dispositivo destinado a dominar as excitações que de outra forma seriam sentidas como aflitivas ou teriam efeito patogênicos”. Como já dissemos anteriormente, a conceituação formulada por Freud sobre as vivências de prazer e desprazer, é construída como um modelo econômico, no qual o desprazer se relaciona a um acúmulo de tensão no interior do aparelho mental. Prazer, portanto, para o ego é o que não é sentido como desprazer, ou seja, não se dá como resposta a uma presença satisfatória, mas como resultado da eliminação ou afastamento do desprazer, que ocorre quando há um aumento de excitações. Tomando esse postulado, já desenvolvido por Freud em 1911 em seu, Formulações sobre os dois princípios do funcionamento mental, como ponto de partida para nossa elaboração, procuraremos argumentar quais os fatores que do ponto de vista das 
relações de gênero, representam um acúmulo desprazeroso ao aparelho mental e as soluções adotadas que visam a livrar-se desta vivência de desprazer.

Freud inicia o referido artigo (1911, p.277, grifo nosso) dizendo que, “Os neuróticos afastam-se da realidade por achá-la insuportável, seja no todo ou em parte” e continua, “defrontamo-nos com a tarefa de investigar o desenvolvimento da relação dos neuróticos $e$ da humanidade em geral com a realidade”. Explica que o funcionamento sob o Princípio do Prazer, associa-se ao modo mais antigo e primitivo do aparelho psíquico, regidos pelos processos primários. Estes se caracterizam, em oposição aos processos secundários, por seu conteúdo inconsciente, não sujeito aos princípios da lógica que regem a realidade e o pensamento consciente. Assim, estando submetido a um desejo ou necessidade o aparelho mental encontraria, num primeiro momento, via uma solução alucinada, atender ao desejo a fim de eliminar o acúmulo de tensão gerada.

Neste tipo de solução, destacamos duas características fundamentais: seu caráter primitivo e a solução instantânea (já que alucinada), não admitindo um espaço entre o surgimento do desejo (tensão) e sua realização (via alucinação).

Destaco essas duas características em razão de sua semelhança de funcionamento com o comportamento que observamos nos homens de nossa amostra. A resposta imediata, não mediatizada por pensamentos que não os dos ideais hegemônicos, que visa a eliminar a frustração, o desprazer ou a ameaça quanto à manutenção da identidade, reproduz o sistema de funcionamento mental apoiado no princípio prazer/desprazer. Desta forma, esse modelo, por sua característica dualista, nos parece interessante como instrumento para a compreensão do modo predominantemente dualista e maniqueísta de funcionamento que verificamos nas falas dos homens de nossa amostra.

Posteriormente, segundo Freud (1911), no que representaria uma etapa de maior desenvolvimento do aparelho mental, é introduzido um novo sistema, o Princípio da 
Realidade, que tem como característica a possibilidade de o aparelho psíquico tolerar, por um tempo maior, o estado de tensão, efetuando uma transformação na realidade que possa atender ao desejo não mais de forma alucinada. Este espaço criado entre o surgimento da necessidade e a nova ação, admite então a entrada do pensamento, regido pelos processos secundários (da lógica e do contato com a realidade), garantindo assim uma eliminação mais eficiente e duradoura do desprazer. Freud esclarece que um organismo que insista em viver de acordo com o princípio do prazer “deve possuir dispositivos que o capacitem a afastar-se dos estímulos da realidade”, e mais, “trata os estímulos desagradáveis internos como se fossem externos- ou seja, empurra-os para o mundo externo” (idem, p.279). Embora, nesta passagem, não dê a esse mecanismo o nome de projeção, descreve o que assistimos com freqüência nos relatos das sessões, quando o sentimento de frustração e impotência leva estes homens, em inúmeras ocasiões, a atribuírem às mulheres o motivo de sua vivência desprazerosa.

Observamos uma naturalização dos direitos do homem sobre os destinos da mulher, sua companheira, bem como uma crença instituída quanto às diferenças hierárquicas de poder. Isso é por eles compreendido como algo natural, isto é, da natureza dos homens e das mulheres. Constatamos ainda este caráter na maneira como são atribuídos sentidos à sexualidade masculina e feminina e às noções de atividade e passividade ${ }^{39}$. Nossa expectativa com o trabalho grupal é o de promover, através das atividades e dos questionamentos propostos, uma ampliação de sentidos e a construção de um repertório mais vasto de significados, de forma análoga ao que Freud descreve no processo de passagem do Princípio

\footnotetext{
${ }^{39}$ A este respeito, e apoiado nos Três Ensaios sobre a Sexualidade (1905), Carvalho (2003) faz um importante esclarecimento das teorias freudianas concernentes às noções de atividade e passividade pulsionais. Diz ele: "Freud aponta para a importância de não superpor termos, nem considerar aspectos como atividade ou passividade como sendo destinos do homem ou da mulher. A distinção é essencial pois contribui para que ao discutirmos a subordinação feminina, construída nas relações hierárquicas de gêneros, atreladas às noções de superioridade e inferioridade, não entendamos que tais posições dizem respeito à tendência pré-determinada de um ou outro sexo " (grifo nosso, p.43). Este não é de forma alguma um detalhe sem importância, uma vez que Freud é freqüentemente acusado como um pensador que, tendo influenciado o pensamento e a cultura em geral, teria também contribuído em ditar padrões patologizantes e normatizantes às diferentes práticas sexuais.
} 
do Prazer para o Princípio da Realidade. Neste último, torna-se possível a interposição do pensamento à ação agressiva imediata, sendo esta imediatez resultado de uma atribuição restrita de sentidos à experiência, representando uma ameaça à manutenção de uma identidade masculina.

\subsubsection{O narcisismo e o ideal do ego: a cultura na constituição da subjetividade}

No artigo sobre narcisismo (1914), Freud deixa clara a vinculação entre o desejo, por parte do indivíduo, pela manutenção de seu narcisismo - entendido como a representação de uma vivência mítica originária na vida do bebê, de plenitude, onipotência, numa experiência de amor fusional vivida com a mãe -, e os mecanismos que o ego desenvolverá para a recuperação desta situação narcísica. A este momento inicial e mítico de experiência do ego denomina-o ego ideal ${ }^{40}$. No processo de desenvolvimento, o ego, a fim de manter-se íntegro, deverá reprimir seus impulsos edípicos e agressivos, aceitando as imposições da cultura, o que implicará a renúncia ao ego ideal. A repressão pulsional, exercida por mecanismos que provêm do próprio ego, tem como finalidade a proteção deste, e é o resultado do que Freud denominou de amor-próprio do ego. O ego ‘percebe’ os riscos ao qual estará submetido caso rejeite as imposições da cultura, ou seja, o risco da castração, da perda do amor que ameaça sua integridade ${ }^{41}$. Paradoxalmente, é preciso que o sujeito abra mão deste narcisismo originário a fim de manter sua integridade narcísica. Desta forma, o ser humano deve

\footnotetext{
${ }^{40}$ Uma descrição pormenorizada da diferença entre ego ideal e ideal do ego, assim como formulada por Freud e discutida por Garcia-Roza, encontra-se no trabalho de Carvalho (p. 64-65; 2003).

${ }^{41} \mathrm{O}$ temor à castração como o marco que leva o sujeito à entrada na cultura, representa a condição da incompletude humana. Assim, a renúncia ao ego ideal, à plenitude fálica, promove por um lado a entrada na cultura, e a promessa futura de ser recompensado através da adesão a valores culturais, levando o sujeito agora a não mais buscar alcançar o ego ideal- perdido para sempre- mas sim seu equivalente social, o ideal do ego. É importante a ressalva de que a busca em atingir-se o ideal do ego a fim de 'livrar-se' da castração, é o engano a que o ser humano está fadado a viver, uma vez que a castração, a incompletude, a fragilidade são próprias da condição humana, podendo ser apenas provisoriamente afastadas, mas nunca definitivamente eliminadas, gerando uma eterna busca pelo ideal do ego fantasiado. Embora essa idéia possa ser fonte de desalento, é também o que permite pensarmos em processos de transformação do sujeito da cultura.
} 
renunciar à sua completude narcísica e, ao fazê-lo, passará a realizar uma busca incessante a fim de recuperar seu narcisismo perdido.

O ideal do ego, é assim o substituto do narcisismo perdido da infância, diz Freud (1914), postulando a criação de “um agente psíquico especial (futuramente, em 1921, denominado superego), que realizará a tarefa de assegurar a satisfação narcísica proveniente do ideal do ego, medindo o ego real por aquele” (idem, p.112). Esclarece ainda que, “o ideal do ego desvenda um importante panorama para a compreensão da psicologia de grupo. Além de seu aspecto individual, esse ideal tem seu aspecto social; constitui também o ideal comum de uma família, uma classe, uma nação” (idem, p.119), dando-nos importantes subsídios para a compreensão da relevância dos ideais culturais sobre os padrões de comportamento de distintos grupos. A construção da identidade, resultante da interação do sujeito inicialmente com o ambiente familiar - permeada pela cultura - e posteriormente com o grupo cultural no qual está inserido, se dá com a introjeção das interdições e valores transmitidos por estes dois grupos. Freud ainda adverte que a separação do ideal do ego, a partir do ego, impõe a este último um esforço considerável nesta busca de equiparar o ego a este ideal, afirmando que "há sempre uma sensação de triunfo quando algo no ego coincide com o ideal do ego" (idem, p.166). A partir disto, deduz-se que a distância experimentada entre o ego e seu ideal de ego, é vivida como fracasso e sentimento de inferioridade, o que muitas vezes observamos no universo de nossa amostra, ao por exemplo, serem confrontados com sua impotência real ante as demandas que lhes são impostas com base num referencial hegemônico de masculinidade (ser o provedor, ser o chefe da casa, ter o controle sobre mulher e filhos).

Assim como o ideal do ego diz respeito ao ego, a idealização diz respeito ao objeto, que é engrandecido às custas da libido narcísica do ego, que, ao realizar este processo, se enfraquece. Podemos observar a maneira como isso se dá pelas falas dos participantes de um 
dos grupos ao descreverem o que pensam sobre a figura do pai. Ouçamos novamente a definição de um desses homens: “O pai é tudo. É Deus”.

Esta afirmação é complementada por outras, atendendo a um pedido meu sobre o que achavam ser a função de um pai do ponto de vista do filho. Anoto o que dizem: "O pai serve para alimentar, dar carinho, brincar, conversar, dar atenção, sair juntos”.

A certa altura, dois outros participantes, relembram o fato de já estarem trabalhando aos oito anos de idade, retirando assim o caráter idealizado por meio do qual a figura paterna vinha sendo descrita e evidenciando uma realidade menos fantasiosa quanto aos 'poderes' do pai em relação aos filhos. Vemos aí a contradição entre o pai-deus-tudo, idealizado, e a real condição de um pai que não tem meios de manter os filhos, ou que não está presente, impondo ao filho que trabalhe tão precocemente. Verificamos como aquilo que não tem inscrição como experiência real é vivido no plano idealizado e preenchido com roteiros préestabelecidos. Vale notar que as respostas sobre o que é ser pai, não raro são vagas ou esparsas, denotando assim uma falta de idéias a respeito do universo que ocupam como pais, maridos e filhos. As respostas mais comuns são: “para sustentar a família ou trabalhar, para ensinar o que é certo ou errado para os filhos, para manter a ordem na casa e na família”. Por vezes, ao falarem do tema, ainda do ponto de vista deles como filhos, afirmam a importância da companhia do pai nas brincadeiras, ou, então, destacam a importância do pai para 'ensinar coisas’ para o filho. O afeto e a intimidade, experiências construídas no cotidiano familiar, não se constituem como registro no mundo emocional da maioria destes homens, quanto às funções de pai e de marido.

É comum ouvirmos, o relato orgulhoso daqueles que 'nunca deixaram faltar nada à família', referindo-se exclusivamente ao sustento econômico da mesma, à guisa de expressão afetiva. Da mesma forma, constatamos que, ao se verem impossibilitados de pagarem pensão alimentícia a seus filhos, sentem-se humilhados, acreditando não terem quaisquer direitos 
sobre os filhos, nem mesmo o de acesso às visitas. Com isso, muitas vezes afastam-se, reforçando assim o sentimento de isolamento e desvalorização a que ficam submetidos, tanto filhos quanto pais. Relacionamentos em que predominam a distância e a escassez de contato, combinados com os valores disseminados por uma cultura hegemônica quanto aos papéis e funções de pais e mães, têm como resultante a atribuição idealizada dos lugares parentais, assim como vimos no relato acima. A idealização, como bem sabemos, é o reverso do sentimento de persecutoriedade (conhecido disparador de atos violentos), tendo como conseqüência inevitável, o sentimento de baixa auto-estima.

Também é freqüente se sentirem ofendidos e raivosos quando suas ex-companheiras procuram, regulamentar (via homologação judicial) a pensão alimentícia dos filhos: “Não precisava nada disso! Ir na justiça pra quê? Sempre que eu posso eu dou tudo que eles precisam! Mas agora essa, eu fiquei com raiva mesmo”.

Entendem isto como um ato que depõe contra sua idoneidade moral e dignidade, atributos altamente valorizados num universo de exclusão social como o que vivem e no qual dispõem de tão poucas qualificações. Ser chamado a comparecer a algum órgão da Justiça é, não raro, visto como ‘coisa para bandido’.

Nos casos em que as mães impedem a visita dos pais a seus filhos, predomina o sentimento de pesar e ódio pelo afastamento. Constatamos que a rigidez dos papéis em que homens são meramente provedores e mulheres são as responsáveis exclusivas pela vida doméstica - onde se inclui a criação dos filhos- promove um abismo na comunicação e nos afetos, produzindo ressentimentos para ambos os lados, bem como uma sobrecarga de tarefas muitas vezes impossíveis de serem preenchidas, resultando em ódio, frustração e sentimentos de baixa auto-estima para todos. Portanto, verificamos que a idealização e a manutenção do sentimento de poder se dá às custas de uma negação de parte da realidade que vivem. A possibilidade de manter-se o ideal de ego e a ocupação de um lugar idealizado de poder são 
muitas vezes alcançados tendo em vista o apoio da companheira, de forma complementar. Contudo, uma vez que a mulher recusa este lugar, exigindo que o homem proveja aquilo para o qual está impossibilitado, desvela a condição real e não, a ideal. A sustentação da cultura hegemônica de gênero se dá, portanto, desde que se perpetuem os acordos inconscientes entre ambas as partes envolvidas, homens e mulheres.

\subsubsection{Violência e civilização}

Como vimos até aqui, podemos constatar uma inter-relação entre desamparo, ódio e agressividade/violência, uma vez que estes últimos ocorrem como resposta a vivências de desamparo, condição inerente ao humano. Se o desamparo é condição humana, devemos entender que a agressividade também o é, já que encontram-se interligados. De fato, encontramos no magnífico trabalho sociológico de Freud (1929), O mal-estar na civilização, afirmação quanto ao caráter naturalmente mau, agressivo e abusivo presente no ser humano, que, se manifestaria contra seus semelhantes, não fosse pelo processo imposto pela civilização, que, em troca de garantir-lhe a segurança contra a vivência de desamparo, exigelhe que renuncie a uma grande parcela de seus impulsos agressivos e destrutivos. ${ }^{42}$ Ainda assim, verificamos que esta renúncia é parcial, sendo que os grupos (sociais, familiares, de gênero, de raças, etc) representam uma forma de organização social que atende ao mesmo tempo à necessidade de contenção do impulso agressivo (que então se manifesta contra outros grupos), como também garante o cuidado e proteção no interior de um mesmo grupo, onde todos se tornam semelhantes, por meio de um processo de identificação. Freud (1929) atribuiu a esta hostilidade contra o diferente (mas não muito diferente, como faz questão de

\footnotetext{
${ }^{42}$ Em Totem e Tabu (1913), Freud elabora uma construção mítica acerca da fundação da civilização, na qual, a partir do assassinato do pai da horda primitiva, os irmãos a fim de garantirem sua própria sobrevivência não sendo também assassinados como o pai, criam a primeira lei (o tabu do Totem), sob a qual, de comum acordo, ficam impedidos de expressarem livremente seus impulsos sexuais e agressivos. Em Mal-estar na civilização, Freud afirma, "o homem civilizado trocou uma parcela de suas possibilidades de felicidade por uma parcela de segurança” (1929, p.137).
} 
ressaltar), a já bastante conhecida denominação de narcisismo das pequenas diferenças. Em suas palavras, “é sempre possível unir um considerável número de pessoas no amor, enquanto sobrarem outras pessoas para receberem as manifestações de sua agressividade” (idem, p.136).

Kehl (1996), a esse respeito, faz uma crítica de como em nossa sociedade contemporânea, a necessidade de manutenção das identidades e o temor de vê-las ameaçadas, leva a práticas violentas. Em sua definição,

as identidades são as próteses subjetivas produzidas na sociedade de massa- e quem vive no século XX, em qualquer período, sabe que a afirmação das diferenças, constituídas como formação de grupos identitários, tem tido antes o efeito de produzir a intolerância do que o diálogo e a convivência na diversidade (idem, p. 12).

Mas se a condição de existência ou sobrevivência da civilização, como afirma Freud, depende da contenção da agressividade, quais serão os meios através dos quais isso será possível? O que fará com que o ser humano renuncie ao seu impulso agressivo submetendose às imposições da civilização? Freud responde a isso referindo o temor ao desamparo e a condição de dependência como fatores determinantes para esta renúncia. O medo da perda do amor, diz ele, somado à noção do indivíduo de sua própria fragilidade e falta de autonomia, faz com que, por temor a ser abandonado e ver-se sujeito a inúmeros riscos, o indivíduo aceite a introdução do que em última instância podemos entender como a introdução da cultura, da lei. (1929, p.147) Laplanche e Pontalis (1983), definindo a concepção freudiana de desamparo, ressaltam o aspecto econômico deste estado, caracterizado por um acréscimo de tensão cujo aparelho se vê impedido de dominar. Assim, “no quadro da teoria da angústia, o estado de desamparo torna-se o protótipo da situação traumática” (idem, p.157). É ainda, por caracterizar-se como um estado de total dependência do outro, e em sua relação com uma mãe onipotente, que o desamparo "determina de forma 
decisiva a estruturação do psiquismo, voltado a constituir-se inteiramente na relação com outrem” (idem, ibidem). A condição de prematuridade do ser humano em relação a outros animais, determina, dizem eles citando Freud, que "a influência do mundo exterior é reforçada, a diferenciação entre o ego e o id é necessária, a importância dos perigos do mundo exterior é exagerada e o objeto que é o único que pode proteger contra estes perigos e substituir a vida intra-uterina, vê seu valor enormemente aumentado. Este fator biológico estabelece pois as primeiras situações de perigo e cria a necessidade de ser amado, que nunca mais abandonará o homem” (idem, ibidem). Khan Marin (2002), baseando-se na concepção Lacaniana do desamparo como significante na história do sujeito, diz,

É a partir desta condição de depender de um Outro por sua condição de "falta de ser" (manque à-être) que irá atendê-lo e situá-lo na ordem social, da cultura, que o sujeito se constitui num parlêtre ("ser que fala”), ou seja, a simbolização é fundamental para o enfrentamento do desamparo e da constituição subjetiva (idem, p.137).

É nesta relação com o outro que o indivíduo constrói a sua subjetividade e adquire condições de simbolização, que, como sabemos, se dá a partir da falta. Sem esta condição, o sujeito "se vê mercê de suas forças pulsionais, estando assim exposto a um excesso de excitação” e um sentimento de abandono (idem, ibidem). É neste sentido que Kahn irá argumentar a favor da necessidade da violência fundamental, como ato de contensão pulsional e possibilidade de entrada na cultura. Se o desamparo é definido como a exposição egóica ao descontrole psíquico, a castração remete à idéia da perda de um objeto valorizado. Segundo Laplanche e Pontalis (1983) uma das características teóricas do complexo de castração "é o seu ponto de impacto sobre o narcisismo: o falo é considerado pela criança uma parte essencial da imagem do ego; a ameaça que lhe diz respeito põe em perigo, de forma radical, essa imagem” (idem, p.112). O complexo de castração tem sua formulação inicial em 1908, referindo-se à diferenciação sexual da presença ou ausência do pênis (idem, 
p.111). Posteriormente terá assegurado seu "lugar fundamental na compreensão da evolução da sexualidade infantil e sua articulação com o Complexo de Édipo” (idem, p.112). Freud descreve em O mal-estar na civilização (1929), o superego, como a instância psíquica que doravante será responsável por supervisionar o ego, comparando-o sempre ao ideal do ego a fim de realizar a aproximação entre estes. Herdeiro do complexo de Édipo, o superego é resultado da introjeção das prescrições parentais, às quais a criança se submete a fim de garantir a permanência do amor destes por ela. Desta forma, é, a um só tempo, a expressão da submissão do indivíduo à condição de ‘castrado’, uma vez que submeteu-se à repressão de seus impulsos edípicos hostis e amorosos, bem como a saída possível para evitar-se a castração, garantindo o amor parental e tendo como promessa futura a recuperação narcísica por meio do ideal do ego. A introdução da lei civilizatória, embora implique uma renúncia, é paradoxalmente o que garante ao indivíduo proteção e sua inserção na condição de humanidade. Se na infância, o superego representa a introjeção das ordens parentais, na vida adulta, estas são substituídas pelas ‘ordens da cultura', o que faz com que siga submetendo-se aos códigos vigentes em dada cultura. Dito de outra forma podemos de modo análogo, entender que a impossibilidade de cumprir/atender às exigências do superego cultural, desperte temores ligados à vivência de castração, de incompletude ou de desamparo. Desta forma, o risco de perda da identidade masculina, caso não atendam aos ideais de masculinidade pregados pela cultura hegemônica, representa uma ameaça de castração, resultando num abalo do equilíbrio narcísico. Vemos aí a estreita associação entre superego, ideal do ego, desamparo e castração.

É deste prisma, considerando a introdução da cultura como forma imprescindível de corte pulsional, que Isabel Kahn (2002), em seu livro Violências, desenvolve sua tese. A concepção acerca do que se denomina como violência simbólica, é bastante familiar no universo psicanalítico sendo compartilhada por autores tais como Piera Aulagnier, Ferenczi, 
Laplanche e outros, referindo-se, como explica Jurandir Costa (2003), à idéia de uma violência primordial exercida sobre a criança ao dotar de sentido as experiências vividas por ela, com base no vértice do adulto cuidador. Assim, a qualificação dos sentidos do mundo social, é dada pelo outro (outro aqui com o sentido de um não-eu) e nesse sentido, arbitrária. É este caráter arbitrário o que é significado como violência. Desta forma, se por um lado a violência deve ser reprimida ou sublimada para garantir-se a manutenção da civilização, é também, paradoxalmente, através do ato violento que se dará a constituição do sujeito como sujeito da civilização.

Com base no que foi desenvolvido até aqui, fica clara a relevância, sob a ótica psicanalítica, das implicações da agressividade (como são normalmente designadas as expressões de hostilidade nos textos freudianos $)^{43}$, com a constituição do sujeito, a construção de sua identidade, as defesas do ego contra vivências de aniquilamento e desamparo e a manutenção da ordem social humana com base na construção dos laços sociais de proteção.

Obviamente, como cidadãos da cultura sabemos que a violência é algo bastante presente, sendo a violência de gênero uma de suas formas de expressão que nos inspirou a realizar este trabalho.

Sendo a violência entendida tanto como ato destrutivo (que age contra o outro ou contra o próprio sujeito), como ato fundante - assim como descrito em Totem e Tabuprocurarei, valendo-me do referencial psicanalítico e baseando-me amplamente no trabalho de Kahn, que se volta à esta questão, discutir em que medida a problemática da violência de gênero converge ou diverge da violência descrita pela autora, como resultado do desamparo pulsional, procurando identificar as especificidades deste tipo de violência que se dá como expressão das relações de gênero.

\footnotetext{
${ }^{43}$ Remeto o leitor ao capítulo 2 do já citado livro de Isabel Kahn Marin (2002) para uma interessante digressão a respeito do uso do temo violência ao longo da obra de Freud.
} 
Kahn, encontra na teorização de Piera Aulagnier, fundamentação importante no que descreve ser o "paradoxo trabalhado por Freud do jogo entre as pulsões, marcando o lugar do adulto (social) na constituição do sujeito e lançando alternativas para se pensar na possibilidade criativa de amansamento das pulsões da violência” (KAHN, 2002, p.30). Sustenta a tese de que nossa sociedade contemporânea tem como característica o predomínio de um funcionamento narcisista onde o sujeito é regido por sua satisfação pessoal e imediata em detrimento de valores éticos e morais, garantidores de uma organização social (idem, p.17). Denuncia, a partir de sua observação institucional e clínica, o fato de que embora muito se fale acerca da preocupação com a violência no mundo atual, não verifica nos indivíduo em geral (refere-se aos adultos cuidadores), a disponibilidade em assumir qualquer lugar associado a ela. Desta forma, declara a dificuldade em assumir-se a função paterna ou o lugar da lei, identificando o que denomina de “predomínio da ideologia do amor” (idem, p.19), que ao contrário de promover um bem estar em crianças institucionalizadas com as quais trabalhou, impedia-as de entrarem em contato com suas reais vivências e histórias pessoais de sofrimento, não podendo assim, realizarem o luto simbólico necessário. Percorrendo os trabalhos de Freud, identifica esta tendência de negação da violência como "um movimento da humanidade, ao longo da história, em que o homem busca recuperar um momento de estabilidade para sempre perdido, onde não havia nem dor nem necessidade de representação -o estado nirvânico” (idem, p.27). O estado nirvânico foi usado por Freud pela primeira vez em 1920 para definir o objetivo da Pulsão de Morte, cujo intuito é levar o aparelho mental ao menor estado de excitação possível, daí a referência ao nirvânico ${ }^{44}$. Com efeito, tal estado de suposto prazer e ausência de violência é paradoxalmente a expressão purificada da Pulsão de Morte ou da destruição. Desta forma, a recusa em romper, cortar, proibir -mecanismos contrários àquele da Pulsão de Vida, que visa acumular e unir - numa

\footnotetext{
${ }^{44}$ No apêndice de As Neuropsicoses de defesa (1894), encontramos a referência à primeira citação de Freud ao 'princípio do Nirvana', feita em 1920 no trabalho Além do Princípio do Prazer.
} 
fantasiosa pretensão de eliminar a violência e o desprazer, é, se seguirmos o raciocínio de Freud, não só impeditivo da organização social e da introdução do sujeito na cultura, como também um movimento que o levaria a morte.

Depreendemos do trabalho de Kahn sua formulação acerca da necessidade do exercício de uma certa violência, a fim de se dar conta da violência pulsional a que o sujeito estaria submetido, especialmente no início da vida, a fim de que se possa adentrar a ordem do humano (idem, p.31). Assim, a autora denomina de violência fundamental a violência necessária à produção do corte pulsional e à atribuição arbitrária de sentidos imposta pelo adulto à criança, como descrita por Piera Aulagnier em sua definição de violência primária. Sobre o risco que a negação da violência em nossa cultura apresenta, diz

\begin{abstract}
a questão que se coloca, portanto, é como a partir da negação da violência, que pode ser justamente reveladora da própria, facilitar que o sujeito consiga entrar em contato com o que isso está expressando, que afetos estão evolvidos, o que representam, para que possa encontrar meios socialmente aceitáveis de expressá-los (idem, p.46).
\end{abstract}

Sabemos, como também é descrito por Kahn, que o excesso de excitação provoca desprazer e pode reativar o desamparo (idem, ibidem), sendo que a impossibilidade da realização do corte pulsional, através da violência fundamental, justificada por uma ideologia do amor, ou, como também denominado por ela, sob o predomínio do Princípio do Ego Ideal ou Império do Narcisismo, abandona o sujeito a vivências intoleráveis de intensidade pulsional, vividas como trauma, uma vez que não encontram meios de escoamento. Essa intensidade levaria ao ato violento aniquilador do outro, como forma de aliviar-se desta intensidade. O desamparo e o estado de vazio, com conseqüente impossibilidade de construção de uma identidade neste cenário, teriam no ato violento, destruidor do outro, uma forma de expressão última da singularidade do sujeito. 
Encontro neste ponto a necessidade de fazer uma primeira diferenciação entre este tipo de violência e a violência de gênero. Sem dúvida, pelo que expus até aqui, podemos entender o ato de violência praticado por certos homens como um recurso que visa ao resgate e à afirmação de sua identidade masculina. Certa vez, um participante de um dos grupos me disse: “às vezes, não é que o homem quer bater na mulher, mas ele tem que bater para mostrar para os outros homens que ele é quem manda na casa”. A garantia do olhar que confirma, um olhar que, como espelho, lhe reflete a imagem desejada é o que impulsiona este ato. É possível, ainda, fazermos uma analogia com a violência por intensidade pulsional, no que esta tem de recurso último de expressão da singularidade, de um resgate de identidade, por meio de uma tentativa, ainda que precária e destrutiva, de sentir-se tendo um lugar no mundo. Do ponto de vista do que temos observado em relação à violência praticada por grupos de jovens que não encontram lugar de inclusão na esfera social, isso faz sentido, uma vez que este ato lhes outorga um lugar de singularidade, lhes confere uma identidade que antes não havia. Contudo, se este tipo de violência vem marcada, como diz Kahn, pelo predomínio da fantasia do Ego Ideal, que, como dissemos, é regida por um narcisismo onipotente sem a mediação das interdições da cultura, a violência de gênero é, por sua vez, regida pela busca do Ideal de Ego, cuja marca é sua associação com os valores culturais que substituiriam o primeiro modelo, sendo assim um ideal construído a partir da entrada na cultura. A violência de gênero, como a entendo, se por um lado é resultado de um desequilíbrio interno por falta de referencial e sentimento de afastamento do ideal de ego, ainda assim não tem o mesmo sentido da violência resultante da intensidade pulsional que visa a evitar o aniquilamento do ego.

É fator relevante que uma cultura, cujos valores são pouco flexíveis, é também propiciadora do tipo de desamparo ao qual chamei de desamparo identitário na medida em que a possibilidade de se alcançar estes ideais torna-se uma exigência psíquica intensa e de 
resultados pouco criativos no âmbito das relações interpessoais. Nesse sentido, penso a violência de gênero como um ato voltado a uma demanda de reconhecimento de sua hegemonia, de recuperação de uma identidade idealizada, e não de um ato que visa à ‘formatação’ de uma identidade, como é a violência aniquiladora que descreve Kahn. Sendo assim, na violência de gênero, o outro se torna imprescindível como ‘espelho’ que lhe restitui o lugar desejado, lhe resgata o ideal de ego.

\subsubsection{O desamparo, o mundo contemporâneo e a sociedade}

Kahn descreve o que entende como sendo a marca da diferença entre o que denomina de sociedades tradicionais e a sociedade moderna. Citando Lasch, diz: “O indivíduo da sociedade moderna é livre para escolher seu destino, paixões, e deve construir sua identidade. É a sociedade onde o Eu domina e que vai caracterizar a cultura do narcisismo” (LASCH, 1983 apud KAHN, 2002, p. 50). Essa descrição, de uma sociedade que parece valorizar e voltar-se completamente para o indivíduo, é também a de uma sociedade que o deixa sem contornos, sem lugar, numa vivência de abandono e desamparo.

Penso que não seria adequado caracterizar a população com a qual trabalho como regida por este abandono no sentido caracterizado pela ‘liberdade’ de construção da própria identidade, da forma descrita por Lasch. Como temos visto, muito ao contrário disto, estes homens parecem ter a identidade já previamente definida, de forma bastante fixa, sendo a sua luta a de adequar-se ou equiparar-se a este ideal de masculinidade. Há, no entanto, um outro tipo de abandono ao qual estão relegados: o abandono de sua condição de cidadãos de direito pelo Estado. Se não podemos dizer que esta amostra caracteriza o homem pós-moderno, globalizado, criador de si mesmo, tampouco podemos pensar que não sejam permeáveis aos valores de consumo e de mercado que regem nossa sociedade atual. Ainda como resultado desta ideologia narcisista, assistimos a uma desmoralização da função paterna e dos valores 
que representam a palavra do pai. Paradoxalmente, observamos que esta população é regida por valores em que predominam, no universo imaginário, os ideais patriarcais, nos quais, como sabemos, são demarcadas hierarquias, contornos, lugares determinados, que são também lugares identitários. Assim também são suas relações e suas aspirações de trabalho, sendo freqüente ouvirmos relatos de como preferem ter empregos que, embora bastante insuficientes do ponto de vista de garantir-lhes o lugar de provedor patriarcal, ainda, assim, lhes assegura como cidadãos de bem, uma vez que têm carteira assinada, registro, e a condição de ser um empregado, ao contrário da condição de autônomo, com ganhos variáveis, normalmente referida por eles como um estado de desemprego. A esta desmoralização do pai na sociedade contemporânea, soma-se, o que Maria Rita Kehl (em comunicação oral, 2005) descreve como uma situação mais enfraquecida diante da ideologia de Estado dominante, pautada pelas leis de mercado e não pelo cuidado com seus cidadãos. Sujeitos desta violência social, na qual não têm assegurado seu lugar de cidadãos, impossibilitados de prover os seus, dada sua condição de precariedade de recursos materiais e sociais, e tendo seu valor confundido com seu poder de compra/consumo, estes homens devem 'criar' recursos para driblar a condição de humilhação a que se encontram submetidos, sendo estes, muitas vezes, o abandono de seus filhos e o comportamento agressivo contra suas companheiras, que lhes ‘espelham’ não o lugar valorizado, mas este lugar de precariedade. Assim, no trabalho em grupo que desenvolvo com eles, procuro fornecer subsídios que lhes ampliem o sentido de valor pessoal, sem que este esteja vinculado ao valor financeiro de que dispõem. Algumas conversas que tivemos, por exemplo, giravam em torno de irmos enumerando possibilidades de programas com seus filhos que não dependessem de dispêndio de dinheiro, como jogar bola, ir ao parque, e alguns sugeriam programas gratuitos oferecidos na cidade, enfim, atividades em que o privilégio recaísse nas relações pessoais e não nos bens adquiridos para os filhos nos dias de visitas. 
Não desejo de forma alguma idealizar o trabalho com o grupo de homens, mas destacar situações que observo com razoável freqüência, como resultado dos encontros, que são de estabelecer-se entre os participantes um sentimento de solidariedade, amparo e reconhecimento de sua condição (seja ela de raiva, de dor ou de impotência), ou até mesmo de respeitosa discordância diante de situações que consideram criticáveis, favorecendo o sentimento de resgate de dignidade e respeitabilidade. Ao final de uma reunião, que era a última da qual ele participava, um dos homens disse a todos “aqui aprendi que também tenho direitos”.

\subsubsection{O sadismo e a violência de gênero}

Não desejo negar, nem tampouco diminuir, as conseqüências que penso serem perniciosas tanto às relações entre homens e mulheres, como àquelas que se dão no interior das famílias, e, mais ainda, no que representam como modelo violento de relacionamento, reproduzido quando da constituição de novas organizações familiares, em que prevalecem formas desiguais de poder, sob a forma de violência de gênero. Sabemos, e as estatísticas estão aí para confirmar, que a violência praticada por homens contra mulheres é dado de significativa relevância, levando mulheres a todo tipo de opressão, que se manifestam em variados sintomas clínicos, em casos de depressão, chegando até mesmo em casos de morte.

Contudo, embora seja uma discriminação bastante tênue de se fazer, penso que atos de violência praticados por alguns homens, sob a forma de espancamento, tortura e humilhação sistemáticos, não caracterizam o tipo de violência de gênero a que me refiro, sendo, a meu ver, expressão do que Freud caracterizou como sadismo. Lemos em Além do Princípio do Prazer (1920, p.74):

Desde o início identificamos a presença de um componente sádico no instinto sexual. Como sabemos, ele pode tornar-se independente e, sob a 
forma de perversão, dominar toda a atividade sexual de um indivíduo. Surge também como um instinto componente predominante numa das 'organizações pré-genitais', como as denominei. Mas como pode o instinto sádico, cujo intuito é prejudicar o objeto, derivar de Eros, o conservador da vida? Não é plausível imaginar que esse sadismo seja realmente um instinto de morte que, sob a influência da libido narcisista, foi expulso do ego e, conseqüentemente, só surgiu em relação ao objeto?

O que Freud propõe é que tenha ocorrido uma desfusão das pulsões de forma que a corrente destrutiva passa a agir de maneira independente, não podendo ser atenuada por Eros, com sua força de ligação. Ao longo da obra de Freud, como já mencionado neste trabalho, vemos que a teoria dos instintos que, em 1920 resultará na formulação das Pulsões de Vida e de Morte, tem caráter dualista.

Freud irá descrever o movimento característico de cada uma das pulsões (já referido neste trabalho), sendo a união e ligação características da Pulsão de Vida, e o corte, a destruição, o retorno a um estado anterior de coisas que tende a um estado nirvânico, característicos da Pulsão de Morte. Retomando a articulação proposta por Kahn, sobre a necessidade de exercer-se uma violência fundamental, podemos depreender que a desfusão, ou a ação isolada de qualquer uma das pulsões, teria efeito destrutivo, seja voltado ao interior do aparelho mental, seja voltado ao exterior como ato destrutivo do outro. A não interrupção, através de uma violência fundamental, da intensidade pulsional, baseada numa premissa de agir sem violência, atendendo narcisisticamente às demandas do sujeito, ao contrário de aplacar a inquietação e intensidades pulsionais, levaria, como vemos descrito pela autora, ao ato violento e destrutivo do outro, como forma de evitar o aniquilamento do próprio ego. A exclusividade da Pulsão de Vida é, portanto, tão destrutiva e insuportável quanto a exclusividade de ação da Pulsão de Morte, que, ao voltar-se para fora, se expressa como sadismo.

Retomando o que propunha acima, sugiro pensar que - embora não possamos fazer uma linha divisória nítida -, atos de violência que evidenciam características de crueldade 
apóiam-se nas relações socialmente autorizadas de desigualdade de poderes entre homens e mulheres, mas devem, no entanto, ser entendidas como manifestações que considero da esfera da patologia e não, como expressão da naturalização das atribuições de masculino e feminino construídos na cultura, assim como definido pelos estudos de gênero. É evidente que a desigualdade de poderes está presente em ambas as formas de relação violenta, e também é evidente que há nas relações hegemônicas de gênero, a intenção (ainda que inconsciente) em manter-se esta desigualdade em favor do homem. Entendo, contudo, que há que se considerar uma distinção bastante essencial: o ato violento, resultado da ação da pulsão sádica, está a serviço da satisfação libidinal, de um prazer obtido no ato destrutivo ou violento, ao passo que a violência ditada pelas relações de gênero, está a serviço da manutenção de uma identidade masculina idealizada, ou, como denominei, é resultado do seu desamparo identitário.

\subsection{AFINAL... POR QUE OS GRUPOS?}

Para finalizar este trabalho, escolhi usar as próprias falas de alguns dos homens de nossa amostra, reproduzindo aqui trechos extraídos de uma entrevista coletiva realizada pela equipe de pesquisadoras, com participantes que haviam completado a seqüência das 4 sessões de grupo. O motivo desta escolha deveu-se a minha convicção de que suas falas, como principais atores, fossem mais significativas do que qualquer elaboração teórica final que pudesse ser feita sobre a vivência e o aproveitamento obtido nos grupos. Este grupo focal teve como finalidade avaliar a eficácia de nossa metodologia institucional (a qual incluiu tanto os grupos aqui estudados como todo o processo de atendimento da instituição), a eficácia dos técnicos, e especialmente procurar identificar, através da entrevista com os participantes, em que medida estas atividades haviam implicado algum tipo de transformação nos padrões de 
relacionamento destes homens. Participaram deste encontro 5 dos homens que também estão nas sessões relatadas no capítulo 3. São eles: A, B, C, D e H. Chamarei a pesquisadora de P.

Como já dito anteriormente, optei por reproduzir apenas alguns pedaços da entrevista total, acreditando que a reprodução integral seria, além de muito longa, pouco relevante para nossa discussão. Assim, excluí a maioria das falas da pesquisadora, bem como as explicações sobre o funcionamento e a finalidade do grupo, que esclareci acima.

$\mathbf{P}$-“Como é que tá sendo essa experiência para o problema que vocês estão trazendo”? D - "Pra mim tá sendo uma experiência muito boa, eu não tinha orientação nenhuma, inclusive essa menina que a gente tem lá, eu registrei porque não tinha orientação nenhuma; se eu tivesse orientação na época, eu não tinha registrado sem fazer DNA e nem nada.

$\mathbf{P}$ - Você veio pra fazer exame de DNA”?

D -“É. E também o DNA e porque a pensão ta atrasada, que na época eu paguei pessoalmente, só que a gente não assinou nada, eu pagava em dinheiro pessoalmente, só que ela quer me comer dinheiro de novo. É isso o que eu quero provar que eu paguei, só que não existe recibo, e na época, se eu tivesse orientação que nem eu tenho agora, eu não tinha registrado. Porque na época eu já fui sem advogado e sem nada, você sabe, o juiz chega, ou então você tem que resolver ali naquela hora, eu achei melhor eu registrar, to pagando pensão desde essa época. O mês que eu troquei de firma, não troquei de emprego, só que troquei de firma, só que ai eu fiquei pagando ela pessoalmente, e ela ta querendo receber os atrasados, e no caso aí a própria oficial de justiça que foi levar a intimação pra mim, eu tinha três dias, ela me orientou pra mim vir aqui”.

$\mathbf{P}$ - “E você encontrou respostas pras suas dúvidas, pra resolver a questão da pensão”? D - “Encontrei, o pessoal (refere-se a seus conhecidos) falou 'assim você vai ser preso', eu tinha medo". 
D -“... mas é o que eu falei aqui, mas acontece que eu não to fugindo da minha responsabilidade”.

D - "Mas se não fosse a orientação aqui, eu tava pondo aquilo na cabeça que eu ia preso mesmo, entendeu? Eu tinha três dias”.

$\mathbf{P}$ - “E ai você conseguiu orientação”?

D-“Não, agora eu to dormindo sossegado e tudo”.

Este é um trecho interessante, pois representa uma situação paradigmática que se repete com uma razoável freqüência na população que nos procura. Vemos que há, por parte destes homens, uma desinformação sobre seus direitos e deveres, ficando à mercê das informações de ‘colegas’, já que dispõem de parco acesso a informações de cunho legal. É comum que sejam processados judicialmente pelas mães de seus filhos, sem que tenham qualquer conhecimento prévio de tal processo, evidenciando a inexistência de qualquer vínculo com a criança ou sua mãe que não seja aquele imposto pela lei, via pagamento de pensão. Não raro constatamos que o pagamento da pensão é vivido como uma pena, castigo, ou entendido como uma atitude mal intencionada da mãe da criança, como na fala "só que ela quer me comer dinheiro de novo". Ainda na fala, "inclusive essa menina que a gente tem lá, eu registrei porque não tinha orientação nenhuma se eu tivesse orientação na época eu não tinha registrado sem fazer DNA e nem nada", identificamos como o registro da criança deveu-se ao que ele acredita ser aquilo que lhe obriga a lei, de forma bastante dissociada da criança propriamente dita. Seu desejo de que fique claro que 'cumpre com suas responsabilidades’ não diz respeito às possíveis necessidades da criança ou sua implicação na geração dela, mas antes se refere a querer garantir sua noção de respeitabilidade como cidadão. A função da Instituição, do ponto de vista jurídico, não é a de liberá-lo de suas obrigações, mas de informá-lo, orientá-lo e garantir-lhe uma representação legal (através da presença de um advogado) perante o juiz, uma vez que ele, como muitos dos homens que 
procuram a PMFC em casos de direito de família, tem seus casos julgados sem o auxílio de um advogado. Esta prática é bastante intimidadora para estes homens que não dispõem de informações de cunho jurídico, sendo com freqüência determinado pelo juiz um ‘acordo’ com o qual eles não têm como discordar, gerando maior distanciamento e ressentimento destes pais em relação às crianças e às mães destas, levando-nos a questionar em que medida as práticas do sistema jurídico contribuem para a manutenção de um sistema no qual aos homens fica reservado o lugar de devedor e culpado e às mulheres, o de vítima. Tanto num caso como no outro - o de culpado ou de vítima -, a responsabilidade do que vai mal é sempre atribuída a um outro 'perseguidor', excluindo ou eximindo o sujeito de despertar em si a noção de sua implicação como um agente de seu destino.

$\mathbf{P}$ - “E o $\boldsymbol{A}$, o $\boldsymbol{B}$, o $\boldsymbol{H}$, o que acham disso”?

D - "Só mais uma coisinha. A minha mulher em casa ela disse, tá me sentido assim, ela disse que eu to assim diferente” (risos).

A -“ Quer dizer que tudo sobrecarrega a gente, é uma tensão muito grande assim”.

D - “Parece que eu tenho mais diálogo assim”.

B - "É porque aqui é grupo de homens, se abrem bastante um com o outro, um falando com o outro, o outro acaba se abrindo, ai você acaba falando. Pô coisas que eu deveria fazer em casa, você não acaba fazendo, e tem muitas pessoas que fazem e tem muitas pessoas iguais ou pior a mim”.

D -“ Porque a minha mulher é legal nessa parte, eu tive um caso entendeu? Com a minha mulher dentro de casa, se a gente não tivesse um diálogo, talvez eu não tivesse em casa, a gente já tinha se separado”.

A - "A gente vem aqui por um objetivo, eu procurei, eu tinha uma audiência marcada, de repente adiou essa audiência, eu prometi fazer essa experiência (procurar a Instituição) e pra mim foi bom. Porque pra mim foi bom, eu nunca tinha passado por uma experiência dessa, eu 
nunca passei por uma situação dessa, de repente você cai na real da lei, porque teoricamente é uma coisa, na prática é outra. Eu ajo assim muito pela...Eu acho a realidade, o dia-a - dia, a coerência. Eu penso assim, a lei às vezes ela é meio falha, eu falo. Caramba, porque ta me acusando disso, se eu não mereço isso, sabe? Então justiça dos homens, justiça de Deus, eu ultimamente eu tenho acreditado na justiça de Deus mais do que na justiça dos homens, então agora eu to lutando para que a justiça seja dos homens. Eu vim aqui, porque aqui o que todo mundo conversa, tudo o que a gente conversa é com um amigo e com outro, e todo mundo ta vivendo o dia a dia. De repente a gente fala. Puta é tão fácil não é? Mas não é, é na teoria, na teoria é uma coisa mais na prática é outra. De repente a gente vem aqui, a gente conversa, de repente acontece da gente vê um vídeo e a gente vê que tem que conversar um pouquinho mais, porque com a pessoa que a gente convive a gente conversa mais de repente a gente não quer mostrar tudo o que a gente tem dentro da gente. Então a gente acaba não se entregando por um orgulho tão bobo, que seria bem mais fácil resolver tantas coisas e não resolve por causa de um orgulho, seria mais fácil”.

As falas acima explicitam algo que, a meu ver, merece destaque, ou seja, estes homens vêm procurar a Instituição por um motivo- o jurídico- e encontram na atividade em grupo algo novo: ouvirem uns aos outros, refletirem sobre suas vidas e as de outros, o que lhes possibilita uma recontextualização de seu lugar no universo familiar e social a que pertencem, experimentando o que foi denominado por Nelson da Silva Júnior como a 'abertura ao questionamento crítico’.

Minha intenção neste trabalho é a de propor algo que vá na direção contrária do que é normalmente proposto pelas tradicionais políticas vigentes e dos rígidos códigos de gênero aos quais se encontram submetidos, que os aprisionam num tipo de narrativa totalitária e normativa. Em outras palavras, o que se pretende é que não haja apenas um discurso oficial e 
autorizado, mas que no discurso de cada um haja também espaço para o discurso alheio, distinto, promovendo-se reflexão e mudanças de posicionamento. A experiência em grupo auxilia o sujeito a criar um espaço psíquico onde a vivência do desamparo não seja algo intolerável, já que compartilhado por outros, criando-se uma espécie de fraternidade entre os participantes. Desta forma, podem tolerar a aproximação com este sentimento, sem terem que excluí-lo ou negá-lo de seu universo de experiências, abrindo-se, assim, um espaço para a reflexão. Poder pensar sobre a ação, o processo ou a experiência vivida, tem repercussões sobre o próprio processo vivido, ampliando o espaço de alternativas quanto às soluções de seus problemas e viabilizando a reformulação de alguns paradigmas habitualmente adotados. Continuando, $\mathbf{P}$ - “E como é que você chegou aqui”?

A - “Não, eu vim pra cá de repente eu conversei, o que que eu precisava?, eu não tinha condições e eu precisava de uma assistência gratuita eu fui atrás porque ela ta com advogado. Eu fui parar na PUC, me deram uma relação, vai pra tal lugar, eu fui procurando e pelos endereços que eu tinha eu vim parar aqui. Me assistiram, eu fiz a entrevista, fiz a triagem vim participar dos grupos, participar dos grupos é importante, é importante porque é o que a gente ta falando. A gente conversa, conversa de bar entendeu?(querendo dizer que na instituição podem ter outro tipo de conversa e que fora de lá a conversa que têm é a de bar).Conversa com pessoas que não tem experiência e não é a teoria, a teoria é uma, a prática é outra, você começa a se abrir um pouquinho mas você cai na realidade.

$\mathbf{P}$ - E conversa de bar rola essas conversas também, esses desabafos”?

C - "Rola. Mas não rola tudo. É um desabafo porque você quer conversar, mas você não fala tudo, e quando você fala alguma coisa a mais. Oh! Você é um corno, você é um chifrudo. Falando português claro. Você é um corno você é um chifrudo”. D- “Não rola por causa disso, qualquer coisinha que você fala você é uma coisa...” 
$\mathbf{P}$ - “É como se você tivesse mostrando uma fraqueza....?”

D - “Isso".

$\mathbf{H}$ - "Se você vai abrir o que rola com você"?

D - “Jogam piadinha”.

H - “É, vai jogar piadinha, e se jogar piadinha, eu não vou gostar, então já dá...”

D - “Dá confusão”.

H - “Dá confusão, se não der morte”.

$\mathbf{P}$ - “E o B, não ouvimos você ainda, como é que foi pra você vir aqui e participar dessas atividades”?

B - “Tem uma amiga minha, eu estava na casa dela e ela estava me contando que tinha participado da casa, e foi conversando com ela que ela falou que era legal e tudo o mais que eu jamais pensei que eu também ia precisar. Eu não pensei que ia ser tão rápido e sem correria. No fim, os assuntos não saem com falatórios, aqui da até vontade de chorar entendeu? Porque é muita emoção. Aqui cada um tem um problema, ninguém tem vergonha conta, e você não tem medo de piadinha, ninguém vai olhar pra você atravessado, não, aqui é dialogo mesmo, aqui é o maior legal. Eu liguei pra cá minha amiga me deu o telefone, a Carol (assistente social), não primeiro eu liguei ela já tinha ido embora era meio dia, porque eu trabalho a noite eu acordei tarde e quando eu liguei ela já tinha ido embora. Então você liga que antes do meio dia ela ta aqui, no outro dia eu liguei, a Carol já marcou a entrevista, mas foi rápido, na mesma semana assim, ela falou pra mim vir na $6^{a}$ feira ela falou que ia montar um grupo de triagem. Eu falei, 'sem problema. To ai toda $6^{a}$ feira, o dia que for eu to ai to vindo', e aqui é legal, tem várias idéias, a sua cabeça começa a ficar completamente diferente. E depois você olha pra trás assim e fala. Não é nada daquilo. Eu não comentei nada com ninguém assim, eu falei que to passando por uma clínica..”.

D - “Por uma clínica? É bom mesmo". 
H - “Lá na empresa é muita gente, vão querer tipo zombar de mim, eu já sei...”

D - “É verdade”.

$\mathbf{P}$ - “Tem preconceito”?

D -“Tem preconceito”.

B - “Eu contei só pra família, só pra mãe”.

H - "No dia que eu falei 'vou no Pro Mulher', os caras já vierem com piadinha. PróMulher, virou mulherzinha agora é? Eles falaram Pró- Mulher? E eu falei, Pró-Mulher é uma instituição”.

Neste pequeno trecho de conversa, vemos com clareza a situação paradoxal em que se encontram, nas falas de $\mathbf{B}$, “no fim, os assuntos não saem com falatórios, aqui da até vontade de chorar entendeu? Porque é muita emoção", e de H, "Pró-Mulher, virou mulherzinha agora é?” Nestas duas falas podemos verificar tanto a necessidade e o prazer em serem legitimamente ouvidos e não desmoralizados por seu sofrimento, como também vemos o temor e a preocupação com a exposição de suas fragilidades e seus problemas. Ouvimos deles que, ao serem flagrados em situação de vulnerabilidade, ficam sujeitos à ridicularização e humilhação por parte de outros homens. A resposta que vem associada a isto é a da violência “confusão, se não der morte...”.

Embora se sintam ouvidos, compreendidos e acolhidos ao experimentarem um modelo alternativo de relacionamento interpessoal (o atendimento pelo serviço social, o trabalho e discussão em grupo), verificamos que este sistema de trocas, autorizado às mulheres, é vetado ao universo masculino. Associam fragilidades e sofrimentos pessoais ao que é atributo feminino. Sendo assim, expressões de solidariedade masculina, no ambiente de conversa mais convencional, como nas chamadas 'conversas de bar', expõem tanto o ator quanto seu interlocutor solidário ao risco de verem-se classificados como 'fraco’, não viril, distanciado do homem-macho-potente. Tal qual o que lemos nas falas acima, a exposição dos sentimentos 
íntimos, desperta, naquele que ouve, o temor em ver-se identificado com aquele que fala (uma vez que pode ‘encontrar-se’ com suas próprias vivências dolorosas e não potentes), afastandoo dos padrões desejáveis de masculinidade, e levando-os muitas vezes a comentários de ridicularização ou desvalorização através de falas como: “você é corno, é um chifrudo...”. Ficam vetadas as conversas mais íntimas, a possibilidade de obterem amparo para a dor, sendo estas freqüentemente transformadas e expressas através de falas ou atos violentos. Um círculo vicioso se estabelece, inviabilizando a criação de canais de comunicação alternativos. A precariedade de recursos emocionais, aliada a uma restrita gama de significação das experiências emocionais (homem traído, por exemplo = corno= homem desvalorizado), nos auxilia a compreender a desarticulação verificada nas conversas de muitos homens.

$\mathbf{P}$ - "Você falou da questão das ofensas, dos xingamentos, são formas também de ofensas que vão se construindo..."

H - “Vão”.

$\mathbf{P}$ - “E às vezes elas culminam, muitas vezes chega num ponto de agressão física de ambos os lados, então era preciso trabalhar com os dois lados. Daí a intenção, o interesse da PróMulher também em desenvolver a questão da mediação, de tentar através de alguns conflitos, preparar as pessoas para que elas possam conversar sobre aqueles problemas, e tentar achar uma solução, tentar achar um acordo. Não é toda violência que é possível mediar, não é toda situação de violência, às vezes existem casos mais graves que precisam de outro tipo de atendimento, de tratamento, não é? Mas os conflitos fazem parte do nosso dia-a-dia e a gente pode aprender a lidar com eles..”.

A - "Pode, pode.

P- "Aí o $\mathbf{D}$ estava falando que a mulher dele estava falando que ele estava diferente em casa..”.

A- “Mas é porque dá uma aliviada, dá um apoio, não é”? 
D - “Não, porque antes pra contar essa situação do problema meu, eu quase não se abria dentro de casa sobre esse lado de cá, entendeu? Agora não. Eu chego lá, eu explico pra ela como é a situação, o que foi rolado aqui. Eu falei. É engraçado, quando eu falava dessa mulher, aí você achavas ruim: Não, mas agora eu tenho orientação como que é as coisas, entendeu? Antes não. Antes pra mim, quando eu via a menina, essa mulher ligava lá pra casa e falava que eu tive lá e que fui me encontrar com ela, aí já virava aquele conflito”.

Aqui verificamos que se amplia a noção daquilo que pode ser caracterizado como um comportamento violento, retirando-se o caráter 'natural' de algumas formas de comunicação. Reconhece-se o valor agressivo de determinados comportamentos, uma vez que a vivência correspondente, ou seja, o sentido dado a determinadas experiências é o de ser agredido ou de estar agredindo. Também há um aprendizado que possibilita o participante a conversar com sua mulher. Abrem-se novas trilhas nas pautas de relacionamento. Essa é uma das metas do grupo: abrir novas possibilidades de pensar-se uma situação. O que antes lhes era vetado e causava vergonha, ou ainda o que era sentido como motivo de provocação, pode ser significado de forma diferente, gerando novos modos de relacionamento nos padrões de gênero.

Assim como vimos descrito no trabalho de Carvalho (2003) em relação a uma tendência idealizadora e de apego a valores de um amor romântico em mulheres, diante de situações de maior desamparo (contaminadas por HIV), ou de menor condição de significação alternativa, vemos de forma análoga, nos homens de nossa amostra, que situações de desamparo, fragilidade e vulnerabilidade, os levam a se ‘ampararem’ através da adoção de valores tradicionais de masculinidade hegemônica, assim como definido pelos estudos de gênero, sendo uma de suas manifestações prevalentes o uso de alguma forma de violência. Em ambos os casos, assistimos a uma estereotipia como último recurso simbólico. 
Poderem falar sem serem alvo de 'piadinhas', compartilhar de suas experiências de vida para as quais não têm outro tipo de inscrição simbólica, mostrou-se, em alguns casos, propiciador de modificação e produção de novas narrativas, trabalho este característico da escuta e prática psicanalíticas.

Acreditamos, portanto, que é somente por meio da inclusão de ambas as partes, ou ambos os gêneros, que ações transformadoras sejam de fato possíveis. A manutenção de lugares fixos e desiguais para os distintos gêneros, como têm sido as práticas tanto das políticas públicas quanto da cultura de maneira geral, só tenderá a reforçar e perpetuar a desigualdade e a opressão ora de uns, ora de outros, em prejuízo para todos. 


\section{REFERÊNCIAS BIBLIOGRAFICAS}

ADORNO, T; FRENKEL-BRUNSWIK,E; LEVINSON, D. J.; SANFORD, R. N. La Personalidad Autoritaria. Buenos Aires: Ed. Proyección, 1945.

ACOSTA, F. \& BARKER, G. Homens, Violência de Gênero e Saúde Sexual e Reprodutiva: um estudo entre homens no Rio de Janeiro. Rio de Janeiro: Instituto Noos, 2003.

ALVIM, S.F. Violência Conjugal e Alteridade: Estudo Exploratório com Homens e Mulheres Agredidos e Agressores. 2003. Dissertação (Mestrado) - Instituto de Psicologia, Universidade Federal do Espírito Santo, Vitória, 2003.

ARILHA, M.; RIDENTI, S. G. U.; MEDRADO, B. (org.). Homens e Masculinidade: outras palavras. São Paulo: ed. 34, 1998.

BANDEIRA, L. E SUÁREZ, M. A politização da violência contra a mulher e o fortalecimento da cidadania. In: BRUSCHINI, C. \& UNBEHAUM, S. (org.). Gênero, democracia e sociedade brasileira. São Paulo: Fundação Carlos Chagas; ed. 34, 2002.

BARBIERI, $\mathrm{T}$ "Sobre la categoria de Gênero. Uma introducción Teórico-metodológica". In: (coord.) Azeredo $\mathrm{S}$ e Stolcke V. Direitos Reprodutivos. São Paulo: Fundação Carlos Chagas, 1991. (25-47)

BARBOSA, R. M. Um Olhar de Gênero Sobre a Epidemia de Aids. In: BERQUÓ, E. (org.). Sexo e Vida: Panorama da Saúde Reprodutiva no Brasil. Campinas: ed. Unicamp, 2003.

BERQUÓ, E. Arranjos Familiares no Brasil: uma visão demográfica. Vida Privada no Brasil. São Paulo: ed. Companhia das Letras, 1998. in: História da

BION, W. R.. O aprender com a experiência. Rio de Janeiro: Imago, 1991. (Série Analytica).

BOURDIEU, P. (org.). A miséria do mundo. São Paulo: ed. Vozes, 1993.

. Conferência do prêmio Goffman: A dominação masculina revisitada. In: LINS, D. (org.). A Dominação Masculina Revisitada. São Paulo: ed. Papirus, 1998. 
CALEGARE, M. G. A. A transformação social no discurso de uma organização do Terceiro Setor. 2005. 194 f. Dissertação (Mestrado) - Instituto de Psicologia, Universidade de São Paulo, São Paulo, 2005.

CARVALHO, J. A. O amor que rouba os sonhos: Um estudo sobre a exposição feminina ao HIV. São Paulo: ed. Casa do Psicólogo, 2003.

CASTELLS, M. O Poder da Identidade: vol II. São Paulo: ed. Paz e Terra, 2000.

CONNEL, R.W. Masculinities. Berkley and L.A.: University of California Press, 1995.

CORSI, J.; DOHMEN, L.; SOTÉS, M. Violencia masculina en la pareja: una aproximación al diagnóstico y a los modelos de intervención. Buenos Aires: ed. Piadós, 1995.

COSTA, J. F. Violência e Psicanálise. São Paulo: ed. Graal, 2003.

FREUD, S. Obras Completas. Rio de Janeiro: Ed. Imago, 1969.

v. III: As Neuropsicoses de defesa.

v. VII: Três Ensaios sobre a Sexualidade.

v XI: Um tipo especial de escolha de objeto feita por homens (contribuição à psicologia do amor I).

v. XI: Sobre a tendência universal à depreciação na esfera do amor (contribuições à psicologia do amor II).

v. XII: Formulações sobre os dois princípios de funcionamento mental.

v.XIII: Totem e Tabu.

v. XIV Sobre o narcisismo: uma introdução.

v. XVIII: Além do Princípio do Prazer. 
v. XIX: O Ego e o Id.

_v. XXI: O mal-estar na civilização.

v. XXII: Novas conferências introdutórias.

v. XVIII Psicologia das massas e análise do ego.

v. XXII: Por que a Guerra?

v.XIV : O Instinto e suas Vicissitudes

v.XIV: Luto e Melancolia

GIFFIN, K. Violências de gênero, sexualidade e saúde. Caderno de Saúde Pública. Rio de Janeiro, nº 10 (suplemento 1), pp.146-55, 1994.

GREEN, A. Narcisismo de Vida, Narcisismo de morte. São Paulo: ed. Escuta, 1988.

GREGORI, M. F. Cenas e Queixas: Um estudo sobre mulheres, relações violentas e a prática feminista. Rio de Janeiro: ed. Paz e Terra; Anpocs, 1993.

Prefácio. In: MUSZKAT, M. (org.). Mediação de Conflitos: pacificando e prevenindo a violência. São Paulo: ed. Summus, 2003.

HEILBORN, M. L. (org.). Sexualidade: o olhar das ciências sociais. Rio de Janeiro: ed. Jorge Zahar, 1999.

HURST, D. Understanding and Engaging Indigenous Men in Violence Prevention. Conferência proferida em Sidney, Austrália, 2003.

KAUFMAN, M. Las Experiencias Contradictorias del Poder entre los Hombres. In: VALDÉS, T. \& OLVARRÍA, J. Masculinidades: poder y crisis. Chile: ed. Isis internacional: Flacso, 1997. pgs. 63-81. (Ediciones de las Mujeres n²4). 1994. 
(1999). The 7 P's of Men's Violence. Conferência proferida em Toronto, Canadá, 1998, como projeto conjunto da UNICEF e UNIFEM. Disponível em: $<$ www.michaelkaufman.com/articles/7ps.html>. Acessado em: 14/08/03

. The Aim Framework: addressing and involving men and boys to promote gender equality and end gender discrimination and violence, documento preparado sob contrato com a UNICEF. 2003

KEHL, M. R. A Mínima Diferença: masculino e feminino na cultura. Rio de Janeiro: Imago, 1996.

. Comunicação oral na livraria Pulsional, em São Paulo, em 30/03/05.

KERNBERG, O. Psicopatologia das relações amorosas. Porto Alegre: Ed. Artes Médicas, 1995.

KIMMEL, M.S (1994). Homofobia, Temor, Vergüenza y Silencio em la Identitad Masculina. In: VALDÉS, T. \& OLAVARRIA, J. (orgs.). Masculinidades: poder y crisis. Chile, ed. Isis Internacional e Flacso, nº24, 1997. (ediciónes de las mujeres).

KLEIN, M. Notes on Some Schizoid Mechanisms. In: Envy and Gratitude and Other Works. London: ed. Karnac Books, 1946-1963.

KOMAROWSKY, M. Blue-Collar Marriage. USA: Vintage Books Edition, 1967.

LAPLANCHE, J. \& PONTALIS, J.-B. Vocabulário de Psicanálise. São Paulo: ed. Martins Fontes, 1983.

MARIN, I. K. Violências. São Paulo, ed. Escuta: Fapesp, 2002.

MEDRADO, B; ARILHA, M. \& UNBEHAUM, S. (orgs.). Homens e Masculinidades, Outras Palavras. São Paulo: Editora 34, 1998.

MILES, R. Love, sex, death and the making of the male, New York: Summit Books, 1991.

MONTEIRO, M. Sujeito, Gênero e Masculinidade In: BUARQUE DE ALMEIDA, H. et al. Gênero em Matizes. Bragança Paulista: ed. Universidade São Francisco, 2002. 
MUSZKAT, M. \& MUSZKAT, S. Permanência na Diversidade: Um estudo sobre a conjugalidade nas classes de baixa renda. In: GOMES, P. B. (org.). Vínculos Amorosos Contemporâneos: psicodinâmica das novas estruturas familiares. São Paulo: ed. Callis, 2003.

MUSZKAT, M. Guia prático de mediação de conflitos em famílias e organizações, São Paulo: ed. Summus, 2005.

MUSZKAT, S. Novas práticas na abordagem de gênero e violência intrafamiliar. In: MUSZKAT, M. (org.). Mediação de Conflitos: pacificando e prevenindo a violência. São Paulo: ed. Summus, 2003.

OLIVEIRA, M. C.; MUSZKAT, M.; UNBEHAUM, S.; MUSZKAT, S.; BRITO, R. S.; NEVES, S. F. S. Avaliação de um Método de Intervenção no Enfrentamento da Violência Intrafamiliar. Pesquisa realizada pela Unicamp (Nepo)/PróMulher Família e Cidadania, com financiamento da Fapesp e Prosare. 2004.

OLIVEIRA, M. C. F.A.; BILAC, E.D.; MUSZKAT, M. Projeto: Os Homens esses Desconhecidos: Masculinidade e Reprodução. Relatório apresentado à Organização Mundial de Saúde, 2000.

OLIVEIRA, P. P. M. Crises, Valores e Vivências da Masculinidade. Novos Estudos CEBRAP, n 56, pp.89-110, 2000.

A construção social da masculinidade. 2002. Tese (Doutorado) - Faculdade de Filosofia, Letras e Ciências Humanas, Universidade de São Paulo, 2002.

PAIVA, V. Fazendo sexo com camisinha: sexualidades jovens em tempos de aids. São Paulo: ed. Summus, 2000.

Cenas Sexuais, roteiros de gênero e sujeito sexual. In: BARBOSA, R. M. \& PARKER, R. (orgs). Sexualidades pelo avesso: direitos, identidades e poder. Rio de Janeiro: IMS/UERJ: ed. 34, 1999.

PITANGUY, J. Violência de Gênero e Saúde. In: BERQUÓ, E. (org.). Sexo e Vida: Panorama da Saúde Reprodutiva no Brasil. Campinas: ed. Unicamp, 2003.

RAMIREZ, M. C. Do Centro à Periferia: os diversos lugares da reprodução nas teorias de gênero. In: BERQUÓ, E. (org.). Sexo e Vida: Panorama da Saúde Reprodutiva no Brasil. Campinas: ed. Unicamp, 2003. 
ROTHMAN, E. F, BUTCHART, A, CERDA, M. Intervening with Perpetrators of Intimate Partner Violence: A Global Perspective. Geneva: ed. World Health Organization, 2003.

RUBIN, G. Thinking Sex: Notes for a radical theory of the politics of sexuality. In: In: PARKER, R. \& AGGLETON, P. (editors). Culture, Society and Sexuality: a reader. London: UCL/Taylor and Francis, 1999. p. 143-179.

SAFFIOTI, H. Violência Doméstica: questão de polícia e da sociedade. In: Gênero e Cidadania. Mariza Corrêa (org.). Campinas: ed. Pagú; Núcleo de Estudos de GêneroUnicamp, 2001.

SARTI, C. A. A Família como Espelho: Um Estudo Sobre a Moral dos Pobres. São Paulo: Autores Associados, 1996.

SENNET, R. Street and Office: two sources of identity. In: HUTTON, W.;GIDDENS, A. On the Edge: living with Global Capitalism. London: ed. Jonathan Cape, 2000. p.175-190.

SCHREIBER, L. \& d'OLIVEIRA, A. F. P. L. (coord.). Violencia contra a mulher e saúde no Brasil. Genebra: Organização Mundial de Saúde; São Paulo: Departamento de Medicina Preventiva da Faculdade de Medicina da Universidade de São Paulo, 2000-2001.

SCOTT, J. Gênero: uma categoria útil de análise histórica. Revista Educação e Realidade. Porto Alegre, v.20, n², pág. 5-22, jul/dez, 1995.

SILVA JUNIOR, N. Metodologia Psicopatológica e Ética em Psicanálise: o princípio da alteridade hermética. Revista Latinoamericana de Psicopatologia Fundamental. São Paulo, v. 3, n. 2, p. 45-73, 1999.

A sombra da sublimação: o imperialismo da imagem e os destinos pulsionais na contemporaneidade. Revista Psychê. São Paulo, ano VII, nº11, p. 29-38, 2003.

SPINDEL, C.; LEVY, E.; CONNOR, M.. With na End in Sight: Strategies from the UNIFEM Trust Fund to Eliminate Violence Against Women. New York: UNIFEM (United Nations Development Fund for Women, 2000.

SUARÉS, M. Mediación: Conducción de disputas, comunicación e técnicas. Buenos Aires: ed. Paidós, 1996. 
VALDÉS, T. \& OLVARRÍA, J. Introducción. In: Masculinidades: poder y crisis. Chile: ed. Isis internacional: Flacso, 1997. (Ediciones de las Mujeres $\left.n^{\circ} 24\right)$.

VANCE, C. A antropologia redescobre a sexualidade: um comentário teórico. Physis: Revista de Saúde Coletiva. v.5, n 1, pág. 7-29, 1995.

WADDELL, M. (1981). A Família e sua Dinâmica. In: BOX, S. et al. (org.). Psicoterapia com Famílias: Uma Abordagem Psicanalítica. São Paulo: Casa do Psicólogo, 1994. p.2745.

WEEKS, J. (1996). O corpo e a sexualidade. In: O corpo educado: pedagogias da sexualidade. LOURO, G. L. (org.). Belo Horizonte: Autêntica Editora, 2000.

WINNICOTT, D.W. O Brincar e a Realidade. Rio de Janeiro: ed. Imago, 1971.

O preço de se desconsiderar a pesquisa psicanalítica. Palestra proferida na conferência anual da National Association for Mental Health, 1965.

WORLD Health Organization (WHO). World report on violence and health: summary. Geneva, 2002

\section{BIBLIOGRAFIA COMPLEMENTAR}

ADORNO, T. Educação Após Auschwitz: em Palavras e Sinais. Petrópolis: Ed. Vozes, 1995.

ADORNO,T; HORKHEIMER, M. A Dialética do Esclarecimento. Rio de Janeiro: ed. Jorge Zahar, 1985.

ADORNO,T; FRENKEL-BRUNSWIK,E; LEVINSON, D.J; SANFORD,R,N. La Personalidad Autoritária. Ed. Proyección, Buenos Aires, 1945

BIDDULPH, S. Por que os homens são assim? São Paulo: ed. Fundamento, 2003. 
COSTA, G. \& KATZ, G. Dinâmica das Relações Conjugais. Porto Alegre: Artes Médicas, 1992.

CROCHIK, J. L. Preconceito, Indivíduo e Cultura. São Paulo: ed. Robe, 1997.

EIGUER, A. Um Divã para a Família. Porto Alegre: Artes Médicas, 1985.

MACFARLANE, A. História do Casamento e do Amor. São Paulo: Cia das Letras, 1990.

MARCUSE, H. Eros and Civilization: a philosophical inquiry into Freud. Nova York: ed. Vintage book, 1962.

MUSZKAT, S. Uma Nova Versão do Homem com ' $H$ '. Revista Ide da Sociedade Brasileira de Psicanálise de São Paulo. São Paulo, nº 34, 2001.

MUSZKAT, M. Violência de Gênero e Paternidade. In: ARILHA, M.; RIDENTI, S. G. U.; MEDRADO, B. Homens e masculinidades: outras palavras. São Paulo: ECOS/Editora 34, 1998.

SHORTER, E. The making of Modern Family. London: Princeton University, 1976.

WINNICOTT, D.W. Privação e Delinqüência. São Paulo: Livraria Martins Fontes, 1987. 
ANEXO A - Este anexo contém uma breve descrição da situação familiar e dos motivos de procura pela Instituição dos 5 sujeitos que participaram do grupo focal. Este grupo realizouse após o término de 4 encontros consecutivos e visava avaliar a eficácia destas atividades em grupo tanto do ponto de vista do desempenho da coordenação quanto do ponto de vista dos participantes, procurando identificar através de suas falas, se esta atividade gerara algum tipo de impacto em suas vidas e/ou se identificavam alguma modificação em suas concepções acerca de sua condição conjugal/familiar. A participação neste grupo era voluntária. 
Participante $\boldsymbol{A}$ : Veio encaminhado pelo Jecrifam (Juizado especial criminal da família), conveniado com a Instituição, através do projeto de penas alternativas. Este projeto visa tratar de forma alternativa, através de encontros grupais em oposição ao simples pagamento de cestas básicas para o Estado como é habitualmente feito em casos de violência praticada pelo companheiro contra a mulher. O pagamento de cestas básicas não só mostra-se como prática ineficaz do ponto de vista da transformação de comportamentos violentos, como ainda incrementa o risco vivido pela companheira ao ter que voltar para casa com um companheiro humilhado e, não raro, raivoso pelo fato de ter tido que comparecer à presença do Juiz para explicar seu ato. $\boldsymbol{A}$ tem 42 anos, vive em segunda união estável com uma companheira com quem tem 3 filhos adultos, sendo que tem outro filho de uma primeira união. Tendo ameaçado sua mulher e sido violento com esta, foi realizado um Boletim de Ocorrência de agressão por parte desta, cujo resultado foi seu encaminhamento ao Jecrifam. Ele justifica seu ato alegando que a mulher lavava as roupas de um outro homem (supostamente seu amante) e as pendurava em lugar visível para toda a vizinhança ver.

Participante $\boldsymbol{B}: \boldsymbol{B}$ tem 27 anos, é solteiro e viveu em união estável com sua companheira durante 5 anos. Em dois filhos, um de 5 anos de um primeiro relacionamento e outro de 2 com sua segunda companheira. Segundo conta, ele havia viajado com seu filho, e ao retornar sua companheira havia saído de casa e levado todas as suas coisas, tendo ido viver com outro homem que atualmente se encontra preso por roubo. Ao sair, fez um Boletim de Ocorrência de Preservação de Direitos (a fim de resguardar seu direito a bens e não configurar sua saída como abandono de lar e do filho). B procurou a Instituição a fim de pedir a guarda da criança que tem com ela pois alega que a mãe o visita poucas vezes e o filho continuou vivendo com ele desde a saída da mãe.

Participante $C$ : Tem 46 anos, é solteiro e vive em união estável com a terceira companheira. Tem 4 filhos, sendo 2 de sua primeira união, 1 da segunda e 1 da terceira. Sua segunda companheira entrou com uma ação de alimentos contra ele e $\boldsymbol{C}$ chegou à Instituição com prazo de 3 dias para apresentar-se em Audiência perante o Juiz. Alega não ter condições de pagar o que a ex-companheira exige e chegaram a fazer um acordo entre eles onde acertaram um valor de pensão alimentar em troca da retirada da queixa. Contudo a ex-companheira não cumpriu sua parte do acordo, tendo ido embora de São Paulo. Assim, $\boldsymbol{C}$ encontra-se ainda em processo e não podendo encontrar a mãe de seu filho, sua dívida vem se avolumando com o risco de ele ser preso.

Participante $\mathbf{D}$ : Tem 43 anos, 5 filhos de 3 diferentes uniões e procurou a Instituição em razão de uma ação de alimentos movida contra ele por uma das uniões anteriores. Ele alega ter dúvidas a respeito da paternidade desta criança a quem não vê há muitos anos. Alega não ter condições financeiras para pagar o que a ex-companheira pede, já que ganha entre 1 e 3 salários mínimos e tem, atualmente, outra família. Requereu, também, à Instituição, um exame de DNA a fim de certificar-se da paternidade desta criança já que alega ter registrado a criança sem ter certeza de ser realmente seu filho. 
Participante $\boldsymbol{H}$ : Tem 29 anos e é solteiro. Procurou a casa a fim de obter um exame de DNA de uma criança sobre quem tinha dúvidas quanto à paternidade. Conta que sua ex-namorada alegou que o filho que esperava era dele. Ambos foram atendidos na PMFC para a realização do exame que teve resultado negativo, isto é, comprovou-se que ele não era o pai da criança. 